\title{
Repasos solemnes y lecciones ordinarias. Textos manuscritos sobre la Sagrada Escritura (1536-1539). Conclusión. Texto en latín ${ }^{1}$
}

\author{
Domingo De Soto O.P. \\ IGNACIO JERICÓ BERMEJO
}

Fecha de recepción: Septiembre 2017.

Fecha de aprobación: Septiembre 2018.

\section{Palabras clave:}

Artículo de fe, canon sagrado, Domingo de Soto, lección (pre-lección), manuscritos, reforma de la Iglesia, repaso solemne (re-lección).
Solemne revisions and ordinary lessons. Handwritten texts on Sacred Scripture (1536-1539).

\section{Keywords:}

Article of faith, sacred canon, Domingo de Soto, ordinary lesson (pre-lectio), manuscripts, reform of the Church, solemn revisión (relection).

\footnotetext{
${ }^{1}$ Como ya se comentó en ATG 82 (2019), en esta tercera parte, publicamos las conclusiones del trabajo que comenzó a publicarse en ATG 81 (2018) y el texto íntegro en latín de las re-lectiones y de la prae-lectio.

${ }^{2}$ Investigador.UniversidaddeNavarra-Peralta(Navarra). https://orcid.org/0000-0002-8524-8261.
} 


\section{Conclusión. Domingo de Soto y los nuevos artículos de fe (s. XVI) ${ }^{3}$}

Los salmantinos del siglo XVI se ocuparon celosamente de la problemática del artículo de fe ${ }^{4}$. Domingo de Soto $(1495-1560)^{5}$ no fue excepción al respecto. Enseñó teología desde la cátedra de Vísperas de la Universidad de Salamanca entre 1532 y 1552, pasando luego a la de Prima donde enseñó desde 1552 hasta su muerte (1560). Aunque no es el mayor teólogo de su tiempo, nadie ha destacado tan bien como él en los movimientos intelectuales que marcan el desarrollo teológico en los primeros sesenta años del siglo $\mathrm{XVI}^{6}$.

${ }^{3}$ Esta parte titulada conclusión, corresponde a mi contribución a mi profesor, así lo llamo siempre, en su paso a los 75 años a la condición de profesor emérito en la Universidad Gregoriana de Roma. Apareció en 2003: Domingo de Soto y los nuevos artículos de fe [V. L. Benavent y L. Morali (Ed.). Sentire cum Ecclesia. Homenaje al Padre Karl Josef Becker S. J. (Valencia, Ed. Primolibro, 2003): 49-72].

He pensado que viene muy oportuno el mismo en este trabajo como una especie de conclusión. Sobre todo, lo juzgo adecuado para conocer lo que expuso Soto en 1539 sobre el artículo décimo de la cuestión primera de la Secunda Secundae, que es al fin y al cabo el cuadro en el que se sitúan sus re-lecciones de 1536-1938, sobre la Sagrada Escritura.

Aparecieron en el mismo algunas pequeñas erratas o imprecisiones que ahora corrijo. Y me atrevo a mejorar un poco por claridad lo publicado en el cuerpo del texto. Es lo que aparece en el mismo entre corchetes. Asimismo, han pasado ya más de cuatro años y he añadido un párrafo en el epílogo final que hago notar con los consabidos corchetes. Una advertencia, las notas latinas las he dejado como aparecen en la publicación de 2003. Me ha parecido mejor así. Hay alguna diferencia ciertamente con el texto, tanto de Ott. lat. 782 como de Ms. 940. Pero el texto que hoy acepto es el que se publica en esta obra.

Dejo también la forma de citar aquí en las notas como apareció en 2003.

${ }^{4}$ Gracias al P. Becker estudié la problemática del artículo de fe en la Escuela de Salamanca. Muchas son mis publicaciones al respecto. Espero editar más. Si se desea información sobre mi trabajo, cfr.: De articulus fidei hacia dogma fidei. El camino entre la doctrina y verdad de fe católicas en la Escuela de Salamanca (1526-1584) (Vitoria, 1981); Fray Luis de León. La teología sobre el artículo y el dogma de fe (Madrid, 1997).

${ }^{5}$ Biografía. Cfr. V. Beltrán de Heredia, Domingo de Soto. Estudio biográfico documentado (Salamanca, 1960); Idem, "Soto, Dominique de", Dictionnaire de Théologie Catholique 14/2 (París, 1941): 2423-2428; F. Ehrle (J. M. March), "Los manuscritos vaticanos de los teólogos salmantinos del siglo XVI. De Vitoria hasta Báñez", Estudios Eclesiásticos 8 (1926): 289-301; G. Fraile, "Soto, Domingo de", Diccionario de Historia Eclesiástica de España 4 (Madrid, 1975): 2507-2503; M. García Miralles, "Soto, Domingo de", Gran Enciclopedia Rialp 21 (Madrid, 1975): 637-638; C. Pozo, "Soto, Domingo de", Lexikonfor Theologie und Kirche 9 (Freiburg im Breisgau, 1964): 897-898; F. Domínguez, "Soto, Domingo de", Lexikon for Theologie und Kirche 9 (Freiburg im Breisgau, 2000): 745, 746.

6 "Domingo de Soto ist nicht der grosste Theologe seiner Zeit. Aber niemand hat wohl wie er in all den geistigen Bewegungen gestanden, die in der ersten 60 Jahren seines Jahrhunderts die theologische Entwicklung priigten". K. J. Becker, Die Rechtfertigunslehre nach Domingo de Soto (Roma, 1964): 1. 
Ciertamente, la exposición de Soto sobre el artículo de fe es una verdadera joya ${ }^{7}$. Fue en 1537 cuando, en su De sacro canone et eius sensibus, dijo que se redactaron nuevos artículos en la Iglesia para salir al paso de los herejes y que, por eso, se redactó en el concilio primero de Nicea (1525) el de la consubstancialidad del Hijo con el Padre, añadiendo que, si surgen hoy nuevas herejías, no entiende por qué no ha de poder la Iglesia redactar nuevos artículos. Al respecto, sugirió que podría redactarse en el concilio venidero como artículo que Cristo se halla realmente en el sacramento de la Eucaristía, saliendo así al paso de esos herejes que lo niegan ${ }^{8}$. Existe cierta controversia sobre qué fue la Escuela de Salamanca y quién pertenece a ella ${ }^{9}$. Todos tienen a Soto como un genuino salmantino del siglo XVI. Fue catedrático de teología en la Universidad de Salamanca y se esforzó por ajustar sus enseñanzas a la doctrina común de Santo Tomás $(+1274)$.

La enseñanza del Aquinate sobre la problemática del artículo de fe de la Suma Teológica, ¿se corresponde de veras con la expuesta por Domingo de Soto en Salamanca? El Angélico escribió en pleno siglo XIII y dijo que los artículos de fe crecen con el pasar del tiempo ${ }^{10}$. Sostuvo además que corresponde finalmente al Sumo Pontífice la redacción del símbolo o del artículo de fe ${ }^{11}$. Estas dos aseveraciones se hacen comprensibles si se acepta que puede ser en

${ }^{7}$ De la problemática del artículo de fe en Soto me he ocupado en dos ocasiones directamente, cfr. De articulus fidei hacia dogma fidei. El camino entre la doctrina y verdad de fe católicas en la Escuela de Salamanca (1526-1584) (Vitoria, 1981): 44-58; "Condere articulum fidei et condere Sacram Scripturam. El poder eclesial según Domingo de Soto", Archivo Teológico Granadino 56 (1993): 63-130.

8 "Si propter necessitatem diversorum haereticorum in ecclesia illi articuli sunt conditi, ut puto de consubstantialitate divinarum personarum de divinitate Christi, nescio quare, si modo insurgant novas haereses, non possint condi novi articuli, ut v. g. si nunc in concilio futuro determinaretur tanquam articulus quod Christus est realiter in sacramento contra istos haereticos qui hoc negant". D. de Soto, Ms. 13. Relectio de catalogo librorum sacrae scripturae. Biblioteca del Cabildo de la catedral de Palencia, fol. 271r.

${ }^{9} \mathrm{Si}$ se desea una información al respecto sobre la expresión Escuela de Salamanca, cfr. C. Pozo, "Salmantizenser", Lexikon.für Theologie und Kirche 9 (Freiburg irn Breisgau, 1964): 268-269; L. Martínez Fernández, Sacra doctrina y progreso dogmático en los Reportata inéditos de Juan de Guevara. Dentro de la Escuela de Salamanca (Vitoria, 1967): 47-54; I. Jericó Bermejo, De Articulus fidei hacia Dogma fidei. El camino entre la doctrina y verdad deje católicas en la Escuela de Salamanca (1526-1584) (Vitoria, 1981): 1-5; J. Barrientos García, "La Escuela de Salamanca: desarrollo y caracteres", La Ciudad de Dios 208 (1995): 1041-1079; F. Domínguez, "Salamanca. Theologiegeschichtlich", Lexikon jür Theologie und Kirche 8 (Freiburg im Breisgau, 1999): 1476; J. Belda Plans, "Hacia una noción crítica de la Escuela de Salamanca", Scripta Theologica 31 (1999): 367-411; Idem, La Escuela de Salamanca (Madrid, 2000).

${ }^{10}$ Cfr. II-II, q. 1, a. 6c.

${ }^{11}$ Cfr. II-II, q. 1, a. 10e. 
el futuro necesaria la redacción de un nuevo artículo de fe. Precisamente, si esto ocurriera, la determinación debería ser hecha por el Papa. Soto dice que no se preocupó Santo Tomás en distinguir aquí entre el Papa y el concilio. Le bastó con decir que la Iglesia es capaz de determinar un artícolo ${ }^{12}$. Ciertamente, tiene el Papa la misma autoridad para redactar un artículo que el concilio y esto fue lo que pretendió decir en el siglo XIII Santo Tomás. Así lo declara también Cayetano (+1534), incluso en el caso de que fuera el concilio superior al Papa. Santo Tomás recuerda estas palabras: "Yo he rogado por ti para que no desfallezca tu fe, y tú, una vez convertido, confirma a tus hermanos" (Lc 22,32). Confirmar a los hermanos es hacerlos seguros en las dudas de fe. Cristo dijo a San Pedro: “Apacienta mis ovejas". El oficio principalísimo del pastor es instruir sobre lo que entraña la fe $(\mathrm{Jn} 21,17)^{13}$.

Este trabajo se ocupa sobre los nuevos artículos de fe. La enseñanza de Soto versa sobre sus comentarios a la Secunda Secundae de Santo Tomás (q. 1, a. 6-10 y q. 5, a. 3). El propio Soto califica la cuestión de gravísima. Los herejes del siglo XVI no aceptan artículo nuevo alguno. Tampoco reina unanimidad al respecto entre los católicos. Al nuevo artículo de fe aludió Soto en su relección De sacro canone et eius sensibus, tenida en $1536^{14}$. Aquí se trabajará sobre sus lecciones ordinarias o prelecciones del año 1539. Se hallan recogidas en el ms. Ott. lat. 782 de la Biblioteca Vaticana de Roma, al cual se le llamará aquí $\mathrm{R}$ [en este epílogo]. Es un manuscrito que fue corregido personalmente por Soto y se recogen en él parte de lo enseñado en 1539; pero se han añadido desde entonces algunas cosas. Se utilizará también el ms. 940 de la Biblioteca Nacional de México, al que se le llamará aquí M [en el epílogo]. Recoge una lectura ordinaria de Soto. No tiene fecha. Según K. Becker, el copista tuvo ante sí las lecciones ordinarias de Soto de $1538-1540^{15}$. ¿Refleja

12 "Pro nunc dicimus primo quod s. Thomas non est sollicitus in praesentiarum facere distinctionem inter paparn et concilium, sed satis est quod ecclesia potest est determinare articulum". R 67r $(\mathrm{I}, 10) . \mathrm{R}=$ Ott. lat. 782, In II-II. A continuación, sigue el folio correspondiente y, entre paréntesis, la cuestión (número romano) y el artículo (número arábigo).

13 "Dicimus secundo quod papa habet eandem auctoritatem condendi articulum sicut concilium, et hoc praetendit s. Thomas, ut etiarn declarat dominus Caietanus, etiarn si conciliurn esset supra paparn. [...] Et illud quod citat s. Thornas: Ego rogaba pro te et tu aliquando conversus confirma fratres tu os. Et certe confirmare fratres est securos facere de dubiis fidei. Et illud loann. 21. Pasee oves meas. Et potissirnum officium pastoris est instruere in fidern". R $67 \mathrm{r}-67 \mathrm{v}$ $(\mathrm{I}, 10)$.

14 "Haec questio est gravissima et habet difficultatem adversus haereticos et inter nonnullos catholicos. Latius nos illa tractavimus in relectione mea de auctoritate sacrae scripturae. Repetam nonnulla quae illic diximus et adiciam alia". R 66r $(\mathrm{I}, 10)$.

${ }^{15}$ Sobre la descripción, fecha y contenido de estos manuscritos, cfr. K. J. Becker, "Tradición manuscrita de las prelecciones de Domingo de Soto", Archivo Teológico Granadino 29 (1966): 131-137; 
otra explicación de Soto en Salamanca? ¿Corresponde a la de Soto en la cátedra de Prima? En el curso de 1547-1548 se impartió esa materia [In 11-II, q. 1, a. 10] desde la cátedra de Vísperas y [este trabajo] lo hizo como sustituto Diego de Chaves (cf. Ott. lat. 1051) ${ }^{16}$. Tocaba ciertamente hablar del artículo de fe en el curso 1559-1560 desde la cátedra de Prima (231*). En noviembre de 1560 moría Soto; pero se ha de recordar que, desde 1556, ya no impartía [él] clase en dicha cátedra. A petición suya había sido nombrado oficialmente por el Consejo de la Universidad un sustituto especial: Ambrosio de Salazar. Soto conservó pese a su retirada en propiedad hasta su muerte en 1560 la cátedra de Prima ${ }^{17}$. El manuscrito de Roma y el de México corresponden casi con total seguridad a lo explicado por Soto desde la cátedra de Vísperas durante el curso $1538-1539$.

\section{La novedad del artículo}

El objeto formal de la fe es la primera verdad y ésta es una sola. El objeto material es lo que está contenido en la Sagrada Escritura. Lo que se ha de creer debe distinguirse por artículos concretos. Si hay una dificultad especial para creer una concreta proposición, es porque se está absolutamente ante un artículo. Hay entonces un artículo para la muerte de Cristo y hay otro distinto para su resurrección. Si no hay dificultad especial y se cree con facilidad una cosa desde otra, se trata del mismo artículo. Es el mismo artículo que Cristo

153-154; 163; I. Jericó Bermejo, De articulus fidei hacia dogma fidei. El camino entre la doctrina y verdad de fe católicas en la Escuela de Salamanca (1526-1584) (Vitoria, 1981): 17-21.

${ }^{16}$ I. Jericó Bermejo, "Doctrina fidei catholica”, Scriptorium Victoriense 31 (1984): 242-245. (312*) Antes de comenzar el inicio del curso de 1560-1561 moría el sustituto de Soto: Ambrosio de Salazar. Aquel curso debía comenzar por el comentario de la cuestión primera de la Secunda Secundae. Lo impartió el nuevo sustituto: Juan de la Peña. Su exposición se halla contenida en dos manuscritos: Ott. lat. 1046, de la Biblioteca Apostólica Vaticana de Roma, y T 19, de la Biblioteca General de la Universidad de Coimbra. Cfr. I. Jericó Bermejo, La Escuela de Salamanca del siglo XVI. Una pequeña introducción (Madrid 2005): 206-211. Esta nota aparece con un asterisco y, en el cuerpo del texto, entre paréntesis. Es que es nueva respecto a este artículo editado en 2003.

17 "Cuando, poco después, al año siguiente [1552], por haber sido elevado Cano a la dignidad episcopal, quedó vacante definitivamente la cátedra de Prima, fue Soto solicitado por el Consejo de la Universidad, de acuerdo con el voto de los alumnos, para que la desempeñara por lo menos en los cuatro años siguientes; pasados los cuales se le concederían todos los privilegios de los jubilados. Aceptó tan honrosa solicitud y tomó con alegría la enseñanza. Transcurridos los cuatro años, en 1556 nombraron a Ambrosio de Salazar para sustituirle en la cátedra, y los suyos le eligieron de nuevo Prior. En este puesto falleció el 15 de octubre de 1560". F. Ehrle (J. M. March), "Los manuscritos vaticanos de los teólogos salmantinos del siglo XVI. De Vitoria a Báñez”, Estudios Eclesiásticos 30 (1929): 300-301. 
padeció, murió y fue sepultado. Tal es la doctrina de Santo Tomás ${ }^{18}$. Soto dice que va a tomar el término artículo para significar una proposición especial en la fe. Son estas sentencias o artículos como los miembros de la fe. Se ajustan entre $\operatorname{si}^{19}$.

¿De qué artículos habla Santo Tomás cuando los llama verdades especialmente difíciles de creer? Está haciendo referencia a los viejos artículos; es decir, a los expresados en el (símbolo) Apostólico. De ellos habla cuando dice que los artículos de la fe se distinguen en conformidad con las tres Personas íntimas de la Trinidad, colocándose del Padre uno solo (por supuesto, en el Apostólico), siguiendo a continuación seis sobre el Hijo y viniendo luego cinco sobre el Espíritu Santo. Este mismo orden es guardado en el (símbolo) Nicenoconstantinopolitano, al que suele llamar Soto simplemente el Niceno. Éste se distingue solo del Apostólico por ofrecer algunas partecitas añadidas contra los herejes. Del (símbolo) de San Atanasio dirá Soto que no posee el mismo una autoridad tan grande como el Apostólico. Ya existían estos tres símbolos cuando distinguieron diversamente los teólogos los artículos. Separaron siete correspondientes a la divinidad y siete pertenecientes a la humanidad ${ }^{20}$.

¿De qué artículos trata Soto en su exposición? Habla de todos. Hay momentos en los que se refiere a los viejos. Así se llama aquí a los presentes expresamente en el Apostólico. Estos artículos viejos son esas verdades especialmente difíciles que todos han de saber por quedar obligados a creerlas expresamente; es decir, dándose cuenta de lo que creen. Y [se llama también de esta forma] a los nuevos (presentes expresamente en el Nicenoconstanti-

18 "Postquam habemus quod obiectum formale fidei est una prima veritas et obiecta materialia sunt omnia quae sunt contenta in sacra scriptura, quaeritur an ista credibilia sint distinguenda per certos artículos. Et s. Thomas facit duo. Primum declarat nomen articuli [...]. Deinde ponit duas conclusiones. Quotiescumque est specialis difficultas credendi aliquam propositionem, illa per se est unus articulus, ut alius est articulus de morte Christi et alius est de resurrectione. $2^{\text {a }}$. conclusio. Quando non est specialis difficultas sed facile creditur unum per aliud, tune est idem articulus, ut idem est articulus quod Christus passus est et mortuus et sepultus". R 65r $(I, 6)$.

19 "Quidquid sit de nomine, articulus transfertur in proposito ad significandum specialem propositionem fidei, nam istae propositiones sunt sicut membra fidei, quae coaptantur ad invicem". $\mathrm{R}$ $65 \mathrm{r}(\mathrm{I}, 6)$.

20 "Et articuli distinguuntur tripliciter secundum sunt tres personae intimae. Et de Patre solum ponitur prmus articulus. Statim sequuntur 6. articuli de Filio. Quinque postea sunt de Spiritu Sancto. In concilio nicaeno idem ordo servatur et solum distinguitur a symbolo apostolorum quia adduntur aliquae prticulae propter haereses. Sed symbolum Athanasü non est tantae auctoritatis sicut apoostolorum. Postea tamen distincti sunt aliter articuli fide a theologis in 7. pertinentes ad divinitatem, et 7 . ad humanitatem". M 14v (I,9).

M=Ms. 940, In II-II.

A continuación, sigue el folio correspondiente y, entre paréntesis, la cuestión (número romano) y el artículo (número arábigo). 
nopolitano). Habla sobre todo Soto de los nuevos. Así se llama aquí a esas verdades que no son de suyo especialmente difíciles a la hora de creer, pero que todos han de creer expresamente porque la Iglesia las ha impuesto a todos los cristianos para contrarrestar las herejías. Tales son algunas sentencias colocadas en el Nicenoconstantinopolitano, concretamente las referidas a que el Hijo es verdadero Dios y a que el Espíritu Santo es también verdadero Dios. A los viejos y a los nuevos les une una misma razón. Han de ser sabidos por ordenar la Iglesia que se crean expresamente; es decir, que se crean conociendo expresamente lo que se cree. Ante todo, le interesa a Soto hablar de los nuevos artículos de fe; pero, ¿es que pueden decirse artículos nuevos los colocados en el siglo IV en el Nicenoconstantinopolitano? ¿Son de veras artículos de fe?

Son los artículos de la fe: las verdades especialmente difíciles, la plenitud y perfección del desarrollo de la sustancia de la fe por el tiempo. La fe entera se concentra perfectamente en cuanto a la sustancia en dos verdades: existencia y remuneración divinas (cfr. Heb 11,6). Las mismas fueron conocidas desde el principio. Con el paso del tiempo y gracias a la revelación progresiva de Dios es como esa sustancia se desarrolla o despliega. No crece sustancialmente; pero aumenta por explicación. Con toda seguridad el momento culminante del desarrollo, y ya no hay más, ocurre con la predicación de Cristo a los Apóstoles. Éstos la entregaron toda a la Iglesia. Los artículos viejos de fe son esas verdades, o principios (por eso, se les llama principales), en las que queda esencial y plenamente explicada la fe. Dios reveló todo para que lo creyeran los hombres; pero no es necesario saber todas y cada una de las verdades reveladas por Cristo. Basta con saber y creer expresamente las principales: los artículos. Quien las conoce y las cree sabiéndolas asiente de hecho (implícitamente) a toda la revelación divina realizada a través del paso del tiempo. Por supuesto, la entera revelación divina que todos han de creer (por consiguiente, también los artículos) se encuentra contenida en la Sagrada Escritura.

Cuando se afirma que la Iglesia es capaz de redactar un nuevo artículo de fe después de haber muerto los Apóstoles, se supone espontáneamente que ese artículo nuevo redactado por la Iglesia tiene que ser igual totalmente a los expresados en el Apostólico; es decir, que ha de ser una verdad especialmente difícil de creer, un verdadero principio. Así las cosas, se piensa que crece todavía después de Cristo y los Apóstoles la fe en cuanto a la explicación, con lo cual habría que negar que la plenitud del desarrollo de la fe en cuanto a la explicación acaecida en la venida de Cristo. En este supuesto, no cabe otra salida que decir que el nuevo artículo de fe exige que reciba la Iglesia una revelación nueva y distinta de la entregada por los Apóstoles. La necesidad de una revelación nueva para poder hablar de la redacción de un artículo nuevo es rechazada de lleno por Soto. Puede redactarse un artículo nuevo sin produ- 
cirse revelación nueva alguna; es decir, sin que crezca ulteriormente por explicación la fe. Juzga intolerable que haya que esperar una revelación para salir de ciertas dudas en la fe que se producen por el paso del tiempo de la Iglesia .

Si fuera necesaria tal revelación nueva, debería hacerse [ella] a cada una de las personas en duda o, en caso contrario, debería hacerse al menos a una sola que, a su vez, la expusiera a las demás. Sería absurdo y fatuo decir que cada uno de los que dudaran sobre la fe habían de esperar una revelación especial. Asimismo, habría de ser muy cierto y de fe que no pudiera engañar a los demás la persona a la que se le hiciera la revelación en exclusiva. Si no fuera esto muy cierto, aparecerían incluso las dudas de si decía la verdad, produciéndose cismas entre los hombres en contra de lo mandado por San Pablo (cfr. 1 Cor 1,10). Si fuera de fe que esa persona es incapaz de engañar a los demás, no podría ser otro que el Papa o el concilio. Desde este punto de vista se estaría reconociendo que no hay razón para dudar de lo capaz que es la Iglesia de determinar algo como de $\mathrm{fe}^{21}$. No se precisa revelación ulterior alguna porque, con la redacción de un nuevo artículo, no aumenta por explicación la fe.

Aquí aparece la diferencia entre los artículos viejos y los nuevos. Éstos no son verdades especialmente difíciles y, entonces, no son enteramente iguales a los artículos viejos. Hay cierta identidad en cuanto han de creerse como los artículos viejos; es decir, expresamente. Para Soto, consiste la potestad de redactar un artículo nuevo de fe no supone recibir una revelación nueva. No se precisan revelaciones nuevas, que se añadan a la Escritura Canónica. Mientras los Apóstoles y los profetas fueron iluminados inmediatamente por Dios y recibieron un conocimiento interior, no ocurre esto ya en la Iglesia, se trate del concilio entero o del Papa. Es verdad que la Iglesia queda ciertamente iluminada por Dios en la redacción de un artículo en el sentido de que no se le ha de permitir errar al consultar diligentemente la Sagrada Escritura, comparar un pasaje con otro y utilizar las razones naturales para determinar algo como pertinente de hecho a las costumbres o a la fe. Si quisiera la Iglesia al redactar un artículo esperar que se produjera una revelación inmediatamente de Dios,

21 "Sed respondent haeretici illud non esse necessarium, sed quando esset dubium expectanda esset revelatio a Deo inmediate. Sed arguitur quod hoc est intollerabile. Nam si emergente dubio est expectanda revelatio, vel illa revelatio deberet fieri singulis personis dubitantibus vel deberet fieri uní qui enuntiaret aliis. Primum esset absurdum et fatuum dicere, puta quod singuli qui dubitarent deberent expectare revelationem specialem. Et si detur secundum, tune est argumentum quía, vel esset certissimum et de fide quod ille cui fieret revelatio posset nos decipere vel non. Si non esset certissimum, tune adhuc semper maneremus dubii an ille diceret nobis verum, et tune essent schismata ínter homines contra praeceptum Pauli 1 ae. ad Corinth. 1. Si autem esset de fide quod ille non potest nos decipere, certe non potest ille esse alius nisi papa vel concilium. Et sic non est dubitandum quin ecclesia possit determinare aliquid tanquam de fide". R 66r (I,10). 
se equivocaría ${ }^{22}$. Lo redactado como nuevo no es tal. Lo transmitieron ya expresamente los Apóstoles. Se halla en la Sagrada Escritura.

¿Saben de veras todos los cristianos llegados a la edad de la discreción la verdad de la presencia real de Cristo en la Eucaristía, la cual no es artículo; pero Soto dijo que podría serlo? Ciertamente, no está el de la presencia real expresado en el símbolo. No se habla allí expresamente de que, en el Sacramento del Altar, se halla realmente presente el cuerpo de Cristo; pero esto no obsta para que estén ya obligados todos los cristianos llegados a la edad de la discreción a creerlo expresamente. Es algo que fue determinado por la Iglesia contra Berengario $(+1088)$; pero, además, lo propone la Iglesia para ser creído cuando celebra la fiesta del Corpus Christi. Tienen ciertamente todos los cristianos que recibir la Eucaristía cada año ${ }^{23}$. La afirmación de Santo Tomás de que los artículos de la fe crecen con el paso del tiempo, ¿no haría referencia solo al tiempo anterior a la llegada de Cristo? ¿Por qué son precisos los artículos nuevos? Se pasa al derecho desde el hecho. La Iglesia ya ha redactado nuevos artículos en el siglo IV. Pueden entonces crecer también con el pasar del tiempo para poner término a las herejías nuevas que surgen ${ }^{24}$.

El artículo nuevo se redacta precisamente después de la muerte de los Apóstoles porque empieza a producirse oscuridad sobre lo realmente transmitido por los Doce con claridad. Esta oscuridad da lugar a las herejías y éstas lo embrollan todo con la consiguiente confusión. Lo claro se vuelve oscuro con el paso de los años. No se puede permitir que se oscurezca o se tergiverse la fe recibida de los Apóstoles. Santo Tomás habla de que la fe creció por la sucesión del tiempo. Así, cuanto más accedían los hombres a Cristo, quedaban más iluminados y conocían más de Cristo. Por eso se dijo que no había surgido nadie mayor que Juan el Bautista (cfr. Mt 11,11). Esto se cumple ciertamente en los que precedieron a Cristo; pero las cosas cambian después de la pasión.

22 "Quae est ista potestas ecclesiae ad condendum articulum fidei. Utrum condere articulum sit recipere novam revelationem sicut apostoli vel prophetae receperunt novas revelationes scripturae canonicae. Breviter sine argumentis respondetur quod non, nam apostoli et prophetae inmediate illuminabantur a Deo, itaque recipiebant cognitionem interiorem inmediate a Deo. Ecclesia vero non, nec totum concilium nec papa, sed isto modo illuminatur quod, si ecclesia conculat sacram scripturam diligenter et conferat unum locum cum alio et utatur etiam rationibus naturalibus ad determinandum aliquid sive pertinens ad mores sive ad fidem, non permittitur errare. Sed tamen si velit ecclesia expectare revelationem inmediate a Deo ut dicit Ubicleft, tune erraret”. R 66r $(\mathrm{I}, 10)$.

23 “' 2 . Conclusio. Quantum ad sacramentum altaris dato quod non sit articulus expressus in symbolo quod illic est corpus Christi, tenentur credere omnes expresse. Probatur quia est detenninatum $\mathrm{ab}$ ecclesia contra Berengarium et est propositum ecclesiae ut credatur cum ecclesia celebrat festum de corpore Christi. Itero quia tenemur accipere eucharistiam in anno". M 15v (I,9).

24 “Articuli possunt crescere successione temporis ad dirimendas novas haereses". R 66r (I,10). 
A partir de entonces se conoce más cuanto más cerca se está de Cristo ${ }^{25}$. Simplemente, las cosas se ven mejor de cerca que de lejos. Con el paso del tiempo, se pierde claridad. ¿Cómo se remedia esta posible tergiversación y oscuridad? En el siglo IV crecía la oscuridad en torno a una verdad concreta transmitida claramente por los Doce. Reaccionaron los cristianos con los concilios de Nicea y de Constantinopla. Allí se establecieron dos nuevos artículos de la fe: que el Hijo es Dios verdadero y que lo es también el Espíritu Santo.

De estos datos de la historia se deduce que puede la Iglesia redactar un artículo de fe y que la misma es capaz de obligar a los cristianos a creer lo redactado como las Sagradas Escrituras. No se está hablando aquí únicamente de la Iglesia antigua de los Apóstoles sino de la actual. En el concilio primero de Nicea no había apóstol alguno. Hay hoy tanta autoridad en la Iglesia como la hubo en el concilio de Nicea ${ }^{26}$. San Pablo habló de lo necesaria que era una sola fe y un solo bautismo (cf. Ef 4,5). Lo que creen los cristianos ha de ser uno en todos en cuanto a la explicación; es decir, han de sentir todos lo mismo (cf. Rom 12, 16). Precisamente, para que se diera la misma fe, fue por lo que fue preciso explicar (en el sentido de poner de nuevo claridad) algunos artículos en los que todos comulgaran. Se habla precisamente por ello de fe católica; es decir, fe universal. Boecio (+524) la llama así por haber sido predicada en todo el mundo; pero se le llama quizás así porque todos tienen obligación de creerla $^{27}$.

25 "Est dubium quomodo creverit ista fides. S. Thomas dicit quod per successionem temporis, quia quantum homines magis accedebant ad Christum tanto erant magis illuminati et plus de Christo cognoscebant. Et ideo dixit Christus de Ioanne Baptista: Non surrexit maior, etc., ubi locutus est Dominus respectu praeteritorum. Sed post passionem Christi quanto propinquiores fuerunt, tanto magis cognoscebant". M 14r $(\mathrm{I}, 9)$.

26 "Et sic habemus quod ecclesia potest [condere articulum fidei et obligare nos ad credendum sicut sacrae scripturae. Et non solum ecclesia antiqua apoostolorum sed ecclesia quae modo est. Nam in concilio nicaeno iam non erat apostolus, et tantam auctoritatem modo sicut concilium nicaenum]". R $67 \mathrm{r}(\mathrm{I}, 10)$.

27 "Item quia ut dicit apoostolus ad Eph. 4., est una fides et unum baptisma. Ille intelligit quod illud quod credimus sit unum apud omnes quoad explicationem, id est adeo $1^{\circ}$. quod simus id ipsum sentientes. Et sic necesse fuit explicare aliquos articulos in quibus omnes communicemus et inde vocatur fides catholica, id est universalis fides. Et Boethius in 3. lib. de Trinitate hoc dicit: quia praedicata est in universo mundo. Sed forsan sic vocata quia ab omnibus est credenda”. M 14r (I,9). 


\section{El origen en la Sagrada Escritura}

En Nicea (325) y en Constantinopla (381) fueron determinados dos nuevos artículos de fe desde la Sagrada Escritura. Cuando se habla del artículo como verdad expresa, quiere señalarse que ha de saberse o creerse expresamente. ¿Es el artículo también verdad manifiesta o expresa de la Sagrada Escritura? Es preciso creer la revelación de la Biblia; pero no está toda necesariamente expresa allí. Hay realidades que no están manifiesta o expresamente sino en el interior o implícitamente. El término del artículo de Nicea: homousios, se tomó ciertamente de la Sagrada Escritura; pero no es un término manifiesto o expreso en ella. El nuevo artículo es verdad expresa en cuanto al creer; peor no está siempre expresamente en la Sagrada Escritura. No tiene entonces que ser necesariamente el artículo una verdad expresa de la Biblia. La virginidad perpetua de María (que todos los cristianos confiesan en el Apostólico) no se halla expresamente en la Sagrada Escritura y es artículo de fe ${ }^{28}$. Tampoco ha de decirse que es artículo el que no estuvo explícitamente en la Sagrada Escritura, como la virginidad perpetua de María. Hace Soto esta afirmación porque hay autores que hablan así también ${ }^{29}$.

Según referencia del Waldense (Tomas Netter, +1431) sostuvo Juan Wiclef $(+1384)$ que la Iglesia toda no tiene [la] autoridad de determinar algo como de fe si lo que redacta no está expresado en la Sagrada Escritura ${ }^{30}$. Wiclef se opondrá entonces a lo realizado en Nicea ya que el homousios no se halla expresado en la Biblia. Wiclef parece decir que la redacción de un nuevo artículo es una operación sencilla de verdad: se toma una sentencia de la Sagrada Escritura y se afirma que es artículo de fe. ¿En que consiste la potestad de la Iglesia de redactar un nuevo artículo de fe? No es la capacidad de recibir una revelación. Cuando la Iglesia redacta un artículo de fe, recibe ciertamente una revelación; pero le viene la misma de modo mediato (desde la Sagrada Escritura). Tiene la Iglesia potestad para extraer una proposición desde la Biblia; pero su autoridad se basa en la imposibilidad de equivocarse al examinar las Escrituras Sagradas para determinar un artículo ${ }^{31}$. Wiclef parece oponer-

28 "Solum nota ad lum. quae requiruntur ad articulum fidei. Quia certe non requiritur sit propositio expressa in sacra scriptura, quia quod beata virgo sit semper virgo non est expresse in sacra scriptura et tamen est articulus fidei”. M 13r $(\mathrm{I}, 6)$.

29 "Non sufficit dicere quod est articulus qui non fuit in scriptura explicite sicut de virginitate perpetua beatae virginis quia de hoc etiam sunt auctores". M 13r (I,9).

30 "Ubicleft [ut recitat Ubaldensis to. $1^{\circ}$. lib. $2^{\circ}$. cap. 19.] dicit quod tota ecclesia non habet auctoritatem determinandi aliquid tamquam de fide nisi expressum sit in sacra scriptura". M 16r (I,9).

31 " 2 um. dubium. Quae potestas est ista condendi articulum fidei, scilicet an condere articulum sit recipere novam revelationem a Deo inmediate. Respondetur quod non recipit revelationem eccle- 
se porque entiende que la Iglesia toda puede equivocarse al redactar. ¿Niega Soto absolutamente la equivocación? Da la razón a Wiclef cuando dice que la Iglesia podría equivocarse si esperara una revelación divina nueva y, desde la supuesta recepción, definiera ${ }^{32}$ o si quisiera determinar algo sin examinar la Escritura $^{33}$. ¿Cómo se obtiene la certidumbre de que no se equivocaron los padres en el concilio primero de Nicea al determinar la fe? ¿Hicieron ciertamente todo lo que debían? ¿Examinaron con diligencia las Escrituras? Los cristianos tienen la certidumbre de que no se ha de permitir que la Iglesia determine algo si no ha puesto previamente lo que debe; es decir, la diligencia suficiente ${ }^{34}$. ¿Se asigna entonces alguna dignidad a la Iglesia cuando no se permite errar a persona alguna singular que hace diligentemente lo que debe? Esto es inadmisible y falso. Una vieja o un teólogo doctor incluso hacen todo lo posible y, pese a ello, pueden equivocarse con ignorancia invencible. Es esto lo no puede darse en la Iglesia. Es imposible que ésta se equivoque en la fe con ignorancia invencible ${ }^{35}$. Lo redactado por la Iglesia como artículo de fe, ¿se halla de veras en la Sagrada Escritura, pudiendo además probarse? Ciertas pruebas desde la Sagrada Escritura se aceptan unánimemente en el siglo XVI por constar clara su verdad desde las sentencias del Apostólico; es decir, se puede decir que no se duda de que está en la Biblia porque se acepta que está en el símbolo breve. Es el caso de la verdad de la perpetua virginidad de María. Desde la Escritura, ¿se puede probar que el Hijo es verdadero Dios como lo es el Padre? Esta pregunta se formula porque, en el siglo XVI, hay todavía algunos con la convicción de que lo redactado en Nicea no se halla en el Apostólico. Soto tiene esta convicción como un error, señalando que se halla en el Apostólico,

sia quando condit articulum fidei sed solum mediate, scilicet habet potestatem eliciendi ex scriptura aliquam propositionem. In hoc consistit auctoritas ecclesiae: quod, si scrutetur scripturas ad determinationem articuli, non possit errare. Tamen si ecclesia vellit aliquid determinare sine scrutatione scripturae, errabit". M 16v (I,10).

32 "Sed tamen si velit ecclesia expectare revelationem inmediate a Deo ut dicit Ubicleft, tune erraret". R 66r $(\mathrm{I}, 10)$.

33 "'Tamen si ecclesia vellit aliquid determinare sine scrutatione scripturae, errabit". M 16v $(\mathrm{I}, 10)$.

34 "Sed tune est dubium quomodo sumus certi quod non errat, puta quod non erraverunt patres concilli nicaeni in detenninatione fidei. Forsan non egerunt totum quod in se erat, nec diligenter perscrutati sunt scripturas. Respondetur. Sumus certi quod non perrnittetur ecclesiam determinare aliquid nisi fecerit quantum in se est: sufficientem diligentiam". R 66r-66v (I,10).

35 "Sed tune est dubium quía nullam dignitatem attribuimus in boc ecclesiae, nam nulli singulari personae facienti quod est in se diligenter permittetur errare. Respondetur hoc esse falsum, nam stat quod vetula, iJnrno doctor theologus, faciat quantum potest et nihilominus erret licet ignorantia esset tune invincibilis. Sed ecclesia non potest errare nec per ignorantiam invincibilem in bis quae sunt fidei”. R 66v (I,10). 
incluso expresamente, que Cristo era Dios. Cuando se dice Creo en Dios, se está haciendo todas las tres personas ${ }^{36}$. Por supuesto, redactar un artículo no es redactar la Sagrada Escritura. La Iglesia no puede redactar la Sagrada Escritura al necesitar para hacerlo una revelación nueva ${ }^{37}$. De todas formas, han de estar los cristianos ciertos de que no ha de fallar la fe en la Iglesia ${ }^{38}$. Así lo asegura la promesa divina. Ciertamente, no se ha de equivocar al definir. En consecuencia, todos los cristianos no creen lo que es falso como verdadero. Cuestión certísima y de fe es que la Iglesia posee autoridad para determinar de fe, extrayendo la verdad desde la Sagrada Escritura. Obró así ya en el concilio primero de Nicea, quedando determinado [entonces] mucho de fe que no era preciso tener antes expresamente como tal; es decir, como artículo, como es el caso concreto de que Cristo es Dios consustancial con el Padre ${ }^{39}$.

La forma como se procedió en Nicea es coherente con la autoridad de la Sagrada Escritura al mostrar ésta que posee la Iglesia autoridad para determinar de fe: "Yo estoy con vosotros siempre hasta la consumación del mundo" (Tim 28,20); "Yo rogaré al Padre, y os dará otro abogado, que estará con vosotros para siempre" (Jn 14,16). Cristo y el Espíritu Santo permanecen en la Iglesia para gobernarla y, principalísimamente, para que exponga la Sagrada Escritura revelada por el Espíritu Santo ${ }^{40}$. No se precisaría esta presencia si hubiera cambiado Cristo la condición de los hombres tan clara y distintamente que no pudieran extraer sentidos diversos de unas mismas palabras. Es talla condición humana que hay tantas cabezas como sentidos. De la Biblia extra-

36 “Aliud dubium est an sit in symbolo apoostolorum quod Christus sit Deus. Quod dubium conmovemus quia adbuc sunt aliqui contra concilium nicaenum, qui determinavit quod Christus sit Deus, quod apostoli hoc non dixissent. Respondetur quod est error, immo est expresse in symbolo apoostolorum quod Christus erat Deus. Quando dicitur credo in Deum refertur ad omnes personas". M 14v-15r (I,9).

37 "Condere articulum fidei non est condere sacram scripturam, et sic tota ecclesia non potest condere sacram scripturam cum ad hoc requiratur inmediate revelatio". M 16v $(\mathrm{I}, 10)$.

38 "Sed dicetis. Unde habemus certitudinem quod ecclesia non errabit in determinatione articulorum. Respondetur quod certi sumus ex illo quod Deus promisit quod non deficiet fides ecclesiae". M 16v (I,10).

39 "Quaestio est certissima et de fide, quod ecclesia habet auctoritatem determinandi aliquid tanquam de fide eliciendo illud ex sacra scriptura. Roe patet, nam in concilio nicaeno determinata sunt multa de fide quae antea non erant expresse de fide tanquam articulus, sicut quod Christus est Deus consubstantialis Patri”. R 66r (I,10).

40 "Et confirmatur auctoritate sacrae scripturae, nam Matth. 28. Ego vobiscum sum usque ad consummationem saeculi. Et loan. 14. Ego rogaba Patrem et alium Paraclitum dabit vobis ut maneat vobiscum in aeternum. Et tarnen non erat necessarium quod Christus et Spiritus Sanctus manerent in ecclesia nisi ad gubernandum ecclesiam et potissirnum ad exponendum scripturam, quam ipse Spiritus revelaverat". R 66r (I,10). 
jo Arrío (+336) que Cristo no era Dios: "El Padre es mayor que yo" (cf. Jn 14,28). Sabelio (s. IV) dedujo en cambio de ella que el Hijo era con el Padre la misma persona: "Yo y el Padre somos una misma cosa" (cfr. Jn 10,30). Hubo de dejar Cristo en la Iglesia [entonces] la autoridad de explicar la Sagrada Escritura y que esa exposición fuera de $\mathrm{fe}^{41}$.

El Waldense se opuso frontalmente a las herejías de Wiclef. De todas formas, al hablar del artículo nuevo de fe da la impresión de decir una cosa tan admirable como que la Iglesia actual no podría ya aumentar ni explicar más artículos de fe por hallarse todos explícitos ${ }^{42}$ al haberse alcanzado la perfección en los nuevos artículos. A la fe le ocurriría como al hombre. Crece durante un tiempo; pero, una vez alcanzada la plenitud (el hombre la alcanza a los treinta años), ya no hay crecimiento posible ${ }^{43}$. En relación a las palabras del Waldense de que la Iglesia no puede ya en la actualidad redactar nuevos artículos dice Soto que han de entenderse por no ser ya conveniente hacerlo si no hubiera necesidad al ser verosímil que, en un tiempo tan largo, se hubieran puesto claramente ya todos; pero añade Soto que el Waldense no negaría que, si surgiera la necesidad, podría la Iglesia explicar ahora también un artículo nuevo ${ }^{44}$.

Consciente es Soto del prestigio del Waldense. Se redactaron nuevos artículos en la Iglesia para salir al paso de los herejes. Si surgen hoy herejías nuevas, no entiende [él] por qué no ha de poder la Iglesia redactar artículos nuevos, siendo ésta una posibilidad para el concilio venidero: que se redactara como artículo que Cristo se halla realmente en el sacramento de la Eucaristía,

41 "Et ratione probatur, nam Christus nisi mutasset conditionem hominum tam ciare et perspicue quin alii homines alios elicerent sensus ex eisdem verbis, nam haec est conditio humana ut quot capita tot sensus, sicut Arria ex illo verbo: Pater maior me est, elicuit Christum non esse Deum, et Sabelius ex illo verbo: Ego et Pater unum sumus, elicuit Filium esse eandem personam cum Patre. Ergo necessarium fuit quod Christus relinqueret in ecclesia auctoritatem explicandi sacram scripturam, ita ut illa expositio esset de fide". R 66r (I,10).

42 "Et idem videtur praetendere dominus Ubaldensis tomo 1. lib. 2. cap. 22., immo dicit unum mirabile quod ecclesia quae modo est non posset augere nec explicare piures artículos fidei quia iam omnes sunt expliciti, sicut horno qui pervenit ad perfectarn aetatem non posset amplius crescere". $\mathrm{R}$ 66v $(\mathrm{I}, 10)$.

43 "Sed contra hoc est auctoritas Ubaldensis tom. 1. lib. 2. cap. 22. ubi [...] addit: iam modo ecclesia non potest determinare quia iam venit ad perfectum numerum articulorum, sicut horno usque ad 30. annos potest crescere, non tamen ultra postquam pervenit ad plenitudinem entis “. M 18v (I,10).

44 "[Et ad illud verbum Ubaldensis, scilicet quod ecclesia iam modo non potest iam condere novos articulas, respondendum est quod intelligitur quia iam non expedit nisi erit necessitas, quia in tanto tempore verisimile est quod omnes sunt iam expliciti. Sed non negaret quin, si occurrerit necessitas, posset etiam nunc explicare novum articulum]". R 67r (I,10). 
saliendo así al paso de esos herejes que lo niegan ${ }^{45}$. El Waldense quiso al parecer decir solo que no hay necesidad ya de determinar más ampliamente los artículos de fe sin decir con ello que la Iglesia actual posea menos autoridad que la antigua. Si fuera necesario determinar un artículo de fe, podría hacerlo esta Iglesia, la cual es una (o la misma) que la existente en $\mathrm{Nicea}^{46}$.

\section{La autoridad de la Iglesia}

Los artículos viejos son verdades especialmente oscuras o difíciles de aceptar por el entendimiento. Nunca los habría conocido el hombre por sí solo. Una vez conocidos es imposible que uno los demuestre con la sola razón. Su contenido supera la capacidad natural del hombre. Los nuevos no son verdades especialmente oscuras. En este sentido no son principios; pero son principales por decir la Iglesia que han de creerse como los artículos viejos o principios propios de la fe. Una vez revelados, tiene el entendimiento solo razones suficientes para creerlos; pero esa fe es solo humana, adquirida, $u$ opinión. Uno cree entonces porque opina que es verdad. Aquí se habla de la fe infusa; es decir, de la luz sobrenatural que da Dios al hombre para que acoja la predicación exterior de la revelación divina que debe creer (cf. Rom 10,17). Todas las verdades de fe, sean principios en sentido estricto (los viejos) o sean conclusiones (los nuevos), ha de aceptarlas el cristiano. Ha de hacerlo apoyado sola y exclusivamente en Dios que revela. No debe apoyarse en prueba o razonamiento alguno. Se cree a Dios por Dios mismo. Es imposible saber lo que dice y obliga a creer Dios si no entra de por medio la Iglesia. La Escritura misma necesita que, desde el exterior, se atestigüe que contiene de veras la revelación divina. Es imposible creer con la fe infusa los artículos, viejos o nuevos, si no se atiende a la Iglesia que los señala. La razón formal de la fe es la autoridad divina. Esa autoridad aparece unida a la indicación de la Iglesia.

45 "Hoc tamen bona venia gravissimi doctoris dixerim: non video quomodo sit verum, nam si propter necessitatem diversorum haereticorum in ecclesia illi articuli sunt conditi, ut puto de consubstantialitate divinarum personarum de divinitate Christi, nescio quare, si modo insurgant novas baereses, non possint condi novi articuli, ut v. g. si nunc in concilio futuro deterrninaretur tanquam articulus quod Christus est realiter in sacramento contra istos haereticos qui hoc negant". D. de Soto, Ms. 13. Relectio de catalogo librorum sacrae scripturae. Biblioteca del Cabildo de la catedral de Palencia, fol. 271r.

46 "Respondetur quod Ubaldensis intelligit quod non est necessarium amplius determinare artículos fidei, non quod ecclesia sit minoris auctoritatis quam antiqua. Si enim opus esset determinare articulum fidei, haec ecclesia quae una est posset". M 18v (I,10). 
Los herejes todos coinciden en apartarse de la Iglesia al creer. Por esta razón, dejan la fe infusa. Se preguntó Santo Tomás si permanece en el hereje la fe infusa. Y colocó dos conclusiones. Dice en la primera que, si uno deja de creer un artículo, pierde la fe infusa. La especie del acto de fe viene de un único acto formal y, si desaparece esa razón formal, uno deja de tener fe. Se queda sin el hábito ${ }^{47}$. Como el hereje dice creer de veras algunos artículos, ha de deducirse que los cree por otro camino. Es sin embargo un hecho que no los cree por decirlos la Iglesia ${ }^{48}$. Durando de San Porciano (+1334) es el único en no compartir esta enseñanza y dice que, si un hereje deja de creer un solo artículo, sigue conservando la fe infusa, incluso así es en el caso de creer un artículo nada más ${ }^{49}$.

En contra de Durando dirá Soto que ese hereje no cree artículo alguno desde la razón formal de la fe y que, en consecuencia, ha perdido el hábito de la fe. Si asintiera a algún artículo de fe por haberlo puesto la Iglesia, asentiría por la misma razón también a todos los demás. Si asiente, lo hace entonces por otras razones. No queda ya en él por tanto la razón formal de la $\mathrm{fe}^{50}$. Si se aceptara lo expuesto por Durando, nadie podría perder la fe infusa. Si no la pierde el hereje por dejar de creer un artículo, tampoco la perdería el que negara en realidad todas las proposiciones, incluso la Escritura entera, y acogiera al menos una proposición de fe. Es algo ridículo. Podría infundirse la fe a uno que cree un solo artículo sin creer los demás. Como el hereje ha sido cristiano antes, debería reconocerse que, al incurrir en herejía, retendría la fe infusa en tal disposición y bastaría esto para que se afirmara la fe, lo cual es falso ${ }^{51}$.

${ }^{47}$ Es cierto que los diferentes actos de fe dependen de una realidad infundida por Dios. La mayoría de los teólogos llaman a esa realidad hábito. Es lo que hacen Santo Tomás y Soto.

48 "Articulus 5. Si in haeretico est fides infusa. S. Thomas ponit duas conclusiones. $1^{\text {a }}$. In haeretico si discredit uni articulo, non manet fides infusa. Probatur quia species actus provenit ex uno formali obiecto. Si ergo aufertur ratio formalis obiecti ab haeretico. Ergo habitus fidei. $2^{\mathrm{a}}$. conclusio. Quod illa quae credit haereticus credit alia via, non quia ecclesia dicit”. M 37r-37v (V,3).

49 "Solus Durandus [...] dicit quod dato quod haereticus discredit uni articulo, manet in eo fides infusa, immo si solum unum articulum credat". M 37v (V,3).

50 "Probatur conclusio contra Durandum quia iste haereticus nulli articulo credit per rationem formalem fidei. Ergo non habet habitum fidei. Antecedens probatur quia, si assentiretur alicui articulo fidei quia positus est ab ecclesia, illa ratione omnibus assentiret. Sed assentit per alias rationes. Et sic non manet in illo ratio formalis fidei”. M 37v (V,3).

51 "Item arguitur quod sequeretur secundum Durandum quod nullus possit perdere fidem infusam. Probatur quia, si haereticus non perdit ex eo quod discredit uni articulo fidei, ergo pari ratione si re neget omnes et scripturam desumpta una propositione fidei, quod est ridiculum. Ergo non est sustentabilis opinio Durandi. Item sequeretur quod possit alicui infudi fides credenti uni articulo et discredenti omnibus aliis. Probatur quia, si iste esset antea christianus, maneret cum 
Además de la unidad del hábito y de la unidad del objeto, hay en la fe también unidad de parte del medio por el que el hábito inclina a las conclusiones de fe; es decir, por ser revelación divina. Quien niega entonces la autoridad de la Iglesia niega el modo de conducirse en la $\mathrm{fe}^{52}$. El poseedor de la infusa dura más tiempo en la fe que quien no la tiene. El hereje se desliza más fácilmente al error en otro artículo. Además, no suele moverse por su herejía como los cristianos por su fe. Éstos murieron por ella y por nuestro Señor Jesucristo ${ }^{53}$. Ciertamente, es llamado hereje aquí el que niega a sabiendas un solo artículo de fe, incluso antes de que la Iglesia (lo) determine (como hereje). Cuando uno no sabe que lo que niega es algo determinado por la Iglesia, es posible que permanezca perfectamente en él la fe infusa; es más, ha de decirse que permanece ${ }^{54}$.

A la interpretación correcta de la Escritura se llega desde la Iglesia. El artículo de fe está en la Biblia; pero se le conoce porque lo señala la Iglesia. ¿Quiere esto decir que la Iglesia es mayor en autoridad que la Sagrada Escritura? Si se habla sin más y absolutamente, no puede hablarse de mayor autoridad. Ambas vienen de Dios. Ciertamente, una es más mediata o inmediata que la otra; pero esto hace poco al ser de fe tanto que la Iglesia no puede errar como que no puede hacerlo un evangelio. Esto es así por más que lo nieguen los herejes ${ }^{55}$. Cuando se compara la Iglesia con la Sagrada Escritura, no deben incluirse en aquélla a los Apóstoles. Entonces es lo mismo comparar la Iglesia con la Sagrada Escritura que con los Apóstoles mismos. Debe tomarse la Iglesia sin los Apóstoles, con la Iglesia que no puede redactar la Escritura. Los Apóstoles pueden redactar a solas la Escritura por disponer de la revelación inmediatamente. Esto no puede hacerlo la Iglesia al no recibir inmediatamente

tali dispositione fides infusa. Ergo illa sufficit ad introducendum fidem, quod est falsum". M 37v $(5,3)$.

52 "In fide autem non sic est quia non solum est unitas habitus unitate obiecti, sed etiam est unitas ex parte medii quo habitus fidei inclinat ad conclusiones fidei, scilicet quia revelantur Deo. Et sic qui negat auctoritatem ecclesiae negat modum procedendi in fide". M 38r $(\mathrm{V}, 3)$.

53 "Qui habet fidem infusam diutius durabit in fide quam alius. [...] Videmus quod haereticus circa unum articulum facilius labitur in errorem alterius. [...] Nunquam vidimus quod aliquis haereticus moveretur pro sua haeresi sicut christiani mortui sunt pro sua fide et pro domino nostro lesu Christo". M 38r (V,3).

54 "Haereticum vocamus qui negat articulum fidei, etiam ante determinationem ecclesiae, sicienter quia, si nesciat determinaum esse ab ecclesia, bene potest manere fides infusa, immo manet". M $37 \mathrm{v}(\mathrm{V}, 3)$.

55 "Ultima conclusio. Quod simpliciter et absolute non potest dici maior postquam utraque est a Deo, nam quod sit mediatior vel inmediatior parum facit postquam est tam de fide quod ecclesia non potest errare sicut evangelium, licet haeretici negent". R 67r (I,10). 
las revelaciones. Nada quita esto para determinar los artículos extrayéndolos de la Escritura. Así es como se habla aquí de la Iglesia con autoridad sobre la Sagrada Escritura ${ }^{56}$.

La autoridad de los Apóstoles es divina. La Sagrada Escritura es la aserción de los Apóstoles y, en consecuencia, es también aserción del mismo Dios. Por este motivo es la de la Sagrada Escritura la autoridad suma y puede decirse incluso que Dios no posee mayor autoridad que la Escritura. Los evangelistas no poseen la autoridad desde la Iglesia sino desde el mismo Dios. Tampoco creen los cristianos a los Apóstoles por mandarlo la Iglesia sino por mandarlo Dios. Es la Iglesia solo causa por la que uno ha de creer que lo que se lee en los evangelios lo dijo realmente el evangelista. Pero, una vez que el cristiano cree que tal es evangelista, no se cree ya a sus dichos por mandarlo la Iglesia sino ser inclinado desde el hábito de la fe a asentir a lo que dice como dicho por $\operatorname{Dios}^{57}$. La autoridad de la Sagrada Escritura es la de los Apóstoles. Hablaban éstos por la revelación inmediata de Dios. Ha de reconocerse con todo que [1a] autoridad de la Iglesia se funda también en la revelación de Dios; pero es algo que se realiza por medio de la Escritura Sagrada ${ }^{58}$. La autoridad de la Iglesia es divina y es la misma especie de herejía negar la de la Iglesia que existe ahora y la del concilio congregado legítimamente que negar una proposición de un evangelio. Es revelación divina lo que determina el concilio, aunque [ella] sea mediata en sí. Es igual que Dios revele la Escritura por los Apóstoles o que explique (aclare) por la Escritura al concilio un artículo. Pero ha de reconocerse que sería pecado más grave en la misma especie negar una proposición de un evangelio o de San Pablo ${ }^{59}$.

56 "Quando comparamus ecclesiam ad sacram scripturam non habemus in ecclesia includere apoSotolos, immo idem est comparare ecclesiam ad sacram scripturam et comparare ad apoostolos. Sed debet accipi ecclesia seclusis apostolis pro ecclesia quae non potest condere scripturam. Diximus quod soli apostoli per inmediatam revelationem possunt condere scripturam, sed ecclesia seclusis aposttolis quia non recipit inmediate revelationes, non potest condere scripturam, sed potest determinare articulas quatenus sequuntur ex sacra scriptura. Et de auctoritate huius ecclesiae loquimur". R 66v (I,10).

57 “Auctoritas apostolorum est auctoritas divina. Et scriptura sacra quae est assertio apostolorum, est assertio ipsius Dei, qua re illa est summa auctoritas, immo nec Deus est maioris auctoritatis quam ipsa scriptura. [...] Evangelistae non habent auctoritatem ab ecclesia sed ab ipso Deo, nec credimus illis quía ecclesia praecipit, sed quía Deus praecipit. [...] Ecclesia solum est causa quía ego credam haec esse dicta evangelistae. Sed postquam credo quod iste est evangelista, non credo dictis eius quía praecipit ecclesia sed ex habitu fidei inclinor ad assentiendum dictis eius tanquam dictis Dei”. R 67r (I,10).

58 "Utrum sit tanta auctoritas ecclesiae sicut sacrae scripturae. Auctoritas sacrae scripturae, ut diximus modo, est auctoritas apostolorum qui loquebantur ex revelatione Dei inmediata. Auctoritas ecclesiae est fundata etiam in revelatione Dei sed mediante scriptura". R 66v (I,10).

59 "Sed dubium est e converso utrum scriptura ve! apoostoli sint maioris auctoritatis quam ecclesia seclusis apostolis [...]. Sit $3^{\text {a }}$. propositio quod auctoritas utraque est divina [...]. $4^{\mathrm{a}}$. conclusio. 
La Iglesia no recibe revelación nueva alguna al redactar un artículo. No son las determinaciones de la Iglesia Sagrada Escritura. Ésta ha sido revelada inmediatamente por Dios. La de la Iglesia no viene inmediatamente de Dios sino por medio de la Escritura. La de los Apóstoles, y es el caso de la Biblia, se comporta como principio de la revelación de la Iglesia ${ }^{60}$. ¿Se ha de decir artículo de fe a toda proposición de la Escritura Sagrada? Al menos, ¿es requisito que el artículo de fe se encuentre en el canon de la Biblia? Ni basta ni se requiere estar en el canon de la Biblia (de suyo) ${ }^{61}$. Es Santo Tomás quien declara lo que se requiere al señalar que lo perteneciente a la fe se distingue en dos. Hay lo que pertenece a la fe primero absolutamente. Es lo que se espera poseer en la patria del cielo al consistir en ello la bienaventuranza o ser conducidos [los hombres] así a ella. Tales son los misterios de la Trinidad y los de la redención. Son éstos los propuestos a creer como de fe a los cristianos ${ }^{62}$. Si algo es o no es aceptado como artículo de fe, ello se debe solo a que así lo enseña la Iglesia ${ }^{63}$.

Eadem specialis haeresis esset negare auctoritatem ecclesiae quae nunc est et concilii legitime congregati et negare propositionem evangelii. Probatur quía etiam illud quod concilium determinaret esset revelatio divina licet mediata. ldem enim est quod Deus per apoostolos inmediate revelet scripturam et quod per scripturam revelet concilio explicationem alicuius articuli, Iicet gravius peccatum esset in eadem specie negare propositionem evangelii aut Pauli”. R 67r (I,10).

60 "Habemus ergo primum, quod ecclesiam instituere articulum non est recipere novam revelationem. Ex hoc sequitur $2^{\circ}$., quod determinationes ecclesiae non sunt sacra scriptura. Hoc connotat sacrae scripturae quod sit inmediate revelata a Deo. Revelatio tamen ecclesiae non est inmediate a Deo, sed per sacram scripturam. Et ideo revelatio apostolorum, puta sacra scriptura, se habet sicut principium respectu revelationis ecclesiae". R 66v $(\mathrm{I}, 10)$.

${ }^{61}$ Esta negación doble de Soto ha de ser entendida correctamente. No va contra lo que está defendiendo: que todo lo que ha de creer el cristiano obligatoriamente se halle de veras en la Biblia. Tampoco va contra el hecho de que todo nuevo artículo de fe se extraiga desde la Sagrada Escritura. Por esto, se ha puesto entre paréntesis de suyo, queriendo significar que hubo un tiempo en el que hubo fe y no hubo Sagrada Escritura. Esto quiere decir que no se ha de vincular esencialmente la fe a la Biblia. Se dio fe cuando no había Escritura. De ello se deduce que no es requisito el estar en el canon. Por otra parte, hay mucho en la Biblia que no es artículo de la fe.

62 "Alterum dubium est quid requiratur ut aliqua propositio sit articulus fidei et quid sufficiat. Et primo, utrum omnis propositio que est in sacra scriptura dicatur articulus fidei. Et si non omnis proposititio scripturae sacrae est articulus, utrum saltem requiratur ut sit in canone bibliae. Respondetur quod nec sufficit nec requiritur quod sit in canone bibliae. Sed s. Thomas in solutione ad 1 um. declarat quid requiratur. Dicit enirn quod illa quae pertinent ad fidem sunt in duplici differentia, nam aliqua sunt quae per se primo pertinent ad fidem, et illa sunt quae speramus in patria, in quibus consistit beatitudo ve! per quae perducirnur in beatitudinem, ut sunt mysteria trinitatis et mysteria redemptionis. Nam ista sunt quae proponuntur nobis ad credendum tanquam de fide". R 65r (I,6).

${ }^{63}$ Esto lo expone Santo Tomás al hablar de si están bien enumerados los artículos. Después de colocar las objeciones, pone el argumento de autoridad y dice: "Sed in contrarium est auctoritas Ecclesiae sic enumerantis". II-II, q. 1, a. 8. 


\section{La redacción del Sumo Pontífice}

Fue en el siglo IV cuando redactó la Iglesia el primer artículo nuevo de fe: la consustancialidad del Hijo respecto al Padre. ¿Quién hizo entonces la redacción? El concilio general. Ciertamente, cuando se habla de que la Iglesia puede redactar un artículo nuevo, quiere decirse que puede hacerlo el concilio general: la Iglesia. El concilio general son los obispos reunidos en armonía con el Papa. En este contexto se entiende correctamente la doctrina de Santo Tomás en el artículo décimo de la cuestión primera de la Secunda Secundae de que corresponde al Papa últimamente redactar el nuevo símbolo o el nuevo artículo de fe. Pero, ¿puede hacer esto únicamente el Sumo Pontífice con los obispos reunidos en concilio general o podría hacerlo, si fuera necesario, a solas; es decir, ¿sin tener que reunir el concilio ecuménico alguno? Radical en grado sumo fue al respecto Wiclef. Según el Waldense, fue el primero en decir que ni el Papa ni la Iglesia entera (el concilio general con el Papa) posee autoridad de redactar los artículos de fe ni de determinar algo como de fe ${ }^{64}$. En el siglo XVI, ningún católico pone en duda que la Iglesia (el concilio general con el Papa) es capaz de redactar un nuevo artículo. Hay todavía algunos católicos en el siglo XVI opuestos a que el Papa pueda redactar el artículo sin el concilio. La cuestión de si el Papa puede redactar el artículo de fe a solas se discute en el siglo XVI a causa de los retóricos. Éstos conceden que la Iglesia (el concilio general) es incapaz equivocarse; pero sostienen que puede errar el Papa a solas. Añaden que, aunque pudiera la Iglesia explicar como de fe algo desde la Sagrada Escritura, no puede hacerlo el Papa. Esta discusión de los retóricos la expone Alfonso de Castro (+1558), diciendo que el Papa puede errar por no estar exento de ser hereje, mientras esto no puede ocurrirle al concilio entero. Además, porque hay en los decretos papales no solo cosas que no son tenidas como de fe sino que entran en contradicción con lo dicho por otros papas, de donde se quiere deducir que alguno de ellos [de los sumos pontífices] erró ${ }^{65}$. A estas dudas expuestas por Castro se añade la de que, si el Papa puede hacer

64 "Primus omnium Ubicleft sermo. 45., ut refert Ubaldensis in 1. tom. lib. 2. cap. (sic) dicebat quod nec papa nec tola ecclesia habet auctoritatem condendi articulas fidei, nec determinandi aliquid tamquam de fide". R 66r (I,10).

65 "Aliud dubium est postquam ecclesia habet auctoritatem condendi articulum fidei, utrum etiam papa solus habeat eandem auctoritatem. Haec quaestio iam est inter rethores, nam concedentes quod ecclesia non potest errare dicunt quod papa potest errare, et licet ecclesia posset explicare tanquam de fide sacram scripturam, non tamen papa. Quidam modemus hoc late disputat in suo libro De haeresibus [Castro] verbo concilium. Ratio est quia papa potest esse haereticus et totum concilium non potest incurrere haeresim. ltem quia reperiuntur in decretis pontificum aliqua quae non tenentur tanquam de fide [...], immo aliquando est contradictio inter diversos pontífices [...]. Ergo alter illorum erravit”. R 67r (I,10). 
un artículo, ¿por qué no lo ha hecho todavía a solas? Se rechaza que pueda hacerlo porque, si lo hiciera, nunca se congregaría el concilio. Nunca se ha hecho la redacción sin el concilio ${ }^{66}$.

El Papa tiene la misma autoridad que el concilio a la hora de redactar un nuevo artículo de fe. Así lo sostiene Soto y señala además que Cayetano declara o esta verdad como firme, aunque se sostuviera al concilio como superior al Papa. Esto fue lo que quiso decir también Santo Tomás al colocar el texto en el que Cristo dijo a San Pedro: "Yo he rogado por ti para que no desfallezca tu fe, y tú, una vez convertido, confirma a tus hermanos" (Lc 22,32). Añade Soto que confirmar a los hermanos es hacerlos seguros en las dudas de la fe. El Aquinate citó asimismo el texto: "Apacienta mis ovejas". Es el principalísimo oficio del pastor instruir lo que entraña la fe $(\mathrm{Jn} 21,17)^{67}$. Además, la potestad del Papa viene inmediatamente de Dios, no de la Iglesia. Es admirable entonces que pueda decirse que (Cristo) le dio (a San Pedro) la suprema autoridad en la Iglesia sin darle la suprema autoridad de interpretar la Escritura. El Papa puede redactar perfectamente leyes en las que quedan ciertos los cristianos de ser [él] dirigido por el Espíritu Santo y no poder errar. Ésta razón se da en los artículos $^{68}$.

¿Qué responde Soto a las objeciones contra la redacción del Papa a solas? Puede ser el Papa ciertamente hereje. Lo será sin embargo solo como persona particular. Cuando se dice que nunca será hereje el Papa como tal, quiere decirse que, aunque puede tener alguna herejía, no se le permitirá que [él] la defina ante el pueblo como de fe de modo que éste la crea como de fe y se equivoque $^{69}$. Si existen divergencias entre los decretos de los papas, no se ha de decir que se está ante una determinación de fe. A veces, hablan los papas

${ }^{66}$ "Sed tamen habetur dubium. Si papa potest facere articulum quare nunquam fecit ipse solus. Videtur quod nunquam opus esset congregare concilium et tamen de facto nunquam fecit sine concilio". R 67v $(\mathrm{I}, 10)$.

67 "Dicimus secundo quod papa habet eandem auctoritatem condendi articulum sicut concilium, et hoc praetendit s. Thomas, ut etiam declarat dominus Caietanus, etiam si concilium esset supra papam. [...] Et illud quod citat s. Thomas: Ego rogabo pro te et tu aliquando conversus conjii71U1 fratres tuos. Et certe confirmare fratres est securos facere de dubiis fidei. Et illud Ioann. 21. Pasee oves meas. Et potissimum officium pastoris est instruere in fidem". R 67r-67v $(\mathrm{I}, 10)$.

68 "Item quia potestas papae est inmediate a Deo et non ab ecclesia, mirabile est quod dicas daret illi supremam potestatem in ecclesia et non daret auctoritatem interpretrandi scripturam. Et ultimo argumentatur quía papa potest perfecte condere leges in quibus certi sumus quod regitur a Spiritu Sancto nec potest errare. Ergo eadem est ratio de articulis fidei”. R 67r-67v $(\mathrm{I}, 10)$.

69 "Ad prirnum argumentum in contrarium quod papa potest esse haereticus, concedimus tanquam particularis persona sed non tanquam papa. Volo dicere quod potest habere aliquam haeresim, tamen non perrnittetur determinare illam tanquam de fide credendam populo". R 67v $(\mathrm{I}, 10)$. 
(solo) como doctores ${ }^{70}$. El Papa puede determinar a solas el artículo de fe, consultando la Sagrada Escritura y haciendo humanamente lo que debe. Si no obrara así, habría que admitir el error del Papa; pero añade Soto que esto mismo le ocurriría también al concilio y a una persona singular: en asuntos humanos. Por supuesto, el Papa no obra como debe si, en asuntos gravísimos, no consultara a varones probos. Para consultarlos conviene (a veces ${ }^{71}$ ) reunir el concilio. Si no obrara así, el pueblo se escandalizaría al ver que determina asuntos gravísimos. Soto añade que fue esto lo que pretendió decir Santo Tomás ${ }^{72}$.

El artículo de fe es la verdad que ordena la Iglesia creer a todos expresamente. Por supuesto, los artículos viejos no fueron redactados por la Iglesia. Ésta los enseñó. Hay entonces artículos que los ha tenido siempre la Iglesia en su continua explicación como tales. Son los viejos. Hay artículos que, en un momento dado de la Iglesia, fueron redactados y colocados en un nuevo símbolo. [Tales son los nuevos] ¿Qué se requiere para considerar y tener una verdad como artículo [nuevo] de fe? No basta que se tome o apruebe algo comúnmente por la Iglesia para ser tenido como de fe. Tampoco basta con que sea algo que haya sido puesto en duda y, tras discusión tenida en un concilio, haya quedado determinado parcialmente en orden a ser tenido como de fe. No basta para que algo sea artículo como de fe que el concilio lo haya determinado como tal. En el sexto concilio de Constantinopla se determinó la existencia de dos voluntades en Cristo como de fe. De todas formas, no se propuso como artículo [nuevo]. Quedan todos obligados a saber expresamente los artículos de fe. El campesino no peca sin embargo si ignora la existencia de dos voluntades en Cristo $^{73}$.

70 "Et ad secundum eodem modo respondetur, quía quando est dissensio ínter decreta pontificum, non est dicendum quod aliquid eorum sit determinatum tanquam de fide, quía pontífices aliquando loquuntur tanquam doctores". R 67v $(\mathrm{I}, 10)$.

${ }^{71}$ Aquí se añade a veces, porque si fuera el asunto clarísimo y todos lo admitieran, no habría razón para que el Papa definiera sin el concilio. De todas, formas, el Papa solo no es la Iglesia. De ahí que deba asesorarse por varones probos; pero, para hacerlo, no hace falta convocar un concilio general.

72 "Respondetur quod papa potest determinare articulum fidei consulendo sacram scripturam et faciendo quod est in se more humano. Aliter errasset sicut concilium ipsum et singularis persona in rebus humanis. Non facit quod in se est nisi consulat viros probos in rebus gravissimis. Et ad consulendos illos expedit facere concilium. Aliter populus scandalizaretur si videret quod papa per se res gravissirnas determinaret. Et hoc est quod praetendit s. Thomas, ut patet in ratione sed contra". R 67v $(I, 10)$.

73 “Tamen ultimum dubium est quid requiratur ad hoc quod aliquid habeatur pro articulo fidei. Utrum satis est quod determinetur ab ecclesia vel utrum sufficit quod ecclesia receperit. Respondetur per propositiones. Prima. Non sufficit quod aliquid suscipiatur et approbetur communiter ab ecclesia ut habeatur pro fide. [...] $2^{\text {a }}$. Non sufficit quod aliquid sit dubitatum et disputatum in concilio et de- 
Artículo es lo determinado como de fe y que todos han de creer al ser propuesto por como tal la Iglesia para que todos lo crean $^{74}$. Se determina y propone para que todos lo crean y queden obligados a saberlo. Así se creen los artículos del Apostólico ${ }^{75}$. ¿Basta entonces [también] con estar algo en Nicenoconstantinopolitano para ser artículo de fe? Aunque se halle algo contenido así no basta para ser artículo de fe. Ha de ser propuesto de la manera indicada ${ }^{76}$. Todo lo expresado en el Nicenoconstantinopolitano es de fe. Lo es entonces que el Espíritu Santo procede del Padre y del Hijo; pero [eso] no es artículo. No pecan los campesinos si lo ignoran ${ }^{77}$. Hay diferencia entre ser de fe y ser artículo. Es de fe lo revelado que hay que creer por estar propuesto, como [lo son] toda la Sagrada Escritura y las determinaciones de los concilios. Para ser artículo de fe es preciso además que haya sido propuesto a todos para que lo crean. Todo cristiano está obligado entonces a saberlo ${ }^{78}$.

No se ha de tener como de fe todo lo que ha llevado a cabo la Iglesia. Fija Soto la atención ahora en la canonización de los santos ${ }^{79}$. No es absolutamente de fe que el canonizado como santo lo sea de veras ${ }^{80}$. La fe (y también el ar-

terminatum ad unam partem ad hoc quod habeatur tanquam de fide. [...] $3^{\text {a }}$. Non sufficit adhuc ad hoc quod sit articulus fidei quod sit determinatum in concilio tanquam de fide. Nam in concilio Constant. determinatum est quod Christus habuit duas voluntates, et tamen hoc non est articulus. Probatur quia articulos fidei quilibet tenetur expresse scire. Et tamen non est peccatum quod rusticus ignoret quod Christus habuit duas voluntates". R 67v (I,10).

74 "Articulus fidei est propositio deterrninata tanquam de fide quam omnes tenentur credere, et proponitur ab ecclesia tanquam de fide ut ab omnibus credatur “. M 20r (I,10).

75 "Sed requiritur ad hoc quod aliquid sit articulus fidei quod sit determinatum et propositum omnibus ad credendum, itaque ornnes teneantur scire sicut sunt articuli qui ponuntur in symbolo apoostolorum". R 67v $(\mathrm{I}, 10)$.

76 "Articulus fidei est propositio determinata tanquam de fide quam omnes tenentur credere, et proponitur ab ecclesia tanquam de fide ut ab ornnibus credatur. Immo addo quod etiam si contineatur in symbolo nicaeno, non sufficit ut sit articulus fidei nisi sic proponatur". M 20r (I,10).

77 "Immo proprie loquendo non omnia quae sunt expressa in symbolo nicaeno sunt articuli fidei quanquam sint de fide, sicut est illud quod Spiritus Sanctus procedit a Patre et Filio, nam rustici hoc ignorantes non peccant”. R $67 \mathrm{v}(\mathrm{I}, 10)$.

78 "Itaque aliud est esse de fide, aliud est esse articulum fidei. Nam illud est de fide quod est revelatum pertinens ad religionem et quod, si proponeretur alicui ab ecclesia, tenetur credere, sicut esl tota sacra scriptura et determinationes conciliorum. Sed ad hoc quod sit articulus requiritur quod sit iam propositum ornnibus ad credendum ut ornnis teneatur scire". R 67v $(\mathrm{I}, 10)$.

${ }^{79} \mathrm{La}$ enseñanza de Soto en este punto ha sido expuesta ya en el amplio marco de los salmantinos, cfr. I. Jericó Bermejo, "Canonización e imposibilidad de error. La enseñanza manuscrita de la Escuela de Salamanca", Studium 33 (1993): 237-277.

80 "Non ornnia gesta ecclesiae necessarium est ut habeantur tanquam de fide, sicut canonizatio sanctorum. Non est simpliciter de fide quod sanctus qui canonizatur, sit sanctus “. R 67v (I,10). 
tículo) la determina la Iglesia desde la Sagrada Escritura. En la canonización se determina; pero se hace desde hechos. La canonización consiste en un hecho concreto. De todas formas, la canonización ha de tenerse como algo muy cierto; pero no es preciso tenerla como de fe. De verdad, sería un error grave si la Iglesia tuviera a alguien como santo sin serlo ${ }^{81}$ y le dirigiera las oraciones. Sería ciertamente una temeridad y un pecado grave contradecir aquí a la Iglesia. No es la canonización de fe por hacerse solo desde un hecho cierto ${ }^{82}$.

\section{Epílogo}

La problemática del artículo nuevo de fe sigue a la del artículo viejo. En ésta se habla de cómo se explica la fe a través del paso del tiempo hasta que alcanza la plenitud en Cristo, de la naturaleza del artículo como verdad especialmente difícil, de su carácter principal en la revelación y, sobre todo, de su expresión en el Apostólico. Quien sabe los artículos viejos y los cree, cree la revelación entera conducente a la justificación y a la salvación. Esto no quiere decir que el conocimiento expreso de los artículos todos sea medio imprescindible para entrar en la gloria. En la problemática del artículo nuevo se expone en cambio qué es y se dice que viene de la Sagrada Escritura, que es impuesto infaliblemente por la Iglesia a todos para que lo crean de modo expreso, correspondiendo su redacción al Papa, sea en un concilio general o sea a solas (sin el concilio). Redactó la Iglesia ya artículos nuevos muertos los Doce y puede hacerlo también ahora si hubiera necesidad.

A la redacción de un artículo nuevo se oponen los herejes del tiempo. Así es como se refiere Soto a los protestantes en bloque. La doctrina de éstos sobre la Eucaristía en concreto no es nueva. Se halla ya en la doctrina de Juan Wiclef, a quien tienen todos precisamente en siglo XVI como un hereje. Lo que enseñan los herejes del tiempo es ciertamente sobre la Eucaristía la misma doctrina de Wiclef. También aparecen en la explicación de Soto los nombres de Durando y Netter, así como habla también de ciertos retóricos. Para contrarrestar a los herejes y para aclarar de una vez por todas cuál es la doctrina de

81 "Gesta et acta ecclesiae non est necesse quod habeantur omnia tanquam de fide, sicut canonizare sanctas, quia hoc consistit in quodam facto. Sed nihilominus illud tenendum est tanquam certissimum licet non tanquam de fide. Et ratio quare tenendum est, certissima est quia esset gravis error si ecclesia haberet aliquem pro sancto qui non est". M 20r (I,10).

82 "Non est simpliciter de fide quod sanctus qui canonizatur, sit sanctus. Sed tamen credendum est tanquam certum quia esset maximus error quod ecclesia haberet pro sancto et funderet preces ad illum, qui non est vere sanctus. Et ita esset temerarium et grave peccatum contradicere in hoc ecclesiae. Sed lamen non est de fide quia illud consistit in quodam facto". R 67v $(\mathrm{I}, 10)$. 
Cristo, expusieron los padres conciliares en Trento la doctrina católica. Bastó la exposición tridentina para dejar patente quién estaba en la verdadera fe y quién se había apartado de ella. Católicos y herejes sabían a partir de entonces con claridad qué era y qué no era doctrina católica. Algo muy necesario en unos tiempos en los que casi todo se discutía. Ciertamente, puso Trento ante los ojos de todos una doctrina que a todos obligaba. Entre lo mucho que expuso, está lo relativo a la Eucaristía.

La fe que tenían los herejes del siglo XVI, ¿era acaso la misma que tenían los católicos? ¿Aceptaban todos los mismos artículos de fe? Así parecía ser, ya que unos y otros se atenían a lo expuesto expresamente en el Apostólico y en el Nicenoconstantinopolitano. Por supuesto, a nadie se considera hereje en el siglo XVI porque acoge enteramente estos dos símbolos de la fe católica. Pero se cae rápidamente en la cuenta de que, a pesar de acoger los mismos símbolos, no es la misma la fe que profesan los católicos y la que confiesan los herejes del tiempo. ¿Qué les separa? El artículo concreto de la Iglesia. No hay más que una Iglesia. Los herejes del tiempo no quieren ser de la Iglesia de los católicos: la obediente a Roma. Esto quiere decir ya sin más que no están los dos: católicos y protestantes, en la misma Iglesia. Si unos lo están, se ha de decir que no lo están los otros. ¿Quién está de verdad en la Iglesia de Cristo? Ciertamente, el interés de los teólogos se concentra en la realidad del artículo de la Iglesia y no es extraño que se traslade el interés tenido hasta entonces por la redacción de un nuevo artículo de fe a querer tener información sobre cuál es la Iglesia de Cristo. No es que se olvide la redacción del nuevo artículo de fe. Es que esto viene pedido en razón de los tiempos que corren. Por supuesto, todos los herejes del tiempo coinciden en un punto. Niegan que la verdadera Iglesia de Cristo sea la Católica. Nada extraña que, así las cosas, empezara a gestarse en la Escuela de Salamanca del siglo XVI el moderno tratado teológico de la Iglesia ${ }^{83}$.

En 1536 mantuvo Soto públicamente la posibilidad de que el futuro concilio llegara a redactar un nuevo artículo de fe, concretamente el de la presencia real de Cristo en la Eucaristía, en contra de los herejes del tiempo que negaban dicha verdad ${ }^{84}$. El manuscrito 940 de México, que se considera aquí de 1539, recoge una conclusión de Soto interesante de verdad: "En relación al Sacramento del Altar, aunque no se exprese como artículo en el símbolo que allí

${ }^{83}$ Cfr. I. Jericó Bermejo, "El moderno tratado De Ecclesia y sus inicios en la Escuela de Salamanca", Communio-Sevilla 28 (1995): 3-47; "Una Ecclesia Christi. El nacimiento del moderno tratado sobre la Iglesia y la Escuela de Salamanca (1559-1564)”, Revista Española de Teología 55 (1995): 331-389.

${ }^{84}$ D. de Soto, Ms. 13. Relectio de catalogo librorum sacrae scripturae. Biblioteca del Cabildo de la catedral de Palencia, fol. 271r. Cfr. nota 5. 
está el Cuerpo de Cristo, han de creerlo expresamente todos. Esto se prueba porque lo determinó la Iglesia contra Berengario, y lo propuso la Iglesia para que se crea al celebrar la fiesta del Corpus Christi; asimismo, porque estamos obligados a recibir la Eucaristía cada año" ${ }^{85}$. En la Suma Teológica dejó escrito Santo Tomás: "Después del tiempo de la revelación de la gracia, los mayores y los menores tienen obligación de creer explícitamente en los misterios de Cristo, principalmente en lo que en general se solemniza en la Iglesia y se propone públicamente, como es el caso de los artículos de la encarnación"\$6. En 1558 indicó Soto en particular a Bartolomé Carrranza: "Santo Tomás no dice sino todos los artículos, y principalmente los que solemniza la Iglesia", y le añadió: "Pero decir que han de saber explícitamente los otros misterios, necia cosa es obligarlos a tanto" ${ }^{\text {" }}$. Ante la imposición de la Inquisición Española, escribió Soto a Fernando de Valdés sobre este mismo punto, diciendo que esta solemnización de la Iglesia no llega a todas las verdades que hay sobre el bautismo, la pasión, la muerte o transfiguración de Cristo, "sino que [todos] son obligados a creer los artículos de la fe y principalmente los que solemniza la Iglesia" ${ }^{88}$.

[Sin quitar nada a lo publicado en 2003, se ha de decir aquí que en este punto aparentemente discordante entre Soto y Carranza, hay un error en lo que achaca fray Domingo a fray Bartolomé. Ello me ha dado ocasión para componer un artículo que, si no aparece con fecha de 2007, aparecerá con la de 2008. El mismo pone paz entre el uno y el otro, resultando que, una vez detectado el error, no hay lugar para pensar que hubiera contradicho Soto a Carranza.] (384*)

85 "Quantum ad sacramentum altaris, dato quod non sit articulus expressus in symbolo quod illic est corpus Christi, tenentur credere omnes expresse. Probatur, quia est determinatum ab ecclesia contra Berengarium et est propositum ecclesiae ut credatur, cum ecclesia celebrar festum de corpore Christi. 1tem, quía tenemur accipere eucharistiam semel in anno". M 15v (I,9).

86 "Post tempus autem gratiae revelatae tam majores quam minores tenentur habere fidem explicitam de mysteriis Christi, praecipue quantum ad ea quae communiter in Ecclesia solemnizantur, et publice proponuntur, sicut sunt articuli incarnationis". II-II, q. 2, a. 7c.

${ }^{87}$ Parece autógrafo de Domingo de Soto. El texto está publicado. Cfr. V. Beltrán de Heredia, Domingo de Soto. Estudio biográfico documentado (Salamanca, 1960): 678.

88 “Esta proposición también es falsa y rigurosa, porque Santo Tomás y los Santos no dicen sino que son obligados a creer los artículos de la fe y principalmente los que solemniza la Iglesia, como los misterios que hubo en el bautismo de Cristo y en la Pasiín y Resurrección suyas y en la Transfiguración, que no es obligatorio al pueblo a saberlo". Calificación del catecismo de Carranza. Cfr. V. Beltrán de Heredia, Domingo de Soto. Estudio biográfico documentado (Salamanca, 1960): 702 .

(384*) El artículo se titula: “¿Una discrepancia entre Domingo de Soto y Bartolomé Carranza? A propósito de una posible omisión textual”. 
Por supuesto, se redacta un nuevo artículo de fe cuando se coloca una verdad a todos los cristianos infaliblemente como de fe y con obligación de que todos la crean expresamente; es decir, cuando se les impone la obligación de que la sepan primero para poder creerla expresamente. ¿Quiere esto decir que, antes de la redacción de un artículo, no tenían los cristianos toda obligación de saber el nuevo artículo? Cuando Soto hizo su afirmación en 1536 sabía que la verdad de la presencia real de Cristo en la Eucaristía debían saberla todos. Lo sostuvo él en 1539 al decir que todos han de saberla por haber sido determinada dicha verdad contra Berengario, haberla propuesto la Iglesia al imponer la celebración de la fiesta del Corpus Christi y al obligar a todos a comulgar por Pascua. No reprocha entonces Soto a Carranza que diga por todo lo alto que todo cristiano está obligado a saber la verdad de la presencia real de Cristo en la Eucaristía. Le advierte de que se ha extralimitado al exigir creer también otras verdades que, de hecho, solemniza la Iglesia; es decir, celebra con solemnidad. Parece aquí que ese solemnizar tomado de Santo Tomás está haciendo referencia a los artículos llamados aquí nuevos. Si fuera ésta la verdadera comprensión, y creo que así es en la expresión de Soto, se estaría reconociendo abiertamente que el concilio de Trento había redactado ya como nuevo artículo de fe el de la presencia real de Cristo (334**) en la Eucaristía ${ }^{89}$.

¿Cambia las cosas la redacción por parte de la Iglesia de un nuevo artículo de fe si, según Soto, era obligatorio para todos antes saber que Cristo estaba realmente en el Sacramento del Altar? En 1536 y en 1539, antes de Trento, sostuvo esto como teólogo. La suya era una deducción a partir de unos determinados hechos. En 1558 puede decirse que sus palabras tienen mayor apoyo. La suya no sería ya la de un teólogo o la de muchos teólogos sino la de la Iglesia misma. Por cierto, desde mitad del siglo XVI, se desentienden los salmantinos del tratamiento de la problemática del artículo de fe y pasan todos a una a tratar sobre la Iglesia. Esto se explica fácilmente si se acepta que ha determinado ya la Iglesia un nuevo artículo. Así las cosas, no hay motivo para seguir planteando repetidamente la pregunta de si puede la Iglesia hacer un nuevo artículo de fe en el momento presente. Si lo ha hecho, puede hacerlo. Pero hay al parecer más y es que no todos los herejes del tiempo negaban entonces la verdad de la presencia real de Cristo en la Eucaristía.

(334**) Cf. I. Jericó Bermejo, "La presencia real de Cristo en la Eucaristía. ¿Se redactó esta verdad en Trento como artículo nuevo de fe?”, Revista Agustiniana 43 (2006): 285-310.

${ }^{89}$ Me permito adelantar que Carranza reaccionó contra Soto y le echó en cara que cómo podía negar que no hubiera necesidad de creer la verdad de la presencia real. Creo sinceramente que no entendió o no quiso entender Carranza lo que dijo Soto. En modo alguno se oponía a que todos tuvieran que saber esta verdad, sino a que hubiera que saber otras, las cuales era preciso creerlas; pero no era preciso creerlas expresamente. 
Concretamente, defendía Martín Lutero contra otros herejes que Cristo estaba allí realmente y no en figura o signo nada más. Lutero y los demás herejes del tiempo coincidían en un punto. No aceptaban que la Iglesia de Cristo fuera la católica. Todo el andamiaje de la problemática del artículo de fe basado en la autoridad de la Iglesia y de la Sagrada Escritura quedaba inservible si no se mostraba con claridad lo que se escondía y se significa en el artículo de la santa Iglesia católica (tal como lo formula el Apostólico) o de la Iglesia una, santa, católica y apostólica (tal como lo expresa el Nicenoconstantinopolitano).

\section{Bibliografía general}

\section{Manuscritos}

Peña, J. DE LA, Coimbra. Biblioteca General de la Universidad. T 19.

— Roma. Biblioteca Apostólica Vaticana. Ott. lat. 1046.

Soto, D. DE, México. Biblioteca Nacional. Ms. 940.

— Roma. Biblioteca Apostólica Vaticana. Ott. lat. 782.

Vitoria, F. DE, Salamanca. Biblioteca de la Universidad. Ms. 43, fol. 17v.

- Roma. Biblioteca Apostólica Vaticana. Ott. lat. 1015a, fol. 8r.

\section{Libros}

Bainton, R. H. Lutero. Torino, 1960.

Becker, K. J. Die Rechtfertigunslehre nach Domingo de Soto. Roma, 1964.

Belda Plans, J. La Escuela de Salamanca. Madrid, 2000.

Beltrán de Heredia, V. Domingo de Soto. Estudio biográfico documentado. Salamanca 1960; - Francisco de Vitoria. Barcelona-Madrid, 1939.

Denzinger, H. y Schonmetzer, A. Enchiridion symbolorum, definitionum et declaratioinum de rebus fidei et morum. Barcelona, 1976.

Fray Pedro de Aragón y Fray Luis de León, Autoridad de la Iglesia y autoridad de la Escritura. Textos salmantinos. [Edición, traducción e introducción de Ignacio Jericó Bermejo]. Madrid, 2007.

Goñi Gaztambide, J. Historia de los obispos de Pamplona. III. S. XVI. Pamplona, 1985.

Mori, E. G. Il motivo dellafede. Da Geaetano a Suarez. Roma, 1953. 
Soto, D. de. Relecciones y opúsculos. III. Edición, traducción y notas de José Carlos Martín de la Hoz e Ignacio García Pinilla. Salamanca, 2005.

García Villoslada, R. Raíces históricas del luteranismo. Madrid, 1976.

Jericó Bermejo, I. De articulus fidei hacia dogma fidei. El camino entre la doctrina y verdad de fe católicas en la Escuela de Salamanca (15261584). Vitoria, 1981.

- Fray Luis de León. La teología sobre el artículo y el dogma de fe (1568). Madrid, 1997

- La Escuela de Salamanca del siglo XVI. Una pequeña introducción. Madrid, 2005.

Maritain, J. Tres reformadores: Lutero, Descartes, Rousseau. Buenos Aires, 1945.

Martínez Fernández, L. Sacra doctrina y progreso dogmático en los Reportata inéditos de Juan de Guevara. Dentro de la Escuela de Salamanca. Vitoria, 1967.

Pesch, O. H. Tomás de Aquino. Límite y grandeza de una teología medieval. Barcelona, 1992.

Santo Tomás de Aquino, Summa Theologia. Tomus III. Secunda Secundae. Taurini, 1928.

\section{Artículos}

Barrientos García, J. "La Escuela de Salamanca: desarrollo y caracteres". La Ciudad de Dios 208 (1995): 1041-1079.

Becker, K. J. "La tradición manuscrita de las prelecciones de Domingo de Soto". Archivo Teológico Granadino, 29 (1966): 125-180.

— "Soto, Domingo de". Theologische Realencyclopedie 31, Berlín-Nueva York, 2000, 479-480.

Belda Plans, J. "Hacia una noción crítica de la Escuela de Salamanca". Scripta Theologica 31 (1999): 367-411.

Beltrán de Heredia, V. "Soto, Dominique de". Dictionnaire de Théologie Catholique 14/2 (París 1941): 2423-2428.

Domínguez, F. “Theologiegeschichtlich”. Lexikon für Theologie und Kirche 8, Freiburg im Breisgau, 1999, 1476.

— "Soto, Domingo de". Lexikon für Theologie und Kirche, 9, Freiburg im Breisgau, 2000, 745-746.

Ehrle, F. (March, J. M.). "Los manuscritos vaticanos de los teólogos salmantinos del siglo XVI. De Vitoria a Báñez". Estudios Eclesiásticos 8 (1929): 141-172; 289-331; 433-455:9 (1930): 145-187. 
Fraile, G. "Soto, Domingo de". Diccionario de Historia Eclesiástica de España 4, Madrid, 1975, 2507b-2508a.

García Miralles, M. "Soto, Domingo de". Gran Enciclopedia Rialp 21, Madrid, 1975, 637-638.

Jericó Bermejo, I. "Canonización e imposibilidad de error. La enseñanza manuscrita de la Escuela de Salamanca". Studium 33 (1993): 237-277.

- "Condere articulum fidei et condere Sacram Scripturam. El poder eclesial según Domingo de Soto". Archivo Teológico Granadino 56 (1993): 63-130.

— "Doctrina fidei catholica". Scriptorium Victoriense 31 (1984): 242-245.

- "Domingo de Soto. A propósito de un texto romano sobre la herejía". Toledana 13 (2005): 406-431.

- Domingo de Soto y los nuevos artículos de fe (s. XVI). Homenaje al Padre Karl Josef Becker S. J. Valencia, 2003, 49-72.

— "El moderno tratado De Ecclesia y sus inicios en la Escuela de Salamanca". Communio-Sevilla 28 (1995): 3-47.

- "La presencia real de Cristo en la Eucaristía. ¿Se redactó esta verdad en Trento como artículo nuevo de fe?". Revista Agustiniana 43 (2006): 285-310.

- "Las re lecciones de Domingo de Soto sobre la Sagrada Escritura (15361538): Introducción”. Communio-Sevilla 40 (2007): 57-100.

- "Una Ecclesia Christi. El nacimiento del moderno tratado sobre la Iglesia y la Escuela de Salamanca (1559-1564)". Revista Española de Teología 55 (1995): 331-389.

Martín de la Hoz, J. C. y Belda Plans, L. "La Relectio de catálogo librorum Sacrae Scriturae de Domingo de Soto". Burgense 24 (1983): 213-314.

Martín de la Hoz, J. C. "Domingo de Soto: Relectio de Sensibus Sacrae Scripturae". Archivo Dominicano 11 (1990): 275-318.

— La Relectio de Sacro "Canone et eius sensibus de Domingo de Soto". Scripta Theologica 14 (1982): 759-805.

Pozo, C. "Soto, Domingo de". Lexikon für Theologie und Kirche 9, Freiburg im Breisgau, 1964, 897-898.

— "Domingo de Soto. Relección De haeresi". Archivo Teológico 16 (1963): 223-261.

- "Salmantizenser". Lexikon für Theologie und Kirche 9, Freiburg im Breisgau, 1964, 268-269. 


\section{Bibliografía sobre Domingo de Soto}

\section{Manuscritos}

Los datos aquí expuestos han sido tomados del estudio de Karl Josef Becker. Allí se pueden encontrar los datos sobre el contenido y sobre la fecha ${ }^{90}$. Cf. K. J. Becker, "Tradición manuscrita de las prelecciones de Soto". Archivo Teológico Granadino 29 (1966): 125-166.

a) En España:

Granada. Biblioteca Universitaria.

Códice G. Caja B-5 ${ }^{91}$.

Madrid. Archivo de la Universidad Central. Facultad de Ciencias Políticas y Económicas.

Ms. $120-Z-15$.

Ms. $120-Z-26$.

Madrid. Archivo Histórico Nacional.

Sección Universidades 1198.

Sección Universidades 1202.

Madrid. Biblioteca Nacional. Sala de Manuscritos.

Ms. 6809.

Ms. 6076.

Madrid. Monasterio del Escorial.

MS. P-III-28.

${ }^{90}$ Aunque todos los manuscritos aquí expuestos figuran como de Soto, hay que tener muy en cuenta lo anotado por Becker:

"De esta visión de conjunto sobre los manuscritos de Domingo de Soto, hoy conocidos, se deduce que una serie de ellos quedan excluidos de[sde] una comparación ulterior: [...] Está doblemente citado: Archivio OP A 65: es idéntico con XIV 245. No son de Soto: Roma, Ott. lat. 782, fol. 229-271, in I-II qq. 89, qq. 109-114 anónimo. Ott. lat. 1056, in III q 1-59: Vitoria. Madrid, Bibl. Nac. Ms. 6809, De reprobatione: Pedro de Soto. Londdon, Lambeth-Palas-Bibliothek 424, annotationes in Joannem: Ludovico de Soto". K. J. Becker, "Tradición manuscrita de las prelecciones de Soto", Archivo Teológico Granadino 29 (1966): 166.

91 "GRANADA. El manuscrito 1-47-13. Hoy caja B-5, contiene en los fol. 419-429 la relección Dedominio. [En verano 1961 no me fue accesible el manuscrito.]”. K. J. Becker, "Tradición manuscrita de las prelecciones de Soto", Archivo Teológico Granadino 29 (1966): 154. 148, nota 4. Sobre la descripción del códice de Granada, cf. D. de Soto, Relecciones y opúsculos. I. Introducción, edición y traducción de Jaime Bruja u Prats (Salamanca, 1995): 17 -19. 
Palencia. Biblioteca Capitular.

MS. A-3-13.

Salamanca. Biblioteca de la Universidad Civil.

M 43 (antes 4-6-15) 92.

M 58 (antes 2.-313).

Salamanca. Convento de San Esteban.

Ms sin catalogar: In gloriam do mini nos tri les u Christi filii Dei unici, scholia reverendi Patrisfratris Dominici de Soto Magistri sacrae thelogiae supre primam secundae partis summae s. Thomae edita anno Domini MDLIII in achademia salmantina sum ibidem referet chathedram Primae (fol. 1r).

Sevilla. Biblioteca de la Universidad.

Ms. 333-166.

Valencia. Biblioteca del Corpus Christi o del Patriarca.

M 19.

M 24.

M 1757.

b) Fuera de España:

Évora (Portugal). Biblioteca Pública.

CXXIII/1-17.

Lisboa (Portugal). Biblioteca Nacional.

Fundo Geral2990.

Londres (Reino Unido). Lambeth-Palace-Library.

Ms. 424.

México. Biblioteca Nacional.

MS. 940.

Múnich (Alemania). ST AA Tsbibliothek. Handschriftenabteilung.

CLM 28-110.

Roma (Ciudad del Vaticano). Biblioteca Apostólica.

Ott. lat. 714.

Ott. lat. 781.

Ott. lat. 782.

Ott. lat. 1010.

Ott. lat. 1021.

Ott. lat. 1022.

${ }^{92}$ El 4-3-18: IN 1-II, se ha perdido. Ya no existía en 1931. Cf. Becker, "Tradición manuscrita de las prelecciones de Soto": 154. 
Ott. lat. 1042, 1-II.

Ott. lat. 1056.

Roma. (Italia) Santa Sabina. Archivo General de la Orden de Predicadores.

XIV-245.

\section{Impresos}

Aquí no se colocan como obras impresas las que se imprimen desde los manuscritos, sino las que quiso Domingo de Soto que fueran dadas a la imprenta $^{93}$. Aquí se expone sucintamente lo que puede encontrarse con más detalle en: BELTRÁN DE HEREDIA, V., Domingo de Soto. Estudio biográfico documentado, (Salamanca 1960) 526-545.

a) De filosofia:

In Dialecticam Aristotelis: Isagoge Porphyrii; Aristotelis Categoriae; De Demonstratione. Burgos, Juan de Junta 1543.

Summulae. Salamanca, Juan de Junta 1529.

Super octo libros Physicorum commentarii. Salamanca, Juan de Junta 145 ?

Super octo libros Physicorum Quaestiones. Salamanca, Juan de Junta 1945?

b) De teología:

Apologia qua rev. Patri Ambrosio Catharino, episcopo Nonoriensi, de certitudine gratiae respondet. Venecia, Nicolás de Bascharinis 1547.

Annotationes in Commentarium Joannis Fei super Evangelium Joannis. Salamanca, A. De Portonaris 1554.

Comentarium in Quartum Sententiarum. I. Salamanca, Juan de Canova 1557.

Commentarium in Quartum Sententiarum. II. Salamanca, A. De Portonaris 1560.

De caendo juramentorum abusu. Salamanca. A. De Portonaris 1552.

De cómo se ha de evitar el uso de los juramentos. Salamanca, A. De Protonaris 1551

De extremo judicio. Concio habita ad patres Tridentinos dominica prima Adventus anno 1545, No consta la ciudad ni quien la editó; pero consta el año de edición: 1545 .

${ }^{93}$ A esto se debe que no se cite aquí la obra editada en el siglo XVIVIII: Tratado del amor de Dios. Sobre este libro y su manuscrito, cf. V. Beltrán de Heredia, Domingo de Soto. Estudio biográfico documentado (Salamanca, 1960), 535-545. 
De justitia et jure, libri decem. Salamanca, Andrés de Portonaris 1553 (1554). De natura et gratia. Venetiis, apud Juntas 1547.

De ratione tegendi et detegendi secretum relectio. Salamanca, Pedro de Castro 1541.

In Epistolam divi Pauli ad Romanos Commentarii. Ambers, Juan Steelsio 1550.

Suma de la doctrina cristiana. Salamanca, A. De Portonaris 1552.

\section{Texto latino de las Relactiones y prae-lectio}

\section{Relectiones}

a) De sacro canone et eius sensibus (1536)

[R.a.1] [fol. 266r] ${ }^{94}$ Relectio reverendissimi P. fr. Dominici de Soto magistri circa Primum Sententiarum de sacro canone et eius sensibus habita Salmanticae. Anno a virgineo partu, 1536. Vidi in dextera sedentis super thronum librum scriptum intus et foris, Apocalip. $5^{\circ} .1^{\mathrm{a}}$ conclusio. Canon sacrae scripturae a Deo est inmediate revelatus, veteris quidem testamenti per prophetas, novi vero per apostolos aut per eos qui ab illis probati sunt. $2^{\mathrm{a}}$ conclusio. Ecclesia catholica praeter ${ }^{95}$ apostolos sacram scripturam non condere, sed per articulos fidei exponere potest atque dubia inde emergentia diffinire. $3^{\mathrm{a}}$ conclusio. Auctoritas sacrae scripturae inmediatior est, atque quodam modo prior auctoriate ecclesiae, non tamen maior sed sunt ambae pares quamvis auctoritate ecclesiae canon sacrae scripturae sit receptus.

[R.a.2] Disputationem hanc statuimus sacrarum scripturarum studium adeuntibus velut introductionem quamdam ob oculos ${ }^{96}$ ponere quae circa prologum Magistri Sententiarum collocatur ubi solent disputare doctoribus, fueritne hominibus necessarium scientiam aliquam supernaturalem divinitus revelari cuius nimirum est sacra scriptura. In cuius prothema locum illum delegimus qui est Apoca. $5^{\circ}$. ubi inquit lohannes: Vidi in dextera sedentis

\footnotetext{
${ }^{94}$ Palencia. Biblioteca del Cabildo de la Catedral. Ms. 13.

${ }^{95}$ Ms. propter.

${ }^{96}$ Ms. oculis.
} 
super thronum librum scriptum intus et foris, cui simile est illud Ezechielis $2^{\circ}$. Ecce manus missa ad me, in qua erat involutus liber, et expandit illum coram me, qui erat scriptus intus et foris. Ubi Gregorius homilia $9^{a}$. super Ezechielem: Liber (inquit) sacri eloquii intus scriptus erat per alegoriam, foris per historiam, quibus verbis genuinus insinuatur sensus sacrae scripturae: historicus scilicet seu literalis qui foris in superficie apparet, et spiritualis qui subtus latet, de quibus nostra erit disputatio.

[R.a.3] Verum enimvero ut rem paulo altius auspiceret, tria statueram et hic tractare. [fol. 266v] Primum, quis sit liber canonicus et quanta eius auctoritas. 2 um., quot et qui sint eiusmodi libri. Et 3 um, quotuplex sit horum librorum sensus. Sed tamen qui amphora cepit institui, currente rota urceus exiit. Quare certus me in presenti omnia absolvere non posse, ob idque dicam quod per temporis angustiam licuerit et in alia relectione quae me in brevi facturum polliceor Deo dante residuum absolvam.

[R.a.4] [Prima quaestio] ${ }^{97}$. In primo ergo puncto statuendum nobis est quisnam liber sit canonicus censendus; hoc est, quid requiritur ut sit canonicus. Et videtur disputatio nostra nomine ipso proficiscatur. Canon nomen graecum est quod latine redditum idem pollet quod regula, unde liber canonicus idem est quod regularis. Est enim membrum librorum ab ecclesia praescriptum qui divina pollet $^{98}$ auctoritate cui numero nec addi quicquam potest nec subtrahi, ideoque catalogus ille librorum merito nuncupatur regula, et quicumque liber illic ascriptus dicitur regularis vel sub aliis nominibus catalogus ille dicitur canon, et liber appellatur canonicus. Quod fit ut apud theologos ${ }^{99}$ non valeat idem canon sicut apud canonistas, nam ipsi sententias sanctorum patrum et decreta vocant canones. Qua significatione nos etiam utimur, sed in praesentia idem pollet liber canonicus ac si dicatis liber divinus, liber qui habet auctoritatem divinam. Unde librum canonicum solent sic discribere: Liber canonicus est cui nefas ${ }^{100}$ atque haeresis est contradicere, immo cuius nihil quod illic assertum esset licet vel dubitare. Quam ut reor diffinitionem colligunt ex Augustino in epistola ad Hieronynum quaestione 19. Et habetur dist. 9. Capite ego solis, ubi inquit ego solis eis scripturarum libris ${ }^{101}$ qui iam canonici appellantur didici hunc timorem

${ }^{97}$ Lo comprendido entre corchetes se halla al margen. Así ocurre siempre en el texto latino. En el texto castellano ocurre que se colocan a veces los corchetes para hacer mejor sentido a una frase. Así, en el texto castellano, hay que comprobar si esos corchetes que aparecen están o no están en el texto latino. Si están, el texto corresponde a Soto. Si no lo están, corresponde el texto solo al traductor.

\footnotetext{
${ }^{98}$ Ms. polent.

${ }^{99}$ Ms. theologus.

${ }^{100}$ Ms. nephas.

${ }^{101}$ Ms. libros.
} 
honoremque deferre ut nullum eorum auctorem scribendo aliquid errasse firmissime credam. Sed esto ita sit quod ille sit liber pro canonico habendus, de cuius auctoritate dubitare non licet.

[R.a.5] Est tamen dubium nostrum circa causam huius auctoritatis libri canonici. Utrum videlicet ut liber quisque sit canonicus requiratur quod sit revelatus a Deo. Nam id omnes pro comperto habent, et tamen videtur mihi dignum expositione. Arguitur enim sic pro parte negativa. Primo, multa sunt in sacro canone quae fuerunt scriptoribus nota sine aliqua speciale vel spirituali revelatione. Hoc patet in historiis utriusque testamenti. Scripsit enim Moyses exitum Israel de Aegypto, peregrinationem deserti, quae propriis oculis vidit. Et Iosue ut fertur scripsit historiam suam. Item historiam ludicum, Regum, Paraliponenon, haec omnia sine revelatione fuerunt cognita. Item in novo testamento Matthaeus scripsit vocationem suam et praedicationem Christi. Et pariter Iohannes, quae omnia naturaliter conspexerunt. Et Lucas scripsit Acta apostolorum. Et Marcus scripsit evangelium referente illi Petro, et Lucas referente Paulo, et ceteris apostolis, ut post Papiam antiquissimum auctorem scripsit Hieronymus in de viris illustribus ${ }^{102}$ et omnes ita dicunt. Ergo illa non scripserunt ex revelatione. Unde Augustinus in principio statim primi libri de consensu evangeliorum non videtur fundare auctoritatem evangelistarum in revelatione aliqua sed quia fideliter scripserunt quae viderant vel ab aliis audierunt, et adversus Faustum Manichaeum evertentem auctoritatem [fol. 267r] evangelistarum eodem utitur argumento.

[R.a.6] Accedit ad hoc auctoritas ipsorum apostolorum. Nam Actuum $4^{\circ}$. Petrus et Ioannes. Non possumus (inquit) quae vidimus et audivimus non loqui. Et Ioannes in prima sua canonica capite $1^{\circ}$. Quae vidimus et audivimus oculis nostris et manus nostrae contrectaverunt annuntiavimus vobis. Et Lucas in prologo sui evangelii dicit se narrationem rerum ordinare sicut tradiderunt (inquit) nobis qui ab initio ipsi viderunt et ministri fuerunt sermonis. Ecce quomodo sancti apostoli non referunt testimonium suum in aliam supernaturalem revelationem, sed quod testes fuerunt oculati. Quod si quis dixerit Christum ipsum revelasse illis in suam praedicationem fuisse revelationem, fatemur hoc posse dici de aliquibus supernaturalibus veritatibus. Nam fuit Ioanni in baptismate Christi revelatum quod esset verus filius Dei ut ipse testatur Ioannis $1^{\circ}$. Et ipse Christus revelavit discipulis resurrectionem apparens eis, sed tamen aliorum quae naturaliter cognoscerat quid opus est revelare? Et confirmatur haec tandem. Si Iosephus vel quilibet alius historicus qui esset praesens scripsisset illam historiam, non esset scriptura canonica nec videtur maiorem revelationem habuisse Matthaeus de vocatione sua, quare

\footnotetext{
${ }^{102}$ Ms. illustris.
} 
ergo illa dicitur revelata et canonica magis quam si modo quis vellet facere historiam de bello punico aut gallico.

[R.a.7] Pro parte affirmativa est Paulus ad Hebraeos. Imprimis, multifaries multisque modis olim Deus loquens patribus in prophetis, movissime autem in diebus istis locutus est nobis in filio ubi docet utrumque testamentum fuisse revelatum per os sanctorum qui a seculo sunt prophetarum eius. Et 2ae. Petri $1^{\circ}$. Non enim voluntate humana allata est aliquando prophetia sed Spiritu Sancto inspirante locuti sunt sancti Dei homines. Accedit eadem ratio, nam si scriptura non esset auctoritate Dei conscripta, posset falsum continere, quia omnis homo mendax Ps. 115. Sed scripturam sacram (ut diximus) appellamus cui non est fas contradicere. Ergo requiritur quod sit a Deo revelata.

[R.a.8] Dubium hoc submovimus ut exponamus qualis revelatio requiratur ut scriptura sit canonica. Ad quod rendemus tali distinctione. Revelatio dupliciter potest capi. Uno modo proprie pro infussione scientiae quae fit supernaturaliter. Hoc enim sonat proprium nomen revelationis sive fiat per infussionem habitus ut in baptismate infunditur habitus fidei, sive species ut prophetis induebantur species repraesentantes futura, et quae distabant ab humana cognitione, sive utrumque infundatur sicut primoparenti est verisimile quod infusa fuerunt et species rerum et habitus scientiarum, sive sola notitia actualis ut forsan Paulo in raptu. Omnes enim istae dicuntur proprie revelationes, immo predicatio ipsa Christi et Apostolorum de mysteriis fidei est vera revelata.

[R. a.9] Et de hac constituimus primam propositionem. [Prima propositio] est. Non requiritur ut scriptura sit canonica ut sic hoc modo revelata. Hanc puto abunde ${ }^{103}$ probatam inter arguendum. Alio modo accipitur revelatio, quae significantius dicitur inspiratio pio motu Spiritus Sancti quo scilicet movet aliquem scriptorem ad scribendum et servat ipsum ne possit errare.

[R.a.10] Et est $2^{\mathrm{a}}$ conclusio. [ $2^{\mathrm{a}}$ propositio,] quod haec revelatio requiritur ad auctoritatem libri canonici v.g. Moyses et Matthaeus multa scripserunt quae naturaliter cognoverunt, attamen non fuerunt moti ad scribendum [fol. 267v] ratione humana sicut Iosephus v. g. et Livius, sed moti spirituali inspiratione Spiritus Sancti, et ideo tenebantur quantum ad voluntatem ne mentirentur, aliter scribendo quam noverant, et quantum ad intellectum ne laberentur memoria. Nam saepe usu venit quod etiam occulati testes aliter referant res quae sunt gestae, ut constat de illis qui fuerunt in teathro. Alii aliter referunt quod omnes viderunt et per haec non tam proprie dicatur revelatio. Patet, quia non est semper infusio scientiae, nec est solum circa intellectum sed circa voluntatem. Quapropter licet posset quoque dici revelatio, significantius

${ }^{103}$ Ms. habunde. 
tamen dicitur inspiratio, et ita Petrus inquit non voluntate humana sed spiritu sancto inspirante locuti sunt sancti Dei omnes; id est, spiritu sancto movente voluntates.

[R.a.11] Subsequitur $2 u m$. dubium. Postquam non requiritur illa revelatio primo modo, utrum saltem sufficiat quaecumque revelatio ut liber sit canonicus. Et videtur quod sic. Nam videtur quod idem pollent liber revelatus et liber canonicus. Et respondetur per duas propositiones. Prima, revelatio primo modo quae est infusio scientiae supernaturaliter sicut non requiritur, ita non sufficit ut scriptura sit canonica. Probatur. Si Deus postquam revelavit Isaiae mysteria cuncta ${ }^{104}$ quae scripsit permisisset eum humano modo scribere, itaque licet fideliter cuncta narrasset, tamen humana virtute veritatis sicut scripsisset Cato et sicut scripsisset Hieronymus, non esset scriptura canonica, quia licet esset vera, tamen non haberet certitudinem divinam sed fallibilem. Ex quo sequitur quod revelatio isto modo est impertinens ad auctoritatem libri canonici licet saepe concurrat ut in prophetis et in apostolis.

[R.a.12] $2^{\mathrm{a}}$ propositio. Revelatio $2^{\circ}$. modo sicut requiritur, ita etiam sufficit ad auctoritatem libri canonici, nam quidquid homo scripsisset Deo movente et inspirante licet illud cognovisset naturaliter, esset scriptura canonica dummodo recitaretur ab ecclesia tanquam pertinens ad fidem. Ubi notandum quod licet ipso modo esset revelata, si Ecclesia non acceptasset, non esset scriptura canonica, quia ut infra videbimus, ad ipsam spectat determinare quae scriptura sit canonica, immo forse requireretur quod esset alicuius veritatis pertinentis ad fidem vel ad mores fidelium. Nam licet constaret modo quod Deus revelavit pastori in campo futurum aliquod exilium orbis vel bonam fortunam alicuius, non continuo esset scriptura canonica.

[R.a.13] Est 3um. dubium, quod continuo oritur ex dictis, utrum quicumque concursus Spiritus Sancti dummodo sit spiritualis motio, sufficiat ad auctoritatem libri canonici. Et particulariter movetur propter concilia generalia et propter decreta pontificum, adminus secundum s. Thomam et illos qui tenent papam non posse errare in his quae pertinent ad fidem. Sed loquamur de concilio legitime congregato ut omnes catholici conveniamus. Videtur enim quod acta concilii iuxta illa quae dicta sunt, sint etiam sacra scriptura, nam concurrit specialiter Spiritus Sanctus cum ecclesia ut non possit errare iuxta illud Lucae 22. Ego rogavi pro te ut non deficiat fides tua. Et Matth. 18. Ubi fuerint duo vel tres congregati in nomine meo, ibi sum in medio eorum. Immo est determinatio ecclesiae quod concilium non potest errare.

[R.a.14] Accedit auctoritas Gratiani, [fol. 268r] saltim ut ipse putat ese sententiam Augustini dist. 19. capite in canonicis, ubi ipse cum suis

\footnotetext{
${ }^{104} \mathrm{Ms}$. cunta.
} 
glosatoribus tenent quod omnes decretales sunt scripturae canonicae, nec possunt se excusare dicentes quod intelligunt improprie de scripturis canonicis. Nam Augustinus in illo loco unde sumptus est ille textus proprie loquitur de scripturis canonicis. Hic aperitur illustris quaestio ${ }^{105}$ de auctoritate ecclesiae. Et primo, videbimus quod possit ecclesia circa scripturam canonicam et $2^{\circ}$. comprobabimus auctoritatem ecclesiae ad auctoritatem sacrae scripturae.

[R.a.15] Quoad primum constituam 5. propositiones, etc. $1^{\text {a }}$. Christus redemptor noster quicquid revelavit ecclesiae pertinens ad fidem revelavit per apostolos ita quod ecclesia tota quae fuit a tempore apostolorum usque ad finem seculi non potest aliud tenere de fide nisi quod apostoli praedicaverunt vel explicite vel implicite vel in doctrina quam ipsi approbaverunt tamquam de fide. Haec conclusio probatur primo ex ipso nomine apostoli, quod idem ${ }^{106}$ valet quod missus. Quo nomine censentur solum illi 12. qui particulariter missi sunt ad praedicandum doctrinam Christi iuxta illud apostoli 2ae. ad Cor. 5. Pro Christo legatione fungimur tanquam Deo exhortante ${ }^{107}$ per nos. $2^{\circ}$. Comprobatur ex ipsa eorum electione Luc. 9. et Matth. 10. Convocatis Iesus 12. Apostolis dedit illis potestatem et virtutem super omnia daemonia et ut languores curarent, et misit illos praedicare verbum Dei. Et Matth. ultimo. Euntes in mundum universum, docete omnes gentes baptizantes eos, ubi omnes doctores notant proprium esse apostolorum et ad illos pertinere solum praedicare doctrinam Christi.

[R.a.16] Et ideo Ioannis 14. illis particulariter promissus est Spiritus Sanctus qui doceret eos omnem veritatem et Lucae ultimo stans in medio eorum dixit: Vos testes estis eorum quae in me complecta sunt et ego mittam promissum Patris mei in vos, vos autem sedete in civitate donec induamini virtute ex alto. Quem locum citat Lucas Actuum $1^{\circ}$. Ecce illis particulariter promissus est Spiritus sanctus tanquam testibus Christi et ita illis particulariter est missus, ut habetur Actuum $2^{\circ}$. Sed forte quis dubitat haec testimonia non satis intentum probare, nam episcopi succedunt apostolis ut auctor est Augustinus super illud Ps. $44^{108}$ pro patribus tuis nati sunt tibi filii, et habetur canone quorum vías 68 . distinctione et in concilio florentino. Ergo quicquid in evangelio dicitur proprie de apostolis communiter intelligendum est de omnibus episcopis. Et sic videtur quod saltem concilium potest facere scripturam sacram.

[R.a.17] Respondetur verum esse quod episcopi succedunt apostolis, non tamen ad condendum novam fidem, sed ad exponendum illa quae docti sunt ab

\footnotetext{
${ }^{105}$ Ms. quo.

${ }^{106}$ Ms. quidem.

${ }^{107}$ Ms. Exortante.

${ }^{108}$ Ms. 49.
} 
apostolis et ad gubernationem ecclesiae, ita quod sicut apostoli nihil potuerunt praedicare nisi quod Christus docuit illos, ita nec ecclesia potest tenere nisi quae docta est per apostolos. Unde apostolus 1ae. ad Cor. 12. distribuens officia membrorum ecclesiae distincte dixit: Posuit quosdam apostolos, $2^{\circ}$. prophetas, deinde doctores. Apostoli et prophetae revelationes inmediate recipiunt, sed doctores illa exponunt quae apostolis revelavit.

[R.a.18] Et confirmatur haec nostra solutio. Nam si episcopi succedentes apasto lis [fol. 268v] vel electi ab apostolis haberent potestatem quam habent apostoli, scilicet ut dictata sua haberent auctoritem divinam praedicandi doctrinam novam, non opus fuisset Matthiam subscribi loco Iudae per inmediatam electionem a Deo, sicut habetur Actuum $1^{\circ}$. Oportet (inquit Petrus) ex his viris qui ${ }^{109}$ nobiscum sunt congregati in omni tempore quo intravit et exiit inter nos Dominus incipiens a baptismate Ioannis usque in diem qua assumptus est a nobis testes resurrectionis eius nobiscum fieri. Ecce testem oculatum dicit eligendum esse, et illum quidem divinitus, ita praedicati sunt Deum ut ipse eligeretur. Ergo ipsi non habent auctoritatem apostolorum.

[R.a.19] Et confirmatur $2^{\circ}$, quia per opera pseudoapostoli moliebantur apud Galatas Paulum non esse verum apostolum quia non erat electus a Christo et ideo dicebant non esse habendam pro fide praedicationem eius. A quorum ipse calumnia sese compurgat comparando se aliis apostolis, et ideo incipit Paulus apostolus non ab hominibus nec pro homine sed per Iesum Christum et Deum Patrem qui suscitavit eum a mortuis. Quorsum haec si alius quam apostolus haberet auctoritatem rectificandi fidem Christi. Unde apostolis ${ }^{110}$ tribuit Christus proprietates quae sibi erant propriae Ionn. 20. Sicut misit me Pater et ego mitto vos. Et Ioann. 8. de se dicit: Ego sum lux mundi. Et Matth. 5. dicit vos estis lux mundi, et dicit eos esse super candelabrum ut luceant omnibus qui in domo; id est, qui in ecclesia sunt; illos esse sal terrae et civitatem supra montem positam, quod etiam Christus opere ipso ostendit cum legem non immediate toti populo sed solis apostolis primo promulgavit per quos per orbem erat praedicanda, nam cum ascendisset in montem dicit Mathaeus quod accesserunt ad eum discipuli eius et aperiens os suum docebat eos dicens: Beati pauperes, quod Lucas etiam insinuavit dicens quod elevatis oculis in discipulos suos dicebat: Beati pauperes, instruens illos qui aliis essent praedicaturi, quod Paulus $1 \mathrm{ae}$. ad Cor. $2^{\circ}$ docet dicens de sapientia divina quam nemo principum huius seculi cognovit. Nobis autem (inquit) revelavit Deus per Spiritum Sanctum.

\footnotetext{
${ }^{109}$ Ms. quod.

${ }^{110}$ Ms. apostolus.
} 
[R.a.20] Habemus ergo solos apostolos esse per quos Christus revelavit inmediate ecclesiae fidem suam, sed adiecimus in conclusione quod revelavit per solos apostolos vel per eos qui recepti et probati sunt ab apostolis, quod diximus propter Marcum et Lucam, unde Hieronymus in de viris illustribus: Et omnes doctores dicunt quod Marcus scripsit quidquid a Petro doctus est et Lucas instruente Paulo a Deo ut sint qui suspicantur ut quando apostolus dicit ad Timoth. 2ae. capite $2^{\circ}$. secundum evangelium meum, intelligit de evangelio Lucae sed hoc valeat quantum potest.

[R.a.21] Est tamen hic dubium utrum Marcus et Lucas fuerunt inmediate inspirati adeo ut, sicut apostoli, ad scribendum. Dicimus hic tria. Primum, quod fuerunt inspirati. Nam si solum fuissent inspirati per apostolos, non reputaret ecclesia evangelia eorum esse sua, sed potius apostolorum, quorum illi essent sicut notarii quemadmodum epistolam ad Romanos non ducit ecclesia pro epistola Tertii, [fol. 269r] sic enim vocabat notarium ${ }^{111}$ apostolus qui scripsit epistolam ad Romanos ut habetur ad Romanos ultimo, sed pro epistola Pauli licet ipso dictante Tertius scripserit. Ita ergo evangelia Marci et Lucae non reputarentur sua nisi ipsi tanquam veri auctores scripsissent. $2^{\circ}$. dico quod fuerunt forte inspirati [per inspirationem apostolorum]. $3^{\circ}$. dico sub censura hoc latius intelligentium quod fuit necessarium apostolos aprobasse sua evangelia ut haberentur pro canonicis. Alias ecclesia non potuisset habere pro canonicis nisi credidissent apostolis approbata. Haec sequuntur ex dictis quae diximus in robatione conclusionis quibus utcumque probavimus per solos apostolos Christum revelasse fidem.

[R.a.22] Et confirmatur auctoritate Augustini, qui hoc ipsum videtur sentiré libro $1^{\circ}$. de consensu evangeliorum ne putaretur quod attinet ad praecipiendum evangelium interesse aliquid utrum illi annuncient qui Dominum in carne apparentem secuti sunt, an hii qui ex illis fideliter comperta crediderunt divina providentia, procuratum est ut etiam his qui apostolos sequebantur quasi non essent recipiendi nisi apostoli comprobarent [hic sunt Marcus et Lucas]. Et capite $2^{\circ}$. dicit quod propterea ecclesia locavit eos inter Matthaeum et Ioannem ut ab utroque latere committerentur. Et lib. 4. capite 8. reddens rationem quare ecclesia accepit Lucam et Marcum et alios reiecit dicit, quia eo tempore scripserunt quo non solum ab ecclesia, verum ab ipsis in carne viventibus apostolis probare potuerunt, sed ipse divus Lucas huic conclusioni attestatur. Quoniam multi (inquit) conati ${ }^{112}$ sunt ordinare narrationem quae nobis sunt rerum complete sicut tradiderunt nobis, visum est et mihi exordium tibi scribere. Immo Augustinus lib. 18. contra Faustum capite 4. dicit quod

\footnotetext{
${ }^{111}$ Ms. notarius.

${ }^{112}$ Ms. cognati.
} 
Paulum ipsum nunquam recepisset ecclesia nisi ipse invenisse ${ }^{113}$ apostolos in carne viventes, quibus communicando et conferendo evangelium suum eiusdem societatis esse appareret. Et ex hoc sumenda est una regula qua utitur ecclesia in recipiendis libris canonicis. Omnis enim liber qui receptus est ab ecclesia tanquam canonicus pertinens ad novum testamentum tenendum est pro certo quod vel est apostoli vel receptus ab apostolis.

[R.a.23] Ecce 1am. conclusionem; scilicet. quod quidquid Christus revelavit ecclesiae pertinens ad fidem revelavit per apostolos, quam conclusionem asserebat Augustinus lib. $1^{\mathrm{o}}$. de consensu evangeliorum capite ultimo. Quidquid ille, scilicet Christus, de suis factis et dictis nos legere voluit, hoc scribendum illis, scilicet apostolis, tanquam suis manibus imperavit. Et Hieronymus in minori breviatione exponens illud Ps. 86. Dominus narravit in scripturis populorum, sed addidit principium horum quae fuerunt in ea. Non (inquit) qui sunt in ea sed principum qui fuerunt in ea, nempe apostolorum, ubi notat Hieronymus quod totus canon novi testamenti sit apostolorum vel saltim ab illis receptus.

[R.a.24] Huic 1ae. conclusioni apponimus 2am., scilicet quod id dictum est de apostolis in novo testamento, sentiendum est in veteri de prophetis. Non enim poterant quidquam tamquam de fide tenere nisi quod esset illis revelatum per prophetas. Quod nos docet Paulus ad Hebraeos $1^{\circ}$. Multipharie multisque modis olim loquens in prophetis, novissime autem diebus his locutus est nobis in filio. Quasi dicat id quod nunc loquitur in filio per apostolos, tunc loquebatur [fol. $269 \mathrm{v}$ ] per prophetas. Et ad Ephe. $2^{\circ}$. per prophetas et apostolos vocant fundamentum ecclesiae. lam non estis hospites et advenae sed estis cives sanctorum et domestici Dei superaedificati, etc. Ac si dicat Christum ese fundamentum ipsum utriusque testamenti et per prophetas et apostolos ese fundamenta quae fundantur ${ }^{114}$ in primo fundamento. Unde Augustinus super illud Ps. 86. Fundamenta eius in montibus, etc. pulchre exponit generaliter Christus in hoc quod dicitur lapis angularis qui est in firmitate aedificii, est primum fundamentum, nam quod in aedificiis terrenis fundatur, profundius subiicitur egregio in spirituali aedificio, fundamentum est in supremo loco a quo alia pendent fundamenta, unde Christus in evangelio Matth. 5. Docuit apostolos succedere prophetis ubi praemuniens ipsos $\mathrm{ad}^{115}$ tollerantiam persecutionum dixit: Sic enim persecuti sunt prophetas qui fuerunt ante vos.

\footnotetext{
${ }^{113}$ Ms. invenisse.

${ }^{114}$ Ms. fundatur.

115 Ms. a.

EMM = EHRLE, F. (MARCH, J. M.), Los manuscritos vaticanos de los teólogos salmantinos del siglo XVI. De Vitoria a Báñez: Estudios Eclesiásticos 9 (1929).
} 
Quocirca divus Petrus in $1^{\circ}$. capite 2ae. canonicae quo iudaeis perspicatius exprimeret auctoritatem apostolicam comparat ${ }^{116}$ prophetis. Habemus, inquit, firmiorem propheticum sermonem cui bene facitis attendentes sicut lucernae in caliginoso loco.

[R.a.25] Et ideo ipsi ${ }^{117}$ evangelistae usi sunt saepe auctoritatibus prophetarum. lmmo Christus ipse redemptor noster discipulis euntibus in Emmaus per expositionem prophetarum manifestavit mysteria ${ }^{118}$ redemptionis ${ }^{119}$. Sed ut vera sit ista conclusio extendemus nomen prophetiae ad legem et psalmos, quae tria distinguit redemptor noster in Lucae ultimo. Necesse est (inquit) implere omnia quae scripta sunt in lege Moysi et prophetis et psalmis de filio hominis ${ }^{120}$. Ergo quod per prophetas et apostolos revelavit Deus fidem utriusque testamenti. Unde Ambrosius libro $2^{\circ}$. de paenitentia capite $5^{\circ}$. Apostoli (inquit) et prophetae os Dei.

[R.a.26] $3^{\text {a }}$ conclusio est. Non referebat ad fidem ecclesiae scripto an solo verbo revelaretur fides nisi ut firmius maneret in memoria. Volo dicere non ese minoris auctoritatis dicta apostolorum licet Ecclesia solo verbo teneret illam. Haec ergo est contra istos haereticos modernos qui putant nihil ecclesia posse tenere de fide nisi quae est in sacra scriptura. Probatur conclusio paucis. Aliquando fuit ecclesia sine scriptura ut puta antequam Matthaeus aut Paulus scripsissent, et tunc tenebat tanquam de fide illa quae postea scripserunt. Immo, postquam Ioannes, qui fuit ultimus, scripsit. Adiecit in calce sui evangelii: Sunt et alia multa quae fecit Iesus quae si scribantur per singula nec ipsum arbitrar mundum capere posse eos qui scribendi sunt libros. Christus nusquam legitur praecepisse apostolis scribere quicquid, sed: Ite (inquit) et docete omnes gentes. In hoc quod dixit ite, insinuavit quod verbo praesentes deberent docere et non absentes per scriptum. Et confirmatur hoc quia Paulus ut est verisimile aliquas epistolas forte scripsit absentibus quas si posset praesentialiter adesse non scripsisset, quod insinuat ad Roma. $1^{\circ}$. Nolo vos ignorare fratres, quia saepe posui venire ad vos et prohibitus usque adhuc. Et sic ${ }^{121}$ videtur scripsisse epistolam quia non poterat venire, et ideo si

\footnotetext{
${ }^{116}$ Ms. compara.

${ }^{117}$ Ms. ipsae.

${ }^{118}$ Ms. misteria.

${ }^{119}$ Ms. redentionis.

${ }^{120}$ Ms. coloca al margen de nuevo hominis. Es que, al parecer, lo escrito dentro del texto podía no ser rectamente entendido como hominis.

${ }^{121}$ Ms. si.
} 
venisset verbo docuisset ${ }^{122}$ illa quae scripto docuit, quod esset subinde [fol. 270r] de fide. Unde 2ae. ad Thesalo. $2^{\circ}$. State (inquit) et tenete traditiones quas didicistis sive per sermonem sive per epistolam. Irenaeus distinctio 9. capite 4. dicit quod multi barbari sine caracteribus tenent fidem.

[R.a.27] $3^{\circ}$ arguitur, quia lex nova erat promissa, quae non in tabulis lapideis sed in cordibus hominum scriberetur ut habetur Ieremiae 31. Dabo (inquit) legem meam in visceribus eorum et in corde eorum scribam eam. Et apostolus $2 \mathrm{ae}$. ad Cor. $3^{\circ}$. Epistola estis Christi ministrata a nobis et scripta non atramento, sed spiritu Dei vivi. Non in tabulis lapideis sed in tabulis cordis carnalibus. Unde Chrisostomus in prologo super Matthaeum inquit: Oportuerat nihil nos indigere auxilio litterarum sed tam mundam exhibere ${ }^{123}$ vitam ut vice illarum gratia Spiritus Sancti uteremur; et deinceps docet propter malitiam hominum scriptam esse legem litteris, nam prius antiqua praecepta dedit Deus patribus Abraham, Isaac et Iacob non scripto sed in cordibus quae munda tunc habebant sed crescente malitia hominum in tempore Moysi scripta est in tabulis lapideis.

[R.a.28] Eodem modo ita in novo testamento. In primitiva ecclesia non fuit statim scriptura, quia lex scribenda erat in cordibus per Spiritum Sanctum, sed quando inceperunt pseudoapostoli, ceperunt scribere, et ideo quando Matthaeus abscedere volebat a iudaeis, rogatus ab illis qui crediderant. Reliquit illis in scripto praedicationem suam ut refert illic Chrisostomus et Heronymus in prologo super Matthaeum. Non ergo erat propter fidem necessaria scriptura. Sed est dubium circa istam 3am. conclusionem, utrum licet non fuisset necessarium propter fidem, nihilominus in rei veritate scripta sunt iam omnia quae sunt tanquam de fide tenenda, vel utrum sint aliqua tanquam de fide in ecclesia quae solo verbo durant a tempore Apostolorum. Hic distinguamus certa a dubiis.

[R.a.29] Sit $1^{a}$ propositio. Licet aliqua essent nondum scripta in ecclesia, dummodo ecclesia teneret tanquam tradita ab apostolis essent perinde tanquam de fide tenenda ac si essent scripta in evangelio. Haec dixerim contra istos haereticos oppositum dicentes, et hoc probatum est in $3^{\text {a }}$ conclusione principali. 2 um. dictum sit quod non est dubium esse in ecclesia multas traditiones apostolorum quae non sint scripta in canone et sunt tenendae tanquam apostolorum licet non sint omnino de fide quemadmodum evangelium. Hoc docet Origenes homilia 3. super Numeros ubi dicit multas esse caerimonias in ecclesia quas a pontifice Christo et filiis eius traditas et conmendatas suscepimus ut orare genibus flexis ad orientem, exorcismi et cathecismi in baptismo et

\footnotetext{
${ }^{122}$ Ms. docuisse.

${ }^{123}$ Ms. exhivere.
} 
aliae id genus caerimoniae in administrandis sacramentis, quas verisimile est a tempore apostolorum enarrasse in ecclesia. Idem dicit Dionysius capite $1^{\circ}$. ecclesiaticae hierarchiae; scilicet quod doctrinas et praeceptiones Apostoli multas ${ }^{124}$ partim scriptis, partim non scriptis, tradiderunt nobis. Item Cyprianus et Hylarius quos refert Rofensis veritate $9^{\mathrm{a}}$ adversus Lutherum.

[R.a.30] 3 um. dictum est quod posset ecclesia aliquid [fol. $271 \mathrm{v}$ ] tanquam de fide per articulos exprimere quod non sit expressum et sit implicite contentum in sacra scriptura. Hoc probabimus statim conclusione $5^{\mathrm{a}}$. $4 \mathrm{um}$. dictum est veniendo ad punctum quod forsan tanquam de fide proprie nihil tenet ecclesia quae non sit vel implicite vel explicite in sacro canone, sed est de per accidens quod sint scripta ornnia, quia nihilominus essent de fide, et dicimus quod providentia Spritus Sancti factum est ut omnia munda, omnia mundarentur scripto propter haereticos homines. Hoc sic mihi persuadeo. Primo, quia eccclesia propter sacrum canonem nihil tenet tanquam proprie de fide nisi 14. articulos fidei et illi ornnes sunt in sacro canone vel expresse vel implicite. $2^{\mathrm{a}}$, confirmamus hoc dictum auctoritatibus Augustini et Hironymi supra citatis. Ait enim Augustinus: Quidquid Christus de suis factis et dictis nos legere voluit, hoc scribendum apostolis tanquam suis manibus tradidit. Et Hieronimus super illud in scripturis populorum dicit quod Dominus narravit non verbo sed scriptura. Et sic videtur quod tota fides sit in scriptura iam posita, cui sententiae videtur subscribere Ubaldensis, tomo $1^{\circ}$ libro $2^{\circ}$ capite 20 . Et 21., nam dicit quod non potest ecclesia novam scripturam canonicam condere, et intellexit ${ }^{125}$ quod non potest declarare esse aliam scripturam apostolorum nisi quae iam est recepta.

[R.a.31] $4^{\text {a }}$ conclusio principalis est quod ecclesia non potest facere scripturam canonicam. Haec sequitur ex prima, nam si quidquid Deus revelavit ecclesiae revelavit per apostolos, non potest ipsa aliam novam condere tanquam de fide. $5^{\text {a }}$ conclusio et ultima est quod ecclesia accipiendo pro tota ecclesia exclusis apostolis habet auctoritatem determinandi dubia quae sunt in sacra scriptura et exponendi novas articulos fidei eliciendo illos ex sacra scriptura. Haec late patet apud auctores qui scripserunt contra Ubicleftistas, et nunc adversus lutheranos, qui haeretici putant nullum dubium ecclesia posse terminare, sed quod est expectanda revelatio Spiritus Sancti ut dicebat Ubicleft sermone 45. referente Ubaldense tomo $1^{\circ}$ libro $2^{\circ} \mathrm{c}$. 19. Et quia non intendimus hic disputare contra istos haereticos, paucis declarabimus conclusionem.

[R.a.32] Primo, Matthaei 28. Ecce ego vobiscum sum ornnibus diebus usque ad consummationem seculi, et Ioannes 14. Ego rogaba Patrem et alium

\footnotetext{
${ }^{124}$ Ms. multas.

${ }^{125}$ Ms. intellixit.
} 
Paraclitum dabit vobis ut maneat vobiscum in aetemum. Ad quid promisit se et Spiritum sanctum nobiscum permansuros nisi potissimum ad exponendum sacram scripturam quam ipsi revelaverant? Et ratione probatur adversus istos, quia Christus salva conditione hominum non potuit doctrinam adeo clarissima tradere quia a diversis varie intelligeretur. Nam haec est conditio humana ut sicut tot sensus quot capita. Unde ex sacra scriptura male intellecta variae haereses creverunt in ecclesia, ut ex illo (Pater maior me est) conclusit Arianus Filium non esse [fol. 271r] consubtantialem Patri et ex alio: Ego et Pater unum sumus, colligit contrarium Sabellius: non esse personaliter distinctos. Ergo necesse fuit quod maneret in ecclesia certa regula ad illa dubia terminanda. Alias posset ${ }^{126}$ deficere fides contra promissionem Christi: Ego rogaba pro te ut non deficiat fides tua. Et hanc regulam non potest alius fingi nisi vel papa qui est vicarius Christi, vel ecclesia legitime congregata cum papa. De hoc non disputamos modo.

[R.a.33] Nam si esset expectanda nova ${ }^{127}$ revelatio, ut dicebant illi haeretici, vel erat expectanda ut singulis suppositis ecclesiae fieret revelatio, vel quod fieret uni cui alii crederent. Non primum, quia hoc esset fatuum dicere: quod singuli deberent expectare revelationem. Et si 2 um., vel esset de fide quod ille cui fit revelatio non posset decipere alios, vel non. Si non esset de fide, quam certitudinem habemus quod ille non mentiretur? Nam Mahometus etiam asserebat sibi esse a Deo revelatam sectam suam. Si autem esset de fide quod ille non posse ${ }^{128}$ decipere, certe non potest esse alius nisi vel vicarius Christi cui promisit Christus quod non deficeret fides sua, vel tota ecclesia de qua dixit quod ubicumque fuerint duo vel tres in nomine eius congregati, ibi esset in medio eorum. Hoc etiam confirmatur ex usu ecclesiae quae in concilio nicaeno et in Constantinopolitano ${ }^{129}$ determinavit certos articulos contra diversos haereticos tanquam de fide. Late corroborat hanc conclusionem dominus Ubaldensis tomo $1^{\circ}$. libro. $2^{\circ}$. capite 19 . Unum tamen volo admonere quod asserit illic capite 22 . Ait enim quod licet ecclesia potuit antea condere novos articulos, tamen iam non potest quia iam adducta est ad aetatem perfectam.

[R.a.34] Hoc tamen bona venia gravissimi doctoris dixerim. Non video quomodo sit verum. Nam si propter necessitatem diversorum haereticorum in ecclesia illi articuli sunt conditi, ut puta de consubstantialitate divinarum personarum, de divinitate Christi, nescio quare si modo insurgant novae

\footnotetext{
${ }^{126}$ Ms. posse.

${ }^{127}$ Ms. noba.

${ }^{128}$ Ms. posse.

${ }^{129}$ Ms. Epheso.
} 
haereses, quare non possint condi novi articuli, ut v. g. si nunc in concilio futuro determinaretur tanquam articulus quod Christus est realiter in sacramento contra illos haereticos qui hoc negant ecclesiae. Ergo de illo dubio $3^{\circ}$, utrum ecclesia posset ${ }^{130}$ condere sacram scripturam, negamus enim quod possit. Ex quo sequitur corollarium contra illum textum Gratiani falso desumptum ex Augustino dist. 19. capite in canonicis, et contra canonistas, quod propter ipsum sunt decepti dicentes quod decretales et concilia sunt scripta canonica.

[R.a.35] Sequitur in contrarium quod nec decretales nec concilia sunt scriptura canonica. Hoc satis probatum est iam. Et adhuc confirmatur, nam scriptura canonica invariabilis est et inmutabilis omnino, sed decretales et acta concilii possunt et debent iuxta temporum varietatem mutari. Et confirmatur hoc quia acta concilii sunt nonumquam de rebus non tanti momenti, ut puta pertinentibus ad aliquas caerimonias ecclesiae vel personarum ecclesiasticarum, quae perinde solent per consuetudinem abrogari. Immo quae sunt [fol. $271 \mathrm{v}$ ] maioris momenti abrogantur, ut antiquae paenitentiae quae antiquitus gravissime iniungebantur pro peccatis. lmpietas est dicere quod sacra scriptura per aliquam consuetudinem abrogetur. Et de decretalibus est adhuc apparentia minor, nam licet de concilio legitime congregato cum papa communis sit omnium consensum ut errare non posset ${ }^{131}$, tamen non habetur pro haeretica opinio dicentium quod papa potest errare etiam ut papa, licet iam forte non sustineret papa hanc opinionem. Sed quid pluribus opus est? Nusquam, vel in concilio vel in decreto pontificis, nec apud aliquem sanctum patrem, connumerantur concilia vel decretales inter libros canonicos, ut est videre in concilio laodicaeno, carthaginensi, florentino, ubi libri canonici numerantur. Et Gelasius in canone sancta ${ }^{132}$ romana 15. distinctione post sacram scripturam collocat sacra concilia.

[R.a.36] Unde ad textum Gratiani in capitulo in canonicis dicimus quod est falso et mendosissime desumptus ab Augustino, nam verba Augustini $2^{\circ}$ de doctrina Christiana capilulo 8., unde textus ille desumptus est: Sic habentur in canonicis scripturis ecclesiarum catholicarum. Quamplurimum indagatur scripturarum auctoritas ${ }^{133}$. Sequitur: Inter quas, scilicet ecclesias, sane illae sunt quae ${ }^{134}$ apostolica sedis litterae et ab ea aliae meruerunt accipere. Relativum quas; apud Augustinum refert ecclesias et apud Gratianum refert epistolas; et

\footnotetext{
${ }^{130}$ Ms. posse.

${ }^{131}$ Ms. posse.

${ }^{132}$ Ms. santa.

${ }^{133}$ Ms. aucotritatem.

${ }^{134}$ Ms. quas.
} 
ideo compulsus est totam litteram pervertere ut palam est conferenti textum Augustini et textum Gratiani, et ideo lapsus est in hunc errorem ut non solum epistolas romanae ecclesiae crederet esse canonicas, sed etiam quas romana ecclesia recipit ab aliis ut si aliquis episcopus scripsit papae illa habebitur pro canonica. Sed tamen postquam cepit esse apud ipsos, opinio erit semper licet videant manifestissimum errorem in littera, et licet Gratianus habuisset ${ }^{135}$ mendosum librum, debuisset notare verba quae sequuntur Augustini, nam statim declarat in particulari qui sunt libri canonici et recenset omnes libros qui sunt in biblia, nec meminit conciliorum nec decretalium. Sed satis est de hoc ad momentaneam declarationem.

[R.a.37] Ad argumentum quod ecclesiae concilia et decreta sint scriptura canonica dictum est supra ad auctoritatem libri canonici non opus esse alia revelatione quam motione Spiritus Sancti speciali et manutenentia ne scriptor posset errare. Sed ita concurrit cum concilio. Ergo. Ad hod dicimus quod ad auctoritatem libri canonici requiritur inmediata revelatio, id est quod non praecedat per aliam revelationem nec more humano. Ita enim scripserunt evangelistae, non quod colligerent ea quae scripserunt ex alia scriptura per disputationem et inquisitionem. Sed concilium non recipit revelationem inmediatam, sed requiritur a Spiritu Sancto ut exponendo sacram scripturam vel inde eliciendo aliquas conclusiones non errent. Sed contra, quia etiam evangelistae [fol. $172 \mathrm{r}$ ] usi ${ }^{136}$ sunt testimoniis prophetarum. in concilio Actuum 15. Ad confirmanda decreta concilii etiam usi sunt testimoniis scripturarum ut puta Amos 9. Post haec revertar et reaedificabo tabernaculum David. Et hoc non obstante illud concilium est sacra scriptura. ldem Paulus ad Gala. 4. exponit illud quod Abraham habuit duos filios, exponit tanquam allegorice de duobus testamentis et ille sensus habetur pro canonico non alias, nisi quia regebatur a Spiritum sancto ne errare posset in illa expositione. Ergo cum etiam non posset ${ }^{137}$ errare adminus si utatur sacra scriptura, sequitur quod poterit exponere sacram scripturam taliter quod illa expositio sit scriptura canonica.

[R.a.38] Dicimus ad hoc quod apostoli et evangelistae utebantur testimonis prophetarum de per accidens ita quod nihil minoris auctoritatis haberent licet nihil citassent, sed citabant ad condendas scripturas sicut Christus ipse utebatur

${ }^{135}$ Ms. habiusse.

${ }^{136}$ En el folio $271 \mathrm{v}$ se indica que la palabra primera del folio siguiente (272r) es usi; pero se escribió la primera palabra $u b i$. No hay duda de que es una equivocación y debía haberse escrito $u s i$, que es lo que aquí se pone. Además, alguien colocó una $s$ encima de la b de ubi, como para llamar la atención de que debía leerse: usi.

${ }^{137}$ Ms. posse. 
etiam eisdem scripturis, vel ad confundendos iudaeos, vel ad condendum quomodo omnia in figura contingebant illis. Sed ecclesia debet uti scriptura de per se ita, quia si concilium vellet aliquid determinare non modo humano disputando circa sacram scripturam, certe errasset, et sic sua revelatio non est inmediata. Et per idem dicimus ad 2 um. quod Paulus non elicuit illum sensum allegoricum more humano per aliam scripturam. Ecclesia tamen non posset exponere unam scripturam nisi per aliam, vel utendo disputationibus et rationibus naturalibus sapientium, et ideo sua scriptura non est canonica licet sit expositio sacrae scripturae nisi determinet illum tamquam articulum contentum in sacra scriptura.

[R.a.39] Ex quo sequitur alia differentia. Quod in quocumque sensu apostolus citat aliquam auctoritatem, est de fide quod ille est verus sensus. Non tamen sic de ecclesia nisi determinet tanquam articulum. V. g. in concilio florentino citatur illud Iacobi: Infirmatur quis in vobis, inducat presbíteros ecclesiae ad corroborandum sacramentum extraemae unctionis ${ }^{138}$. Non est de fide quod ille sit sensus auctoris licet sit determinatio ecclesiae quod illud sit verum sacramentum. Ultimum argumentum potest fieri hic quod videtur ecclesia tenere multa de fide quae non sunt in canone ut perpetuam virginitatem Virginis, purgatorium, et alia id genus. Dicimus quod omnia illa sunt in sacra scriptura iuxta expositionem ecclesiae temporibus apostolorum, sed hoc longiorem tractatum exposcit.

[R.a.40] Habemus iam primam partem 3i. dubii principalis de auctoritate ecclesiae circa sacram scripturam, nempe quod non potest illam condere sed declarere. Restat disputare de $2^{\mathrm{a}}$, scilicet de comparatione auctoritatis ecclesiae ad auctoritatem sacrae scripturae, scilicet utrum sit maioris auctoritatis sacra scriptura an ecclesia. Nam hoc est positum in controversia apud doctores. Et sunt de hoc tres opiniones. Duae extremae et $3^{\mathrm{a}}$, quae videtur ambas conformare. Prima opinio est domini Abulensis in sua introductione super Matthaeum quaestione 13. dicentis ecclesiam esse maioris auctoritatis quam sacra scriptura. Ratio eius est, quia Aristoteles $1^{\circ}$. Posteriorum: [fol. 272v] propter quod unumquodque tale et illud magis. Sed evangelio credimus propter ecclesiam. Ergo. Et probat minorem, nam certitudo (inquit) et auctoritas evangelistarum non evenit eis propter se ipsos sed propter ecclesiam, nec credimus evangelistis quia sunt Matthaeus, Marcus, sed quia ecclesia asserit eos vera dicere et iubet eis credi. Ecce comparat residuum ecclesiae evangelistis et dicit quod sunt minoris auctoritatis. Et probat $2^{\circ}$, quia etsi sciretur credendum esse Matthaeo, tamen non crederemus hunc librum esse Matthaei nisi ecclesia diceret. Et

\footnotetext{
${ }^{138}$ Ms. untionis.
} 
confirmatur hoc per illud Augustini contra epistolam fundamenti Manichaei capite 5. Evangelio non crederem nisi me catholicae ecclesiae commoveret auctoritas. Et subiungit gravissima verba, nempe quod ecclesia est maioris auctoritatis quam quicumque evangelista aut propheta, immo quam mille evangelistae aut prophetae simul sumpti.

[R.a.41] $2^{\text {a }}$ opinio est in alio extremo domini Caietani opusculo de comparatione papae et concilii capite $4^{\circ}$. Dicit enim quod maioris auctoritatis est Ioannes evangelista quam papa, et nomine papae intelligit totam ecclesiam. Et si Ioannes tempore Lini aut Clementis aliquid dixisset contra sententiam eorum in his quae pertinent ad fidem, praevaleret sententia Ioannis, sicut praevalet modo evangelium sententiae totius ecclesiae. Et ratio est, quia solis apostolis dedit Deus auctoritatem condendi sacram scripturam. Non adducit aliam probationem, sed dominus Ubaldensis tomo $1^{\circ}$, libro $2^{\circ}$, capite 21 , pluribus confirmat hanc opinionem, nam prorumpit in haec verba, scilicet dicere decretum patrum in ecclesia maioris esse culminis et ponderis quam sit auctoritas scripturarum non tam videtur ineptum quam fatuum.

[R.a.42] $3^{\mathrm{a}}$ opinio est Ioannis Driedonis auctoris egregii libro $4^{\mathrm{o}} \mathrm{de}$ ecclesiasticis scripturis capite 4, ubi utitur hac distinctione. Dupliciter loqui possumus de ecclesia. Uno modo accipiendo pro tota ecclesia a tempore apostolorum includendo ipsos apostolos. Et sic ponit $1 \mathrm{am}$. conclusionem. Licet ecclesia habeat latiorem auctoritatem et ad plura se extendat quam sacra scriptura, ut ad remittenda peccata et condendas leges, tamen ecclesiae et scripturae eadem et aequalis est veracitas et vis et dignitas ut credantur. Et ratio est quia eodem spiritu quo condita est scriptura illuminatur ecclesia, immo aliquando fuit sine scriptura, et tamen ecclesia tantam auctoritatem habebat sicut et modo scriptura. $2^{\circ}$ modo accipitur ecclesia pro illa quae nunc est, vel quae fuit a tempore apostolorum excludendo apostolos. Et sic ponit $2 \mathrm{am}$. conclusionem. Ecclesia isto modo non est tantae auctoritatis sicut sacra scriptura nec sicut ecclesia primo modo. Probat, quia ecclesia isto modo innititur auctoritate apostolorum. Et in conclusione videtur convenire cum Caietano et ita ambo intelligunt illud Augustini: Evangelio non crederem nisi me ecclesiae conmoveret auctoritas, de ecclesia $1^{\circ}$ modo. Immo si acciperetur $1^{\circ}$ modo (inquit Driedo) contrarium dixisset Augustinus, scilicet quod hanc non crederem esse ecclesiam nisi evangelium assereret.

[R.a.43] Ad hanc conclusionem respondemus per sequentes propositiones. Prima propositio exordienda a distinctione [fol. 373r] Driedonis de ecclesia. Sit haec. Quando comparatur auctoritas ecclesiae ad auctoritatem sacrae scripturae, non debet accipi ecclesia ut includat apostolos in quantum apostolos; id est, in quantum habent auctoritatem condendi sacram scripturam. Probatur, quia tunc perinde est ac si comparetis testem ad suum testimonium, 
ut si quaeratis an imperator sit maioris auctoritatis quam veritas quam ipse asserit. Et sic nullus dubitat eiusdem esse auctoritatis asserentis veritatem et veritatem assertam.

[R.a.44] $2^{\mathrm{a}}$ propositio. Adhuc si sic fieret comparatio, forte est hoc particulare in apostolis quod testimonium eorum in his quae sunt fidei est maioris auctoritatis quam ipsi apostoli absolute et quam id quod a se asserunt. Nam non repugnat apostolo et confirmato non exercendo officium apostoli dicere mendacium iocosum, quia non repugnat ei $^{139}$ peccare venialiter, sed quae asserit circa fidem habent auctoritatem a Spiritu Sancto revelante, et $\mathrm{sic}^{140}$ habent maiorem auctoritatem quam apostoli absolute licet non quam apostolus exercendo officium suum, scilicet apostoli. Quare non debet fieri comparatio inter ecclesiam includendo apostolos et scripturas. Et confirmatur hoc, quia cum comparamus ecclesiam ad auctoritatem condendi sacram scripturam et per consequens distinguimus illam per apostolos in quantum conditores sacrae scripturae.

[R.a.45] $3^{\text {a }}$ conclusio. Accipiendo ecclesiam seclusa auctoritate condendi scripturam, nullo modo est maioris auctoritatis quam sacra scriptura, dico maioris veracitatis, seclusa auctoritate gubemandi fideles de qua modo non loquimur. Hanc assero salva auctoritate gravissimi doctoris Abulensis contra suam opinionem. Et probatur. Auctoritas et veracitas sacrae scripturae est auctoritas divina, nam iam probabimus esse per revelationem inmediatam Spiritus Sancti qui ut non falli, ita nec fallere potest. Ergo sacra scriptura habet summam auctoritatem qua non potest dari maior.

[R.a.46] Immo Deus non habet maiorem auctoritatem quam sacra scriptura, sicut non habet maiorem auctoritatem quam suum testimonium. Et ideo dicere quod ecclesia habet maiorem auctoritatem quam sacra scritura est dicere quod habet maiorem auctoritatem quam Deus, et hoc significavit Christus redemptor noster Matthaei 24. dicens: Caelum et terra transibunt, verba autem mea non transibunt. Nam cum caelum et terra sint firmissimae res omnium quam oculis nostris subiiciuntur, voluit dicere quod nihil potest comparari sacrae scripturae in firmitate et veracitate. Evangelizabimus ${ }^{141}$ vobis, anathema sit. Et cum dicit: nos, intellexi ecclesiam, immo se ipsum in quantum apostolum, et non contentus addidit: et angelus de caelo. Ergo sequitur quod, si tota ecclesia et omnes apostoli, dixissent nobis oppositum sacrae scripturae, non deberemus credere. Certe non potest in aliquo sensu defendi quod ecclesia sit maioris auctoritatis quam sacra scriptura. Et est argumentum Abulensis et commune

\footnotetext{
${ }^{139}$ Ms. ei (otra vez; es decir, repetido).

${ }^{140}$ Ms. si.

${ }^{141}$ Así en el manuscrito. Parece que falta algo al principio.
} 
in contrarium. Sacrae scripturae non credidissemus nisi propter ecclesiam asserentem. Ergo ecclesia est maioris auctoritatis.

[R.a.47] Respondemus quod illud antecedens potest habere triplicem sensum. [fol. 173v] Primus, quod credimus sacram scripturam, v. g. verbum caro factum est quia ecclesia asserit illud esse verum. Et iste sensus est falsus ut omnes concedunt. Nam non credimus illud nisi quia est revelatum a Deo. 2 us. sensus est quod credimus illud esse verum quia est revelatum a Deo, sed credimus esset revelatum a Deo quia ecclesia hoc dicit asserendo quod illud est evangelium Ioannis. Et hoc adhuc potest intelligi ${ }^{142}$ dupliciter. Uno modo quia ultima resolutio huius fidei fiat in auctoritatem humanam, ut est in opinione aliquorum quam existimat probabilem Scotus in 3. dist. 23. Dicunt enim isti quod credimus sacrae scripturae quia revelata est a Deo, sed credimus quod ecclesia non potest nos decipere dicendo quod haec sunt revelata. Dicunt, quia hoc asserunt predicatores et fidedigni et homines gravissimi et fide digni. Ratio et causa sic opinandi fuit istis ut evitarent circulum in respondendo. Nam si vos dicatis quod creditis verbum carnem factum esse quia est revelatum et creditis esse revelatum quia dicit ecclesia, et creditis quod ecclesia non fallit, quia est revelatum non posse fallere, probatis aliquid esse revelatum, quia est revelatum.

[R.a.48] Et sic ut hoc evitarent, dicunt quod standum et in auctoritate fide dignorum. Sed certe opinio haec est periculosa, nedum falsa, quia tunc sequitur quod fides non habet auctoritatem divinam quia tandem ultimo vos probatis articulum fidei quia dicunt fidedigni, quod est erroneum, nam totus mundus, maxime cum sit omnis homo mendax, non sufficit generare tam firmam fidem quantam tenemur adhibere sacrae scripturae, cui tenemur certius credere quam conclusioni demonstratae mathematice. Item quia si ego credo quia dicunt fidedigni, scilicet praedicatores, sequeretur quod si docerent oppositum, non crederem illud quomodo credo, contra illud Pauli ad Gala. $1^{\circ}$. iam citatum. Et ideo nos dicimus quod credimus scripturam esse veram quia est revelata, et credimus esse revelatam quia dicit ecclesia, et credimus ecclesiam non posse fallere propter ipsam fidem infussam interius inclinantem ad hoc, et propter inspirationem et auxilium Spiritus Sancti. Et haec est ultima resolutio fidei. Et sic in illo sensu falsum est quod credimus sacram scripturam ultimate propter ecclesiam.

[R.a.49] Si autem sit tertius sensus: quod credimus sacram scripturam non quia ecclesia asserit esse veram, sed quia asserit esse sacram scripturam, scilicet esse revelatam, nos concedimus antecedens, sed inde non sequitur quod sit maioris auctoritatis quam sacra scriptura, quia postquam iam credo quod est

\footnotetext{
${ }^{142}$ Ms. intellixi.
} 
sacra scriptura, firmius credam sacrae scripturae quam ecclesiae vel saltem non credam firmius ecclesiae quam sacrae scripturae. [fol. 274r] Exemplum est si sit nunc, v. g. homo magnae auctoritatis apud me, quem tamen non cognosco, ut si nunc viveret divus Hieronymus esset coram me, quem tamen non cognoscerem, diceret plebeius homo: ecce iste est Hieronymus, non inde sequitur quod ille sit maioris auctoritatis apud me quam Hieronymus, quia postquam credidi esse Hieronymum firmius credam dictis eius quam dictis alterius. Exemplum est in evangelio Ioannis $1^{\circ}$. de Andrea qui introduxit Simonem fratrem suum ad Iesum et de Philippo qui etiam introduxit Nathanael. Clarum est quod Nathanael credidit illum esse Christum propter auctoritatem Philippi, sed non subinde sequitur quod Philippus esset maioris auctoritatis apud Nathanael quam esset Christus. ltem, licet auctoritate ecclesiae credamus hanc esse scripturam Ioannis, non sequitur quod sit maioris auctoritatis quam scriptura. Simile est Ioannis $4^{\circ}$. de muliere samaritana quae nunciavit in civitate Christum advenire et samaritani crediderunt illum esse Christum propter mulierem, sed posteaquam sciverunt ${ }^{143}$ esse Christum, dicebant mulieri quia non propter tuam loquelam credimus. Habemus ergo quod non sequitur scripturam esse scripturam propter ecclesiam, ergo est maioris auctoritatis. Sed quaeritur e converso utrum saltim scriptura sit maioris auctoritatis quam ecclesia.

[R.a.50] Ad hod dubium etiam respondemus per propositiones distingüendo certa ab incertis. Prima propositio, uterque auctoritas est auctoritas divina, scilicet auctoritas ecclesiae ut distinguitur contra apostolos. Et auctoritas ista iam est probata quia ecclesia in his quae pertinent ad fidem non potest errare, quia ipse Spiritus sanctus qui locutus est per prophetas et apostolos regit et tenet ecclesiam ne erraret. $2^{\mathrm{a}}$ propositio. Quod sequitur ex ista. Eadem haeresis est negare actus concilii et negare sacram scripturam, id est haeresis eiusdem speciei quia utraque est negare testimonium Spiritus sancti. $3^{a}$ propositio est. Revelatio sacrae scripturae est inmediatior quam revelatio ecclesiae quia ut diximus, sacra scriptura est condita inmediate a Spiritu Sancto ipso, scilicet spirante, sed ecclesia non illuminatur nisi per sacram scripturam. Et sic habet se revelatio sacrae scripturae ad revelationem ecclesiae sicut principia ad conclusionem. Ex qua sequitur 4a . Quod possumus dicere testimonium sacrae scripturae esse magis certum quam testimonium ecclesiae eo modo quo Aristoteles dicit $1^{\circ}$. Posteriorum quod credimus magis principiis quam conclusioni. Sed certe illud magis nescio quid aliud sit nisi inmediatius, quia revera non est firmius assentire.

[R.a.51] Et ideo pono 5am. propositionem. Quod simpliciter dicendum est esse pares in auctoritate. Volo dicere quod si per impossibile ecclesia in

${ }^{143}$ Ms. civerunt. 
quantum ecclesia diceret aliquid et evangelista simul diceret oppositum, nec crederem ${ }^{144}$ ecclesiae nec scripturae. Et hoc non putetis quod male sonet in fide. Nam antecedens conditionalis implicat contradictionem, quia ecclesia nihil potest determinare nisi [fol. 174v] quod sequitur ex scriptura sacra et ex illa implicat quod sequatur aliquid contra ipsam. Sed dico per medium intrinsecum quod, si assererent duo contradictoria, neutri crederem ${ }^{145}$. Nam ita insinuat Paulus: Si nos vel angelus aliud evangelizaverit, anathema sit, id est non credatis. Sed est unum argumentum contra hanc conclusionem in epistola Iudae quia est ${ }^{146}$ canonica ut videbimus. Citatur liber Enoch ubi asseritur librum Enoch esse canonicum, et tamen quia ecclesia non habetur pro canonico non est habendus pro canonico. Ergo magis credendum est ecclesiae quam scripturae.

[R.a.52] Respondeo primo quod apostolus citans illum librum non perinde asserit esse canonicum, nam potuit citare etiam librum philosophiae naturalis. $2^{\circ}$ dicimus ut sentit Augustinus 18. libro de civitate capite 38. quod in illo libro potuit esse aliquid tanquam revelatum a Spiritu santo et aliquid additum humana ratione, et ideo ecclesia non recipit illum. Diximus in $5^{\text {a }}$ propositione si simul dicerent, nam si apostolus prius dicat aliquid et postea ecclesia vel idemmet apostolus dicat contrarium, credam primo quod iam firmatum est. Unde infero quod scriptura est nunc tantae auctoritatis quod si omnes apostoli modo dicerent oppositum, non crederem nisi scripturae, et hoc docet Paulus ad Gala. $1^{\circ}$. Sic ergo si ecclesia legitime congregata assereret mihi modo articulum tanquam de fide et postea apostolus diceret oppositum, crederem ecclesiae. E converso ad auctoritatem humanam, nam cum homines successive cognoscant res et mutentur in sua cognitione, quod ultimo asserunt habet maiorem auctoritatem, ideo autem quia est inmutabilis, si per impossibile duo contradictoria assereret successive, prius assertum habet maiorem auctoritatem. Ex quo sequitur intellectus illius dicti Augustini: Evangelio non crederem nisi me auctoritas ecclesiae commoveret. Non enim credo esse intelligendum, ut putant dominus Caietanus et dominus Driedo $^{147}$ de ecclesia includendo apostolos, quia tunc perinde esset ac si diceret: evangelio non crederem nisi apostoli me conmovissent, quod nihil est dicere.

[R.a.53] Item idem Augustinus illic volebat magnificare auctoritatem ecclesiae quam negabat Manichaeus. Et per consequens loquebatur de

\footnotetext{
${ }^{144}$ Ms. crederent.

${ }^{145}$ Ms. crederent.

${ }^{146}$ Ms. es.

${ }^{147}$ Ms. Driedonis.
} 
ecclesia sui temporis. Sensus ergo est: Evangelio non crederem, nisi ecclesia me moveret ad credendum quod est evangelium. Et ita exponit dominus Ubaldensis primo tomo $2^{\circ}$. capite $21.2^{\circ}$. sequitur ex dictis quod ecclesia ut distinguitur contra apostolos semper habet et habebit eandem auctoritatem. Nam sicut antequam esset scrip- [fol. 175r] tura, ecclesia sic accepta nihil poterat addere ad doctrinam apostolorum quam verbo praedicabant, sed poterat dubia definiré et articulos facere, eandem auctoritatem habet nunc circa scripturam, sed tamen ecclesia includendo apostolos qui etiam sunt membra ecclesiae etiam in quantum apostoli, non potest nunc modo quod potuit tunc per apostolos, quia non potest augere doctrinam fidei. Et hoc de primo dubio principali totius relectionis, nempe de auctoritate scripturae canonicae. De $2^{\circ}$ puncto et de aliis dicemus postea. Amen.

[R.a.54] Uni trinoque Domino sit sempiterna gloria. Amen.

\section{b) De cathalogo librorum sacrae scripturae (1537)}

[R.b.1] [fol. 254r] Relectio de catalogo librorum sacrae scripturae habita Salmanticae a nostro reverendissimo magistro fr. D. de Soto anno Domini 1537. Locus relegendus: Vidi in dextera Dei sedentis super thronum librum scriptum intus et foris. Apoc. $5^{\circ}$. Prima propositio. Ad ecclesiam catholicam, atque adeo ad summum pontificem, pertinet ${ }^{148}$ scripturas sacras in canonem referre, quae tamen non simul universas sed temporis successu in canonicas recepit. $2^{\mathrm{a}}$ propositio. Libri veteris instrumenti tametsi hebraei nonnullos a catalogo sacrorum exceperint, verum iam modo universi 44. qui in bibliis circumferuntur, canonicam auctoritatem obtinuerunt. $3^{\circ}$ et $4^{\circ}$. Esdrae exceptis cum libello qui Baruch inscribitur. $3^{\mathrm{a}}$ conclusio. Circa libros novi testamenti qui in bibliis habentur quanquam olim de quibusdam, etiam inter catholicos patres fuerit dubitatum, tamen modo circa errorem notam dubitare non licet quominus universi 27 in canone sint relati.

[R.b.2] In superiori relectione quam anno proximo de auctoritate sacrae scripturae habuimus tria polliciti sumus disputare. Primum, circa auctoritatem sacrae paginae, quanta videlicet ea sit et ad quos pertineat eam condere. Mox circa numerum librorum eius, quotnam scilicet quique sint libri canonici. Postremum, circa multiplices eius sensus, nempe quot atque adeo qui sensus in ea distinguantur. Atvero cum pro rei magnitudine fecunditateque vix tunc licuit primum absolvere, necessarium iudicavimus aliam vobis polliceri disputationem qua reliquas duas partes prosequeremur. Sed quia non statim ut

\footnotetext{
${ }^{148}$ Ms. pertinent.
} 
promisseram id prestiti, video iam modo gratiam temporis praeteriisse atque adeo mihi ${ }^{149}$ rem importunam facere dum anno iam integro intercepto hanc illi relectionem assuere molior. [fol. 254r] Verum enim vero longe absurdius a vobis, ut puto, iudicatus fuissem si rem tam dignam quae perficeretur infectam et truncamque relinquissem. Quam ob rem ${ }^{150}$ nihil aliud quam opere praetium vobis fore existimatus si rem iam fere oblivioni sepultam denuo exsuscitemus revocemusque in disputationem.

[R.b.3] Duas praecipue conclusiones in illa priori relectione stabilivimus et nisi fallor abunde id monstravimus. Prima illa fuit quod penes solos apostolos fuerit auctoritas condendae sacrae scripturae quantum attinet ad novum testamentum. Et altera quod auctoritas sacrae scripturae quoad ${ }^{151}$ utrumque testamentum est tanta ${ }^{152}$. Immo vero est eadem quae est auctoritas Dei, et quae a Deo licet per impossibile vel tota ecclesia vel ipsi resurgentes apostoli vel angeli de caelo quod inquit Paulus etsi fas est dicere, ipse Deus oppositum diceret, non esset credendum, immo persistendum potius in priori verbis sacrae scripturae. Alterum punctum propositum tunc fuit circa numerum librorum canonis, de quo praesertim in praesentiarum dicendum nobis est. Et si tempus reliquum fuerit $3 \mathrm{um}$. membrum, nempe de sensibus sacrae scripturae utcumque attingemus. Sin autem forte modo tantam molestiam ferre possitis, aliam de illo relectionem accumulabimus ut sit scriptus et in tergo nondum finitus Orestes.

[R.b.4] Et quia relectionem hanc $2^{\circ}$ sententiarum quem anno elapso interpretati sumus accomodare tenemur, versabitur ${ }^{153}$ nostra disputatio circa 12am. sequentesque distinctiones ${ }^{154}$ eiusdem libri ubi magister exponit primum caput Genesis eritque tota posita in expositione eiusdem prothematis superioris relectionis quod est illud Apoc. $5^{\circ}$. Vidi in dextera sedentis super thronum librum scriptum intus et foris. Primum ormnium dicturis nobis de catalogo librorum canonicorum interpretandum quidem esset nomen libri canonici nisi quod supra in fronte prioris relectionis id iam praestitimus. Igitur inde censemus disputationem nostram congrue profecturam si statim in ipso vestibulo fundamenta faciamus quibus explorandi sunt libri canonici.

[R.b.5] Et sic prima fundamentalis conclusio. Libri canonici non aliter quam auctoritate ecclesiae recipiuntur ex cuius perinde sola auctoritate aut

\footnotetext{
${ }^{149}$ Ms. mihi.

${ }^{150}$ Ms. Rrem.

${ }^{151}$ Ms. quod.

${ }^{152}$ Ms. santa.

${ }^{153}$ Ms. versavitur.

${ }^{154}$ Ms. distintiones.
} 
auctoritate summi pontificis efficax sumitur argumentum ad comprobandum librum quendam canonicum esse necne. Ratio est in promptu. Nam canonem divinarum scripturarum constituere nihil aliud est quam proponere fidelibus ea quae sunt revelata ut credantur. Sed hoc pertinet ad solam ecclesiam. Ergo. Maior perspicua est et declaratur minor. Duo requiruntur ad actum fidei ut docet s. Thomas $2^{\text {a }}$. 2ae. q. 6. ar. $1^{\mathrm{o}}$, nempe habitus in intellectu inclinans ad assensum et $2^{\circ}$ ut credibilia nobis proponantur. Si enim non proponerentur mihi credibilia, non possem credere. Et utrumque est opus Dei qui est auctor fidei iuxta illud Eph. $2^{\circ}$. Gratia estis salvati per fidem; donum enim Dei est. Sed tunc ista duo differenter donantur a Deo. Nam habitus fidei inmediate infunditur a Deo in baptismate, sed quantum ad $2 \mathrm{um}$. non inmediate proponit ómnibus credibilia, sed hoc facit per ecclesiam iuxta illud Pauli Roma. 10., quomodo credent ei quem non audierunt, quomodo autem audient sine praedicante? Cum ergo ad ecclesiam pertineat proponere credibilia, ad ipsam perinde pertinet discernere ${ }^{155}$ qui $^{156}$ libri sint canonici. Et confirmatur haec ratio, quia non potuit nobis alia via provideri commodiori ut cognosceremus scripturam revelatam quam auctoritate ecclesiae.

[R.b.6] Nam ut auctor est Augustinus 25. librum contra Faustum, etsi libri manu propria ipsius Iesu Christi vel apostolorum conscripti usque adhuc modo tempora incolumes perdurasent, non pos- [fol. 255r] semus credere eos ese illorum libros nisi quispiam qui divinam haberet auctoritatem id nobis modo affirmaret, nisi quis dicat cum quibusdam haereticis quod singuli deberemus expectare de hoc particulares revelationes. Sed certe hoc est contra divinam providentiam, quae iam omnia sufficienter revelavit. Hanc veritatem tradit imprimis Nicholaus papa in capitulo si romanorum 19. dist. Eandem voluit nos docere Augustinus contra epistolam Manichaei capitulo $5^{\circ}$. Evangelio non crederem nisi me ecclesiae catholicae conmoveret auctoritas, id est nisi me edoceret hoc esse evangelium. Unde contra Faustum libro $11^{\circ}$. capitulo 28. 32. pro indubitato habet non aliam esse viam ad explorandum sacram scripturam nisi solum auctoritatem ecclesiae, non istius solum quae modo est sed quae ab ipso Christo per apostolos inquit succedentibus sibimetipsis usque adhuc tempora propagata dilatatur. Et libro 13. capitulo 4. Quomodo, inquit, dabit Faustus scripturis suis auctoritatem quam per ecclesiam Christi ab ipsis apostolis constitutas non acceperit? Et Irenaeus libro $3^{\circ}$ adversus valentinianos capitulo $3^{\circ}$. idem docet, scilicet quod apostoli tradiderunt episcopis, et alii aliis successoribus usque ad nos illa quae sunt tanquam ex fide tenenda. Et Tertulianus inde praescriptionibus haereticorum idem docet. Ait enim quod

\footnotetext{
${ }^{155}$ Ms. descernere.

${ }^{156}$ Ms. quod.
} 
Christus revelaverit apostolis non aliter probari debet nisi per easdem ecclesias quas ipsi apostoli condiderunt.

[R.b.7] At dubium est. Quando dicimus ecclesiam habere auctoritatem recipiendi libros in canonicos quam videlicet ecclesiam intelligimus, utrum totam ecclesiam a tempore apostolorum includendo ipsos, an istam etiam quae modo est sine apostolis. Ita enim distinximus de ecclesia in superiori relectone. Videntur auctoritates istorum sanctorum innuere quod sola ecclesia primo modo inclusis apostolis habeat auctoritatem decernendi quis liber sit canonicus. Nam dicunt quod hoc habemus ab apostolis per ecclesiarum successionem. Arguitur adhuc sic. In prima relectione nos comprobavimus totam ecclesiam sine apostolis non posse condere sacram scripturam, nec posse decemere propositionem aliquam tanquam de fide nisi [quatenus] colligitur ex sacra scriptura. Haec autem propositio: Hoc est evangelium Matthaei vel haec est epistola Pauli et similes, non inferuntur ex alia sacra scriptura sed inmediate asseruntur ab ecclesia. Ergo hoc non potest ecclesia diffinire sine apostolis. Et confirmatur, quia alias ecclesia quae nunc est reciperet aliquam inmediatam revelationem sicuti apostoli, et sic posset condere eadem ratione sanctam scripturam.

[R.b.8] His tamen non obstantibus respondemus quod ad ecclesiam quae nunc est et ad quamcumque est suo tempore etiam sine apostolis pertinet determinare quis liber sit canonicus. Et ratio est quia alias non esset nobis satis provisum a Deo ad habendum hanc certitudinem. Non enim sum ego certus quod hoc evangelium quod est ${ }^{157}$ Matthaei est nobis traditum ab apostolis per successionem ecclesiarum nisi quia ista ecclesia quae modo est mihi asserit. Alias quomodo scirem quod hoc tradidit ecclesia ${ }^{158}$ quae fuit tempore Hieronyrni. Et ideo Augustinus in illis verbis citatis: Evangelio non crederem nisi me Ecclesiae moveret auctoritas, de ecclesia quae erat suo tempore loquebatur. Sed sit $2^{\mathrm{a}}$ propositio haec notanda, quod ecclesia non potest determinare hunc aut illum librum esse canonicum per inmediatam revelationem, sicut Ioannes asseruit: In principio erat Verbum, sed hoc colligit vel ex conciliis precedentibus vel ex dictis episcoporum praeteritorum vel viva voce ex historiisve vel aliis coniecturis. Sed non potest errare in tale collectione. [fol. 255v] Itaque quemadmodum si ecclesia vellet determinare unam propositionem esse de fide non eliciendo illam ex sacra scriptura erraret (sed tamen non permittetur sic facere), ita si vellet determinare hunc librum esse canonicum non eliciendo ex historiis patrum vel aliis coniecturis, sed expectando novam revelationem, erraret.

\footnotetext{
${ }^{157}$ Ms. esse; es decir, en vez de quod est.

${ }^{158}$ Ms. ecclesiam.
} 
[R.b.9] Sed tamen non permittetur id facere, hoc puto satis comprobant rationes supra citatae. Nam Augustinus, Tertullianus, Irenaeus et verisimiliter omnes dicunt quod ecclesia hoc habet ab apostolis per successionem ecclesiarum. Item, quia alias non esset satis provisum ecclesiae cum esset expectanda nova revelatio. Unde semper est verum quod ecclesia non potest condere sacram scripturam, quia ista: Hoc evangelium est Matthaei, non est sacra scriptura, sed est assertio quod alia est sacra scriptura nec est inmediate revelata sed mediate per apostolos et successores eorum. Adde quod etiam papa potest determinare librum quempiam esse canonicum, maxime secundum s. Thoman et eos qui dicunt posse determinare articulum fidei, sed eliciendo, ut diximus, ex antiquis.

[R.b.10] $2^{\mathrm{a}}$ principalis et fundamentalis conclusio sit haec: Ecclesia non statim in eius exordio nec simul recipit universos libros canonicos sed successu temporum, nunc alios, postea vero alios. Nam solum volo dicere quod non tota simul fuit scripta, nam hoc est clarum. Sed post ipsa apostolorum aliquando ecclesia dubitavit de aliquibus libris quos postea recepit. Hoc patet ex ipsis conciliis et doctoribus antiquis. Nam in concilio laodicaeno canone 59 recipiuntur omnino libri veteris testamenti exceptis illis sex quos excipit Hieronymus in prologo galeato, scilicet Tobia, Iudith ${ }^{159}$, libro Sapientiae, Ecclesiastico et libro Machabaeorum, qui tamen omnes postea sunt recepti in concilio carthaginensi. Et ex novo testamento, illic non legitur Apocalypsis Ioannis, ergo postea recipitur in eodem concilo carthaginensi. Et de epistola Hebraeorum dicit Hieronymus in epistola ad Evagrium et in expositione super Esaia c. 6. et 8. quod adhuc suo tempore universalis ecclesia latinorum non receperat illam quae tamen iam modo est recepta concilio carthaginensi et florentino. Et idem Hieronymus in de viris illustribus dicit epistolam Iacobi paulatim tempore praecedente obtinuisse auctoritatem. Unde Augustinus $2^{\circ}$. De doctrina christiana c. 8. tenebit, inquit, scripturarum indagator hunc modum in scriptis canonicis, ut eas quae ab omnibus ecclesiis catholicis recipiuntur praeponat eis quas quidam non accipiunt; in eis vero quae non accipiuntur ab omnibus praeponat eas quas plures gravioresque accipiunt eis quas pauciores minorisque auctoritatis ecclesiae tenent. Ubi perspicue docet quod successive et per temporum incrementa recepti sunt libri canonici.

[R.b.11] Sed dubium facit ista conclusio cum quia sequitur quod Deus non statim sufficienter providit ecclesiae, postquam mansit per aliquot tempus sine certitudine librorum, tum etiam quia videtur pugnare cum his quae supra diximus, nam diximus ecclesiam non posse recipere librum canonicum nisi colligendo ex antiqua successione ecclesiarum. Si ergo ab apostolis per

\footnotetext{
${ }^{159}$ Ms. Iudich.
} 
continuam successionem recipit libros canonicos, nunquam non fuit certa de hoc. Respondemus ad primum quod in his quae sunt necesarii ad fidem statim ecclesia fuit instructa, at non erat adeo necessarium scire an Tobias [fol. 256r] v.g. esset sacra scriptura. In illis ergo ecclesia paulatim profecit sicut caput eius Christus qui non dedignatus est proficere scientia et aetate, unde de ecclesia etiam canunt filiae Hierusalem Canticorum 6. Quae est ista quae progreditur quasi aurora consurgens, id est maiora in aurora, maiora quam lucis incrementa recipiens. Ad aliud dicendum quod non erat necesse continuo haberi certitudinem omnium librorum licet haberetur per successionem, nam aliquando ecclesia non erat circa hoc sollicita vel quia erat aliis intenta, sed postea patres de hoc solliciti ex antiquis historiis vel traditionibus vel viva voce colligebant alium vel alium librum canonicum.

[R.b.12] His factis fundamentis subsequitur principalis quaestio in qua tota disputatio nostra versabitur, nempe utrum omnes libri quae in bibliis circumferuntur nostris sint utique adeo canonici ut illud negare sit haereticum. Et ne opus sit saepe eos repetere universos quotquot in bibliis continentur, oculis vobis iniiciam omnes simul libri ut ac novi testamenti sunt numero 74., nam libri veteris testamenti sunt Genesis, Exodus, Leviticus, Numeri, Deuteromonium, quos vocant Pentateuchum, id est volumen 5. librorum. Mox sequuntur Iosue, Iudicum, Ruth; 4or. Regum, 2. Paralipomenon; 4or. Esdrae, Tobias, Iudith, Esther ${ }^{160}$; deinde liber Psalmorum et 5. libri que dicuntur Salomonis ut puta Proverbia, Ecclesiastes, Cantica canticorum, Sapientia et Ecclesiasticus; praeterea 4or. prophetae maiores ut Esaias, Hierernias, Ezechiel, Daniel adiumento Baruch, et 12. minores, scilicet Oseas, Ioel, Amos, Abdias, lonas, Michaeas, Nahum ${ }^{161}$, Abacuch, Sophonias, Aggaeus, Zacharias, Malachias; ac demum 2. Machabaei complent numerum 47. librorum. Libri novi testamenti sunt hi 4or. evangelistas, Acta apostolorum, 14. epistolas Pauli, scilicet una ad Roma., 2ae. Cor., 1. Gala., 1. Ephae. 1. Phili., 1. Colosse., 2. Thesalo., 2. Timo., 1. Titum, 1. Phile., et 1. Hebrae.; deinde 1. Iacobi, 2. Petri, 3. Ioannis, 1. Iudae cum Apocapylsi complent 27. libros, quo fit ut omnes utriusque testamenti colligantur ad numerum 74 .

[R.b.13] Totum istum canonem ab ipso statim exordio nascentis ecclesiae haeretici homines semper conati sunt evertere et prorsus stirpare, nam cerdoniani ${ }^{162}$ primum, deinde sevriani ${ }^{163}$ ut refert Augustinus libro de haeresibus capitulo 21. et 24 . Totum vetus testamentum negabant quamquam sint qui hanc haeresim

\footnotetext{
${ }^{160}$ Ms. Hester.

${ }^{161}$ Ms. Naum.

${ }^{162}$ Ms. cerdeniani.

${ }^{163}$ Ms. securiani.
} 
in antiquiorem Carpochratem revolvant, quam quidem haeresim Manichaeus postea nobilitavit dicens vetus testamentum a malo Deo fuisse. Adversus quem errorem Augustininus scripsit libros contra Faustum Manichaeum et Tibonem auctore Irenaeo libro $1^{\circ}$. adversus valentinianos c. 26. ex novo testamento solum Matthaeum recipiebat et ornnes epistolas Pauli reiiciebat; Faustus vero nec Matthaeum in universum recipiebat, et universi vel alii item haeretici reliquas epistolas aliorum apostolorum excludebant a sacro canone, ut est videre de Valentino, Marcione et ceteris haereticis apud Irenaeum, Tertulianum et Augustinum in illis libris quos adversus haereticos conscripserunt. Atvero non [fol. 256v] est nobis corde de universis libris disputare, nam contendere cum illis haereticis a quibus iam Deo actore liberata est ecclesia, labor erat non tam utilis quam prolixus, ac subinde fastidiosus, sed solum duximus operae praecium adducere aliqua generalia fundamenta ad explorandum libros canonicos. Quantum possumus ex auctoribus colligere disputabimus nonnihil de illis solum de quibus inter sanctos patres ecclesia etiam iam adulta dubitatum fuit, immo de quibus modo inter aliquos nonnulla est dubitatio.

[R.b.14] Et primum, quantum attinet ad vetus testamentum ut certa ab incertis separemus, illos 47. libros memoratos in 3. partes dividamus. Sunt enim ex illis 3 . qui sine controversia sunt apocryphi et 6 . de quibus aliquando fuit dubitatum, et ceteri 38. de quibus nisi inter haereticos nullum fuit dubium quominus essent canonici, tres primi sunt: tertius et quartus Esdrae et libellus qui inscribitur Baruch. 2i. generis sunt Tobias, Iudith, liber Sapientiae et Eclesiasticus et 2. ibri Machabaeorum. De aliis 38. connumeratis nulla fuit unquam dubitatio. Et quo ista perspicua fiant sumamus ex Origene. Et ex Hieronymo in prologo galateo super librum Regum ubi docet 22. Libros canonicos esse apud hebraeos iuxta numerum 22. litterarum quibus ipsi utuntur, et sub nomine 22. connumerat omnes illos 38., quos nos numeravimus exceptis illis quae primi et secundi generis. Nam librum Ruth comprehenditur in libro Iudith et ex 4. Regum facit 2. solum et ambos Paral. apellat unum, sicut ambos Esdrae, scilicet primum et $2 \mathrm{um}$. vocat unum, nam $3 \mathrm{um}$. et $4 \mathrm{um}$. et Baruch silentio praeterit utpote Apocalyp., et 12. prophetas minores comprehendit sub uno libro et sic quos non distinguimus in 38. iuxta divisionem vulgatam, ipse iuxta partitionem hebraeorum comprehendit sub 22. Et subiungit igitur Sapientiam, quae vulgo Salomonis inscribitur et Iesu filii Syrach liber quem nos vocamus Ecclesiasticum. Et Iudith et Tobias et Pastor, non sunt in canone. Machabaeorum primum librum hebraicum ${ }^{164}$ reperi. 2 us graecus est haec Hieronymus ex quibus possumus colligere illam tripartitam divisionem quam annotavimus.

${ }^{164}$ Ms. ebraicum. 
[R.b.15] Sed priusquam ad rem proprius accedamus dubium suboritur circa partitionem Hieronymi. Partitur namque vetus testamentum in 3., scilicet in legem, prophetas et libros quos vocant hagiographos ${ }^{165}$, id est libros sancte conscriptos seu libros sanctos. In primo ordine ponit solum Pentatheucum et in $2^{\circ}$. collocat Iosue et librum Iudicum cum Ruth et librum Regum cum ceteris quos nos vocamus prophetas. Et in $3^{\circ}$. ordine constituit Iob et Psalterium et librum Salomonis cum Daniel, et Paralipomen, et Esdra, et Esther. Dubium, inquam, est triplex. Primum, quod libri ipsi legales sunt pariter prophetici, nam Moyses fuit eximius prophetarum. Quomodo ergo lex distinguitur a prophetis? $2 \mathrm{um}$. dubium est quod inter prophetas connumeratur Iosue et liber Iudicum et Ruth et libri regum, qui tamen sunt omnes historiales quod si quis dixerit multa prophetica continere, arguitur contra quia etiam Iob multa prophetica continet, quem tamen non collocant nisi inter hagiographa. $3 \mathrm{um}$ maius dubium est quare Iob et David et Danielem ex numero prophetarum exceperit cum sint prophetae, immo David antonomastice nomen prophetae obtineat.

[R.b.16] Ad primum respondemus [fol. 257r] quod licet Moyses ${ }^{166}$ prophetavit et in Pentatheuco multa et sint prophetica, tamen propter dignitatem legis et mandatorum Dei quae illic conscribuntur a principaliori illi libri praenominatur lex, quare in evangelio distincte citantur lex et prophetae. Ad $2 u m$. Dicendum quod licet illi libri multas historias describant, tamen sunt duo ${ }^{167}$ prophetici, nam etsi Esaias et Hieremias prophetae sunt, tamen continent multas historias, unde Hieronymus in epistola ad Paulinum. Veniam, inquit, ad Iesum ${ }^{168}$ Nave, qui typus Domini non solum gestis, sed etiam nomine est, et infra iudicum libri quot ${ }^{169}$ principes populi tot figurae sunt. Ruth moabitis Isaiae implet vaticinium Samuel in Heli mortuo et in occiso Saul veterem legem abolitam monstrat; porro in Sadoc atque David novi sacerdotii novique imperii sacramenta testantur; et de reliquis libris Regum testatur si historiam respicias; verba simplicia sunt si in litteris sensum latentem inspexeris ecclesiae paucitas et haereticorum vella contra ecclesiam narrantem.

[R.b.17] Sed nunc restat ad 3um. dubium. Nam et illic dicit de Job quod resurreccionem corporum sic prophetat ut nullus de ea vel manifestius vel cautius scripserit. Quomodo ergo Iob et maxime Daniel et David non collocat

${ }^{165}$ Ms. agiographos.

${ }^{166}$ Ms. Moses. Es cierto que unas veces se escribe así en la vulgata; pero se seguirá aquí la costumbre de transcribir siempre Moyses.

\footnotetext{
${ }^{167}$ Ms. duae.

${ }^{168}$ Ms. Iesu.

${ }^{169}$ Ms. quod.
} 
in ordine prophetarum? Ad hoc dupliciter respondetur. Uno modo quod Hieronymus illic non possuit propriam sententiam et veram sed retulit quod esset in opinione hebraeorum ut ipse in Apologia adversus Ruffinum libro $2^{\circ}$. insinuat, dicens: De Daniele autem breviter respondebo me non negasse eum prophetam quem statim in fronte prologi prophetam professus sum, sed quod hebraei dicebant voluisse monstrare et Valentinus ille constantinopolitanus episcopus in prologo super Psalterium dicit quod licet hebraei ante adventum Domini non dubitassent David esse prophetam, tamen postea cognoscentes quod tam aperte prophetasse de Christo malitia ducti sunt ut eum excluderent a prophetis. $2^{\circ}$. modo potest responden et forte verisimilius quod hebraei non collocabant in ordine prophetarum omnes qui propheticam cognitionem habebant, sed eos solum qui ex officio missi fuerant a Deo ad annuntiandum aliquid vel regi vel populo, sicut Moses missus est pharaoni et Josue missus est ad introducendum populum, et ita de ceteris prophetis. Job vera et David et Daniel licet cognitionem habuerunt propheticam, non tamen missi sunt ex officio ad praedicandum. Et certe David saltem quod singulariter a ceteris prohetis separetur, videtur comprobare testimonio Christi Luc. ultimo qui distinguit inter legem prophetas et psalmos, forte propter dignitatem divinarum laudum quae sunt in psalmis. Haec de distinctione Hieronymi.

[R.b.18] Aliter Augustinus partitur vetus testamentum $2^{\circ}$. de doctrina christiana c. 8 . De qua statim igitur ad divisionem illam quam fecimus revertentes statuimus hic primam conclusionem. 3us. et 4us. Esdrae et libellus qui praenotatum Baruch citra controversiam apochryphi. Hanc conclusionem satis comprobat quod ecclesia acterius ${ }^{170}$ non recipit illos in canonem ut est videre in omnibus conciliis et decretis pontificum quae infra recitabimus et iam diximus in primo fundamento sola auctoritate ecclesiae habere libros canonicos, et quamquam in bibliis circumferantur, illic tempore notatur non esse de canone, ut est videre in prologo super 3 um. Esdrae et super Baruch. Illi non sunt prologi Hieronymi sed sunt annotationes antiquae. Verumtamen est Hieronymus in prologo super totum Esdram [fol. 257v] vocat 3um. et 4um. apocriphos, somnia. Et in prologo super Hieremiam dicit quod librum Baruch notarii Hieremiae quia apud hebraeos nec legitur nec habetur praetermisit. Et certe 3. et 4. Esdrae manifestum est non esse de Esdra editos, non praeterquam quod phrasis ipsa dicitur a prioribus libris. Argumentum etiam est manifestum quod 3 us. nihil aliud continet quam frustra ex ilibris Regum et Paralipo., immo per multa ex ipso priori libro Esdrae decepit. Sed tamen propter antiquitatem illorum manent in bibliis.

\footnotetext{
${ }^{170}$ Es posible que se quisiera decir anterius (anteriormente); pero creo que se refiere a que no hay constancia en actas y, de ahí, acterius.
} 
[R.b.19] Verum est quod Baruch ut habetur in illa praenotatione in capite eiusdem libri, licet non habeatur in hebraeo canone, est tamen in vulgata editione, et ideo aliquantulum est maioris auctoritatis quam ultimi libri Esdrae eo vel maxime quia multa clarissime de adventu Christi et redemptione nostra probantur illic sub nomine liberationis babilonicae, unde Cyprianus, Ambrosius et ceteri patres saepe eius testimoniis utuntur. Verumtamen hic vos admonere opus est propter Isidorum libr. 6. ethimologiarum capitulo 2. 3. et 4um. Esdrae non haberi apud hebraeos sed apud apocryphos esse deputatos, ubi videtur 2 um. etiam inter apocryphos nominare quod est Nehemiae ${ }^{171}$. Sed tamen notandum quod Isidorus non intendit excipere a canone illum 2 um. librum quem vocamus Nehemiae, sed illum comprehendit in $1^{\circ}$. libro Esdrae, et expresse enim dicit quod sermones Nehemiae pariter continentur in textu Esdrae iuxta morem hebraeorum qui, ut Hieronymus dicit in prologo super 1um. Esdrae. Primum Esdrae et sermones Nehemiae in unum librum coartant et haec est ratio qua librum Nehemiae intitulamus Esdrae, et quod non disinguimus in 3um. et 4 . iuxta partitionem graecorum et latinorum, ipse distribuit in 3., scilicet 2 um. Et 3 um. et 4 um., quos bene vocat apocryphos. De illo libello Pastoris cuius meminit Hieronymus in dicto prologo galeato, non facimus hic incutionem, quia usque adeo certum est esse apocryphum ut in bibliis etiam non habeatur. Meminit illius Cyprianus in expositione symboli qui inter opera Hieronymi Ruffini nomine praenotatur: Meminit, inquam, illius inter apocriphos novi testamenti tanquam pastoris cuiusdam vel Hermatis, et idem censet de illo Eusebius libro $3^{\circ}$. c. 25.

[R.b.20] $2^{\text {a }}$ conclusio. De illis sex libris $2^{\circ}$. ordine notatis, scilicet Tobia, Iudith, lib. Sapientiae, Ecclesistico et 2. Machabaeorum, diu fuit etiam in ecclesia catholica dubitatum an essent canonici, id est divinam auctoritatem haberent. Tametsi haberentur in magna auctoritate, oppositum huius videtur sentire modernus Driedo li. $1^{\circ}$. c. $3^{\circ}$. Dicit enim Hieronymum in prologo galeato non velle excipere illos libros a canone ecclesiae catholicae, sed quod solum intendit subputare canonem secundum hebraeos. Sed revera puto nec ecclesiam eos recepisse tanquam canonicos, saltem ita fuisse in opinione Hieronymi. Et probatur primo quia alias Hieronymus nos admonuisset de hoc, scilicet quod ecclesia habebat tanquam canonicos, et tamen hoc non dicit sed absolute infert quod illi libri non sunt in canone.

[R.b.21] Sed $2^{\circ}$. quo tota ista nostra solutio perspicatior fiat arguitur sic, quod ecclesia aliquo modo dubitavit illum canonem quem illis conmmemorat Hieronymus. Prius ecclesia recipit ab hebraeis. Primus enim apud quem reperitur est Iosephus adversus Apionem li. $1^{\circ}$., ubi dicit infiniti libri non sunt

${ }^{171}$ Ms. Neemiae. 
apud nos, sed solum duo et viginti libri. Deinde ecclesia graecorum ita habuit. Primus autem Dionysius Areopagita c. $3^{\circ}$. ecclesiae hierarchia canonem refert ecclesiasticorum librorum, non quidem de nomine [fol. 258r] eos nuncupans, sed singulorum materias insinuans. Ait enim omnes sacrae scripturae textus aut rerum substantiam ac distinctionem a Deo conditam praedicant quoad Genesim, ut legale sacerdotium, quoad Exo. et Levi., et ita discurrit per singulos usque ad Apocalypsim, quam vocant arcanam et mysticam revelationem dilecti discipuli. Sed loquamur ut solet obscurissime mox Origenis $^{172}$ in expositione primi psalmi referente Eusebio li. 6. c. 15. Non est ignorandum, inquit, 22. esse libros in canone ut testatur; sicut hebraei tradunt secundum numerum elementorum quae apud ipsos habentur. Et connumerat eosdem quod Hieronymus eisdem 6. exceptis. Et Damascenus etiam graecus li. 4. c. 15. eandem refert sententiam. Et ideo ecclesia graecorum statim in suo exordio non est alios libros persecutata vereris testamenti quam quos tunc habebant hebraei ut est videre in concilio laodicaeno c. 59. ubi idem libri recensentur quos refert Hieronymus.

[R.b.22] Quod adhuc confirrnatur auctoritate antiquissimi Milletonis episcopi sardensis apud Eusebium li. 4. c. 26. cuius verba sunt. Ut suas perrexise, me usque ad orientis locum ubi praedicationis nostrae cepit exordium, et ubi gesta sunt omnia quae leguntur scripta, ibique diligenter explorasse de omnibus quae essent veteris testamenti volumina, ubi igitur quae cum omni investigatione comperi haec sunt: Moysi quinque libri, et refert omnes exceptis eisdem quos excepit Hieronymus. Et refert: Ecce quomodo graeci non habebant alios libros tanquam canonicos a quibus primi etiam latini eos receperant. Unde Ciprianus in dicta expositione symboli vel Ruffinus si fuit auctor eosdem omnino libros refert et subiunxit: Sciendum tamen est quod etiam alii libri sunt qui non canonici, sed ecclesiastici a maioribus appellati sunt, ut sunt illi 6. quos nos cormmemoravimus, scilicet Tobias, Iudith, Sapientia, Ecclesiasticus et liber Macabaeorum. Et eadem etiam sententia Hieronyrni, unde in prologo super Proverbia expresse dicit sicut ergo Iudith et Tobiam et Macchabeorum libros legit ecclesia, sed eos inter canonicas scripturas non recipit, sic et haec duo volumina Sapientiae et Ecclesiastici legit ad aedificationem plebis, non ad auctoritatem ecclesiasticorum dogmatum confirmandam. Ubi expresse dicit Hieroymus quod ecclesia non recipiebat tunc illos 6. libros in canonicos.

[R.b.23] Et miror diligentissimum Driedo non advertisse ad ista verba, nam quanquam li. $1^{\circ}$. c. 4 . ad 7. difficultatem respondeat ad verba Cypriani, scilicet quod ecclesia legit: non, ad auctoritatem fidei confirmandam ex illis,

${ }^{172}$ Ms. Origenes. 
respondet, inquam, Cyprianum solum intelligere non valere ad confirmandam fidem adversus iudaeos, sed solum inter catholicos, non tamen respondent ad verba Hieronyrni, scilicet quod ecclesia non recipit istos libros dictos in canonicos, nec ad verba Cypriani, scilicet quod a maioribus non canonici sed ecclesiastici dicuntur, et ideo credo quod Cyprianus et Hieronymus sicut omnes graeci intelligunt quod ecclesia non habebat tunc pro canonicis. Et divus Thomas super Dionysium 4. c. de Dionysio non ubi Dionysius citat librum scripturae sub nomine Philonis velut alius textus habetur, scilicet quídam dicunt: Dicit, inquam, s. Thomas unde colligitur quod liber Sapientiae nondum erat tunc inter catholicas scripturas, [fol. 258v] ubi insinuat quod iam certo est inter canonicas scripturas, licet tunc non fuisse. Et idem est de aliis quinque.

[R.b.24] Quid si quis arguat quod Hieronymus in prologo super Iudith et Tobiam dicit illos libros esse inter hagiographa, et tamen in prologo galeato hagiographa connumeravit in canone. Item in prologo Iudith dicit illum librum synodus nicaena in numero sanctarum scripturarum legitur computasse. Ergo videtur quod Hieronymus iam haberet illos pro canonicos. Respondemus ad lum. quod cum Hieronymus in prologo galeato dicat secundum hebraeos illos libros esse extra canonem, et idem repetat in prologo Tobiae, necesse est dicere quod quando dicit illic esse hagiographos vel quod est mendum, scilicet hagiographos pro apocryphos vel quod accepit hagiographa, non sicut in prologo galeato, sed pro libris sanctorum extra canonem, sicut possemus librum Hieronymi vel Augustini vacare hagiographa. Ad 2 um dicimus quod Hieronymus non dicit nec insinuat se legisse in actis concilii illud decretum, sed alibi in alio auctore, et ideo hoc sub opinione relinquit, vel dicimus quod solum forte intelligit synodum nicaenam recepisse illos libros, non pro canonicis sed pro ecclesiasticis, ut dicit ipse in verbis allegatis super Proverbia, et etiam Cyprianus.

[R.b.25] 3a. propositio est. His non obstantibus iam illi sex libri cum ceteris 18, omnes inquam 44. veteris testamenti sunt canonici. Oppositum dicunt nonnulli, ut Nicholaus de Lyra ${ }^{173}$ super Tobiam et super Esdram. Et noster divus Antoninus 3. p. to. 18. c. 62. Et dominus Abulensis in prologo super Matthaeum q. $2^{\text {a }}$. et 4 . Ait enim quod non recipiuntur tanquam efficaces ad testimonium fidei nec tanquam de canone. Et Antoninus dicit quod recipiuntur tanquam libri aliorum sanctorum, scilicet Augustini vel Hieronymi. Sed tamen probatur nostra propositio. Nam dictum est in primo fundamento sola auctoritate ecclesiae et pontificum hoc esse comprobandum, sed ecclesia iam recepit et conmemorat inter canonicos. Primo in concilio carthaginensi $3^{\circ}$.

${ }^{173}$ Ms. Lira. 
Cum subscripsit Augustinus c. 47. sunt omnes illi, sunt omnes illi comnumerati tanquam canonici, unde Augustinus $2^{\circ}$. de doctrina christiana c. 8. Eosdem recensuit dicens circa 44. numero, sed ut verum fatear inter illos dicit alias aliis praeferendos secundum quod a pluribus aut gravioribus ecclesiis sunt recepti. Nam concilium carthaginense non fuit nisi provinciale, sed est tamen iam auctoritas Innocentii in epistola ad Exuperium archiepiscopum toletanum c. 7., ubi omnes dicti libri tanquam canonici numerantur.

[R.b.26] Idem est decretum Gelasii papae ubi cum 70. episcopis retulit eosdem 44. libros in canone et, ut supra diximus, papa in hoc errare non potest. Et tandem est expressum concilium florentinum ubi idem cathalogus traditur graecis et universali ecclesiae. Unum cavillum et subterfugium posset hic allegari, scilicet quod quamquam ecclesia illos referat, non tamen recipit pro canonicis, quia non determinavit illud tanquam de fide sicut iam modo dicebamus. Et forte Hieronymus ita opinatus est nicaenam synodum recepisse illos libros, non tanquam canonicos sed tanquam ecclesiasticos. Respondetur ad hoc quicquid sit de opinione Hieronymi vel de concilio nicaeno in qua non circumfertur illud decretum, [fol. 259r], iam non possumus negare ese canonicos, nam per hoc quod ecclesia ubi fit mentia de libris canonicis dictas 6. libros promiscue inter alias connumerat sine aliqua nota distinctionis, plane intelligit omnes esse canonicos. Alias eodem modo posset dubitari de evangelio et de ceteris libris. Et certe si sub eodem tenore qua sunt in concilio florentino Hieronymus vidisset eos in concilio nicaeno vel nos vidissemus. Nec ipse nec nos dubitassemus esse canonicos.

[R.b.27] Et confirmatur quia promiscue cantantur in ecclesia illi libri inter alias canonicos, nempe sicut in quadragessima legitur Genesis, ita in mense augusto legitur liber Sapientiae et mense septembri Iob et octobri Machabaeorum. Quod comprobatur decreto Gelasii c. sancta romana d. 15. Ex dicta conclusione sequitur nullum esse argumentum. Origenes, Cyprianus, Hieronymus et ceteri non habuerunt illos libros pro canonicos. Ergo non sunt canon ci. Nam ut diximus in $2^{\circ}$. fundamento, ecclesia succesius fuit edocta libros canonicos. Et ipse Hieronymus confitetur epistolam Iacobi praecedente tempore obtinuisse auctoritatem, et idem sentit de libro ${ }^{174}$ Sapientiae, ut iam citatum est. Et in hoc ut bona venia dixerim gravissimorum doctorum decepti sunt: doctissimus Nicholaus de Lyra et dominus Antoninus, et dominus Abulensis, inferentes quod quia Hieronymus non habuit pro canonicis, non sunt habendi pro talibus, et ita dicit Antoninus quod non habent auctoritatem nisi ut libri sanctorum, scilicet ut Hieronymi et Augustini et aliorum id genus.

${ }^{174}$ Ms. libros. 
[R.b.28] $4^{\text {a }}$ propositio sit. In illo articulo temporum quo floruerunt Hieronymus et Augustinus, ceperunt dicti libri iam pro canonicis haberi, scilicet post annum $400 \mathrm{~m}$. redemptionis nostrae. Tunc enim fuit Innocentius primus tempore Hieronymi cuius decretum quod iam supra citavimus Hieronymum vidisse. In eodem centenario fuit Gelasius. Tunc item fuit concilium carthaginense 3um. et Augustinus qui non dubitat esse eos canonicos, unde praeter locum iam citatum $2^{\circ}$ de doctrina christiana c. 8. et li. $1^{\mathrm{o}}$ de praedestinatione sanctorum c. 14. dicit librum Sapientiae omnibus tractatoribus anteponendus quomodo cum sibi anteposuerunt etiam temporibus proximi apostolorum qui eum testem adhibentes nihil se adhibere nisi divinum testimonium crediderunt, et 14. de civitate Dei c. 6. dicit libros ${ }^{175}$ Machabaeorum non iudaeos sed ecclesia ${ }^{176} 83$ pro canomcis habet propter quorundam martyrum passiones qui ante adventum Christi usque ad mortem pro lege Dei certaverunt. Et praeter omnes clarissima sententia Isidori doctoris gravissimi fere illius temporis li. 6. ethimologiarum c. 10. postquam retulit catalogum veteris testamenti eo modo quo refert Hieronymus in prologo galeato, subiunxit: Quartus est apud nos ordo veteris testamenti eorum librorum quos hebraei in suum canonem non recipientes inter apocrypha supputant, quos christiana ecclesia inter divinos honorat et praedicat libros. Non ergo decet dubitare quominus omnes illi libri sint iam in canonem relati.

[R.b.29] Sed est argumentum contra istam determinationem. Nam ut Augustinus saepe repetit catalogum veteris testamenti recipimus christiani ex traditione hebraeorum. Unde super Ps. 58. dicitur super illos versu ne occidas eos neque obliviscantur populi mei, seu legis tuae, ut ipse legit; sed disperge illos in virtute tua, dicit in quantum quod in utilitatem ecclesiae christianae factum est ut [fol. 259v] iudaei quantumcumque debellati contra Romam non occiderentur sed superstites dispergerentur per orbem ut essent testimonio legis et prophetarum ne christianus quis posset negare illos esse libros prophetarum veteris legis cum ipsi iudaei inimici nostri traderunt nobis. Et idem repetit latius in epistola a Paulinum, quae est 59., ubi exponit illud de Cain quod in figuram huius non occidisset fratrem, posuit Deus signum in illo ne quis eum occideret. Si ergo ecclesia a iudaeis accepit libros et iudaei non habent illos in canone. Ergo nec ecclesia debuit eos recipere pro canonicis. Et confirmatur hoc quia ut doctores fatentur, libri veteris legis servabantur in arca testamenti quod comprobant ex illo Deutero. 31., ubi Moyses praecepit leviticis dicens: Tollite librum istum in latere arcae foederis domini Dei vestri.

\footnotetext{
${ }^{175}$ Ms. librum.

${ }^{176} \mathrm{Ms}$. ecclesiam.
} 
[R.b.30] Et ita est verisimile quod Iosue probavit ${ }^{177}$ postea historiam suam et ita deinceps. Sed illos 5. libros non est verisimile fuisse in arca postquam hebraei non habebant pro canonicis. Ergo nec etiam ecclesia debuit recipere. Et confirmatur hoc quia Augustinus 15. de civitate Dei c. 23. dicit librum illum Enoch, cuius meminit in sua canonica Iudas apostolus, ob nimiam vestustatem non fuisse custoditum in arca et propterea non haberi postea pro canonico licet aliqua verba illius habuerint auctoritatem postquam ille citat apostolus. Item ergo esset dicendum de istis libris. Nam ut auctor est Damascenus libro $4^{\circ}$. capitulo 18., libri Sapientiae, Salomonis, Ecclesiasticus quae non servabantur in arca cum aliis libris. Et eadem est ratio de Tobia et Iudith et lib. Machab. Et ideo Damascenus non computat eos propter hoc inter canonicos. Ad haec respondetur. Primo, licet nunquam fuerint observati libri apud iudaeos in tanta custodia, ecclesia habuisset auctoritatem recipiendi illos pro canonicis quemadmodum inquit Irenaeus li. 3. c. 21. et Tertullianus libro de habitu muliebri. De libris legis dicit quod cum in captivitate babylonica essent igni absumpti, postea Esdras eodem spiritu reparavit quo Moyses scripserat. Sed Hieronymus ad Elvidium hoc sub dubio relinquit. Nam potuit esse quod licet libri qui erant in templo fuissent assumpti. Forte erant alii libri apud alias personas particulares qui haberent eandem auctoritatem postquam recepti fuerunt ab ecclesia hebraeorum. Et a fortiori ecclesia Christi haberet auctoritatem canonicandi hos libros licet hebraei non habuerint pro canonicis. Et quod dicit Augustinus quod iudaei sunt testes, hoc dicit ad maius testimonium apud gentes et potissimum ad convincendum ipsos iudaeos.

[R.b.31] Et ad aliud argumentum dicimus primo quod non est certum quod observaverunt ${ }^{178}$ in arca nisi solum 5. libros legis licet Augustino forte suspicatio fuerit, alias etiam libros observari in arca, in qua opinione etiam fuit Damascenos. Et possumus hoc colligere ex illo $4^{\circ}$. Regum 22., ubi dicitur quod Elchias pontifex invenit inter thesauros templi librum legis et Iosephus libro 10. antiq. c. 4. eadem verba referens dicit quod invenit sacrum librum Moseos nec invenit aliorum. Sed quicquid fuerit in primitiva synagoga iudaeorum, tamen post regressum a captivitate, non erat tanta cura custodiendi librum legis et maxime prope adventu Christi nec sine causa possemus suspicari quod sadducaei qui ut habetur Matth. $22^{\circ}$. et Act. 23. negabant resurrectionem, detruncarunt de canone [fol. 260r] librum Tobiae et li. Machabaeorum ubi tam lata fit mentio de cura mortuorum habenda, quod est testimonium resurrectionis. Et Iohannes Ammonius ${ }^{179}$ lib. $14^{\circ}$. super philosophiam dicit

\footnotetext{
${ }^{177}$ Ms. provavit.

${ }^{178}$ Ms. observaberunt.

${ }^{179}$ Ms. Io. Amns. Creo que quiere decir Iohannes Ammonius.
} 
librum Machabaeorum Iosephum primum habuisse por apocrypho, et quicquid fuerit de hoc, licet Deus non revelaverit ecclesiae vel synagogae illos libros divino spiritu fuisse conscriptos, hoc tamen revelavit ecclesiae.

[R.b.32] Ultimum argumentum est quod illi libri sunt apocryphi. Nam apocryphus liber ut nomen graecum sonat est liber sine auctore, id est cuius auctorem ignoramos, tamen de Ecclesiastico et de libro Sapientiae dicit Augustinus 17. de civitate c. 20 . et $2^{\circ}$. de doctrina christiana c. 8 . quod licet propter eloquii similitudinem dicatur Salomonis, tamen non esse ipsius doctores non dubitant, et dicit illos fuisse conscriptos a quodam Iesu filio Syrach. Et licet 2. retractationum c. 4. hoc modo, retentet dicens quod postea probabilius comperit non esse illum auctorem illorum, tamen non dicit quis fuerit auctor. Et pariter de Iob et aliis dubitatur.

[R.b.33] Hic nolumus disputare de auctoribus istorum librorum, quia nihil certi possumus definire nec aliquis hactenus difinivit. Vide de hoc dominum Driedo qui omnia fere colligit li. $1^{\circ}$. d. 3. Damascenus li. 4. c. 18. de solo Ecclesiastico dicit quod fuit scriptus a patre Syrach hebraice et postea interpretatus est graece a nepote suo Iesu filio Syrach et hoc apparet ex ipso prologo libri illius, ubi dicit auctor: avus meus. Sed de Sapientia Salomonis communis opinio est quod fuit conscripta a Philone, non illo qui fuit post Dominum, nam sunt in libro Sapientiae prophetata et dicta de passione Domini, sed ab alio Philone qui precessit Christum 160. annis vel ab ipso Salomone, ut multi dicunt, quod non intendimus hic disputare, sed quod ad rem attinet dicendum quod liber dicitur ${ }^{180}$ apocryphus uno modo cuius auctor ignoratur iuxta nominis ethimologiam, alio modo de quo dubitatur an fuerit scriptus a Spiritu Sancto, et isti primi reputantur apocryphi in ecclesia, unde licet dubitetur de illo qui scripsit librum Iob, et de auctoribus multorum psalmorum etiam dubitatur. Cum etiam de ipso Pentatheuco adhuc dubitatur an sit ille quem scripsit Moyses vel quem scripsit post captivitatem Esdras, sed nihilominus non dicendi ${ }^{181}$ apocryphi quia non dubitatur Spiritu Sancto dictante fuisse conscriptos. Et idem dicimus de istis 5. libris.

[R.b.34] Sed postquam quispiam circa hoc dubitaret ${ }^{182}$ an potuit fieri quod aliquis liber non fuisset scriptus ex inspiratione Spiritus Sancti, tamen postea fuisset recepto in canonicum ex inspiratione Spiritus Sancti, v. g. historia Tobiae et historia Machabaeorum fuerit conscripta ab aliquo veracissimo auctore, sed humano modo sicut nunc scriberet aliquis anales imperatorum, et tamen tam verae essent scriptae illae historiae quod postea Spiritus Sanctus

\footnotetext{
${ }^{180}$ Ms. dicitur (repetido).

${ }^{181}$ Ms. dicendum.

${ }^{182}$ Ms. dubitare.
} 
revelasset ecclesiae quod illa est infallibilis veritas et videtur quod hoc potuit fieri. Nam non est dubium quin potuit humano modo scribi vera historia in qua nec unum iota esset falsum, quare non possit postea Spiritus Sanctus revelare ecclesiae ut reciperet illam historiam sicut potuit revelare apostolo ut scriberet de novo? Nam idem profecto esset quod Spiritus Sanctus revelasset ecclesiae quod historia, v. g. Livii est usque ad ultimum iota vera et inspirasset alium ut scriberet illam. Nam licet [Livius] quando scribebat potuit errare, sed postquam scripsit atestationem Spiritus Sancti quod non erravit, iam haberet auctoritatem divinam.

[R.b.35] Et confirmatur. Iudas apostolus citavit sententiam Enoch, qui tamen liber ut dicit Augustinus etiam apud iudaeos non erat canonicus et per consequens erat scriptus humano more. Et tamen illa sententia quam dixit Enoch habet auctoritatem divinam [fol. 260v] quia revelatam est Iudae quod ille verum dixerat. Ergo quod non fuit scriptum a Spiritu Sancto potuit postea revelari tanquam canonicum. Et exprese Paulus Actuum 17. dicit atheniensibus quod hoc ipsum quod habebant scriptum in ara ignoto Deo praedicabat eis. Ecce quomodo verbum illud humanitus conscriptum revelatum est illis per Paulum esse verum, ita ergo potuit fieri quod isti libri essent conscripti humanitus et postea Spiritus Sanctus testificatus est ecclesiae esse veros.

[R.b.36] Ad hoc ego dico primo quod hoc sufficisset ad hoc ut libri illi essent canonici, quod licet essent conscripti humano more, revelaretur ese veros. Nam iam haberent testimonium divinum. $2^{\circ}$. dico quod nulla est repugnantia quod alia parva historia quae contingeret in praesentia scriptorum, ita vere scriberetur ut non repugnaret postea testificari a Spiritu Sancto. Dico parca et in praesentia, quia longa et de absentibus hoc esset dificillimum. $3^{\circ}$. dico quod de facto non est verisimile quod ita fuit, sed quod omnes libri quos ecclesia habet pro canonicis, fuerunt scripti revelante Spiritu Sancto ut docet Petrus in sua canonica. Non voluntate, inquit, humana allata est prophetia. Licet hoc latuit aliquando, et postea revelatum est.

[R.b.37] Ultimum dubium est hic postquam ecclesia habet auctoritatem recipiendi libros et succesive recipit, an nunc habeat auctoritatem recipiendi plures ita ut numerus augeatur. Hoc movo propter Ubaldensem, qui tomo $1^{\circ}$. li. 2 . c. $2^{\circ}$. tenet partem negativam, nam [negabat ${ }^{183}$ ] Ubicleff auctoritatem ecclesiae in recipiendis libris canonicis et faciebat argumenta, nam alias posset ecclesia pro libito recipere in canonem quoscumque libros sine termino. Respondet Ubaldensis negando quod possit iam augeri numerus librorum canonicorum. Et dicit quod sicut eadem est virtus in homine iam

${ }^{183}$ Negabat. Falta en el manuscrito; pero es posible que se deba a olvido del copista ya que no hay verbo y, probablemente, el que falta es: negabat. 
adulto quae erat in puero, tamen iam non potest crescere, ita ecclesia, licet habeat auctoritatem quam habuit prius, tamen quia iam venit ad plenitudinem temporum, ut dicit Paulus, non potest augeri scriptura.

[R.b.38] Sed hoc sane est intelligendum. Solum enim intendit dicere quod non potest ecclesia pro libito recipere quemcumque librum, nam in recipiendis libris uti traditione debet, vel saltem coniecturis patrum praecedentium usque ad apostolos. $2^{\circ}$. vult dicere quod non est opinabile esse aliquem divinum librum modo quin iam in 1500. annis ante non fuerit revelatum ecclesiae. Sed non negat quin si ecclesia determinaret modo aliquem librum esse canonicum, non esset habendus pro canonico, perinde ac si determinasset aliquem articulum fidei. Ecce de libris veteris testamenti.

[R.b.39] Libri novi testamenti ut diximus sunt numero 27, quorum 20. Nisi apud homines manifeste haereticos nunquam fuit dubitatum fuisse canonicos, ut refert Eusebius libro 3. c. 25. De reliquis 7. aliquando etiam inter catholicos fuit dubium ut ipsemet refert ibidem, scilicet de canonica Iacobi, $2^{\text {a }}$. Petri, $3^{\text {a }}$. Ioannis, de epistola Iudae, de Apocaypsi. Nec refert plures ibi. Sed fuit etiam aliquando dubia epistola ad Hebraeos, ut ipsemet refert eodem libro c. $3^{\circ}$. Et Hieronymus de viris illustribus ${ }^{184}$ in Gaio ${ }^{185}$. Sed nec de istis constituimus disputare quia iam non est in dubium inter catholicos. De epistola Iacobi dicit Hieronymus ${ }^{186}$ de viris illustribus quod, licet aliquando fuerit de illa dubitatum, tamen iam paulatim tempore procedente obtinuit auctoritatem. Et solus est Lutherus cum suis complicibus qui eius auctoritatem voluit refringere propter hoc quod dicit quod fides sine operibus mortua est, ubi confunditur haeresis eius, scilicet quod sola fides satis est ad salutem. Et liber Apocalypsis licet refert Eusebius et alii [fol. 261r] aliquando fuerit disputatio et in concilio laodicaeno non fiat mentio de illo, tamen Dionysius coetaneus apostolorumnumerat tanquam canonicum et in concilio carthaginensi $3^{\circ}$. et in concilio toletano 4. c. 16. et in concilio florentino et ab Innocentio et a Gelasio pontificerecipitur tanquam scriptura canonica.

[R.b.40] Et Hieronymus connumerat multos auctores gravissimos qui illum glossaverunt cum Dionysio ${ }^{187}$ : Alexander episcopus Milleto, Hipolitus, lrenaeus. Et ab eisdem conciliis recipiuntur fere ornnes epistolae quae aliquando fuerant dubiae. Sola est epistola ad Hebraeos de qua inter viros non

\footnotetext{
${ }^{184}$ Ms. illustris.

${ }^{185}$ Ms. Gayo.

${ }^{186} \mathrm{Ms}$. Ieronimus.

${ }^{187}$ Ms. Dionysium.
} 
contempnendae ${ }^{188}$ auctoritatis modo dubitatur, inter quos dominus Caietanus post alios germanoscontendit multis probare tria circa illam epistolam. Primum, quod non fuit scripta hebraeice ut habet communis opinio. $2 u m$., quod non fuit Pauli. Et 3 um quod non habet auctoritatem divinam ex qua valeat argumentum efficax educi in fide. Et potissimum eius argumentum est quod Hieronymus qui est regula in libris canonicis recipiendis dubitavit illam esse Pauli, quod argumentum accepit ab aquilone unde pendet omne malum. Maluissem certe nunquam Caietanum haec verba dixisse quam adversus eum hic disputare, sine quo non possumus hic honorem quem illi debemus, et alias solemus deferre.

[R.b.41] Nam certe primum quod ipse dicit videtur temere assertum quippe universis fere auctoribus et levissimo argumento contradicat. Et alterum est, vel saltem videtur esse errorem vel contra determinationem ecclesiae. Sed 3 um. peiori adhuc nomine est censendum. Et primum, scilicet quod fuerit scripta hebraeice non possumus aliter probare quam ex antiquissimis auctoribus, et tamen Clemens alexandrinus episcopus apostolis proximus ut refert Eusebius libro $1^{\circ}$. c. 11 . dicit quod epistola ad Hebraeos manifeste est Pauli et hebraeo sermone conscripta tanquam hebraeis. Et Origenes ut refert eodem libro c. 18. vehementius asserit. Dico inquit, sicut mihi a maioribus traditum est, quia manifestissime Pauli est, et semper omnes antiqui maiores nostri, ita eam ut Pauli epistolam susceperunt, sed aliqui, inquit, dicunt quod Clemens apostolorum discipulus, alii autem quod Lucas graeco sermone exposuerit. Ecce non erat dubium quin esset scripta hebraeice. Sed dubium erat solum de traductore.

[R.b.42] Et Hieronymus de viris illustribus ita dicit de eadem epistola. Scripserat, inquit, Paulus ut hebraeus hebraeis hebraeice. Et ne plures commemorem quotquot dicunt cum fuisse Pauli dicunt subinde fuisse scriptam hebraeice. Et confirmatur, nam primi auctores qui asserunt fuisse hebraeicam sunt graeci quibus in hac parte maxime credendum est. Nam de ipso stilo potuissent coniicere, non fuisset primo scriptam graece, vel quod est verisimile, ipsi viderunt exemplar hebraeicum, alias non habuissent pro tam indubitato fuisse hebraeicam. Argumentum istorum est quod in eadem epistola c. $7^{\circ}$. habetur Melchisedech rex Salem. Primum quidem interpretatur rex iustitiae, deinde rex Salem, quod est rex pacis. Cum ergo illud nomen Melchisedech sic hebraeicum idem pollens quod rex iustitiae, sequitur quod non fuit interpretatus per verba hebraeica, alias habuisset dicere Melchisedech, quod est Melchisedech. Ergo est dicendum, vel quod illa verba non fuerunt scripta ab apostolo sed postea adiecta ab interprete, vel epistolam non fuisse

${ }^{188}$ Ms. contempnendae. 
[fol. $261 \mathrm{v}$ ]scriptam hebraeice, vel non est asserendum, quia tunc interpretatio ipsa non esset de canone. Ergo epistola non fuit scripta hebraeice.

[R.b.43] Ista collectio multis modis peccat. Primo, eodem modo possent concludere isti quod evangelium Matthaei non fuit scriptum hebraeice propter illud Matth. $1^{\circ}$. Emmanuel, quod est interpretatum nobiscum Deus, et tamen illo non obstante Hieronymus non uno loco tantum, sed ubique suorum operum asserit Matthaeum hebraeice scripsisse, immo de viris illustribus dicit se vidisse exemplar hebraeicum, ad quod Erasmus ${ }^{189}$ quem in hoc sequitur Caietanus respondere non potuit nisi insinuando quod Heronymus in hoc mentitus est. Ita insinuat in apologia adversus Stunicam, et videte quo argumento prorumpit in illam impudentiam. Quia, inquit, si Hieronymus illud vidisset, citasset aliquando verbum hebraeicum, quod nunquam fecit. Et subiunxit Erasmus. Cur igitur Hieronymus affirmat se vidisse. Quid suspicer, inquit, mallem coniectari lectorem quam me proloqui. Insinuat certe quod Hieronymus falso dicat se vidisse. Hieronymus asserit. Erasmus negat. Censete cui sit credendum. Eo vel maxime quod Hieronymus verba hebraeica nonnunquam citat, nam in epistola ad Elvidium super illud: Vespere autem sabbati, mihi inquit, videtur evangelium Matthaei ${ }^{190}$ qui hebraeico sermone scripsit non tam vespere dixisse quam sero, et eum qui interpretatus est interpretatum esse non sero, sed vespere. Et in epistola ad Damascenum dicit hosanna ${ }^{191}$ quod Matthaeus hebraeico sermone scripsit posuit Barrama, quod est hosanna in excelsis.

[R.b.44] Sed videte pertinaciam istorum postquam ceperant defendere suas opiniones. Dicit Erasmus quod illa verba desumpsit ex evangelio Nazaraeorum, non tamen ex hebraeico Matthaei. In istas ergo angustias necesse est incidant isti. Nos tamen aliter argumentamur. Hieronymus in pluribus quam 10. Locis asserit Matthaeum scripsisse hebraeice et nullibi unquam de hoc dubitavit et praeter Hieronymum Augustimus, Chrisostomus, Origenes, Clemens, Alexander, Tertullianus, Damascenus. Irenaeus et ipse Papias qui fuit discipulus Ioannis pro indubitato ubique asserunt Matthaeum scripsisse hebraeice. Nam ut dicit Hieronymus scripsit evangelium propter eos qui de circumcissione crediderant, nam postquam praedicaverat in Iudaea et voluisset transire ad gentes constituit relinquere iudaeis praedicationem suam in scriptis. Ergo indubie tendendum est quod Matthaeus scripsit hebraeice, et nihilominus omnes isti patres viderunt illud Emmanuel quod interpretatur nobiscum Deus et similes locutiones. Ergo nullum argumentum insumptum

\footnotetext{
${ }^{189}$ Ms. Herasmus.

${ }^{190}$ Ms. Mattaheum.

${ }^{191}$ Ms. osanna.
} 
debet nos trahere contrariam in sententiam, sed potius credendum nos nescire solvere quam contradicendum universali scholae sanctorum. Quod certe sine temeritate facere non possumus. Hoc dixerim ad concludendum quod licet sciamus solvere argumentum Caietani, non tamen concludendum erat quod epistola non fuerit scripta hebraeice.

[R.b.45] Et miror unum Caietani ${ }^{192}$, quod ad negandum epistolam dicit quod habenda est regula sententia Hieronymi qui illud dubitat et quando vult negare quod Matthaeus scripsit hebraeice, nihil facit Hieronymum qui oppositum indubie ubique asserit, sed videamus an possimus respondere ad argumentum et primum. Quantum attinet ad Matthaeum dicit quidam modernus non contemnendo auctoritatem [fol. 262r] quod post regressum a captivitate Babylonis multa erant vocabula chaldaeica permixta hebraeicis, quia Matthaeus scribens chaldaeica posuit et hebraeice expressit ut est illud Matthaei 27 golgotha $^{193}$, quod est calvariae locus. Golgotha chaldaeicum est et interpretatum hebraeice. Et illud eppheta ${ }^{194}$ quod est aperire. Et illud lama sabathani.

[R.b.46] $2^{\circ}$ dicimus quantum ad illud Matth. $1^{\circ}$. Emmanuel quod est interpretatum, nam Emmanuel hebraeicum est et idem quod nobiscum Deus. Damus quidem hoc quod illa intepretatio sit interpretis quantum non sequitur quod non sit canonica. Primum, quia est verisimile quod evangelium fuit traductum tempore apostolorum. Nusquam hoc legimus, sed videtur mihi recte coniicere et ideo fuit ab ipsis apostolis translatio recepta, unde sicut diximus in superiori relectione quod Lucas et Marcus habent auctoritatem canonicam quia fuerint recepti ab apostolis, ita etiam traducens Matthaeum et epistolam ad Hebraeos, et ideo illae interpretationes licet essent additae ab interprete, nihilominus sunt canonicae censendae.

[R.b.47] Sed aliter adhuc mihi videor Achillem istum iugurare. Existimo enim quod licet illa verba sint addita ab interprete nec ab apostolis approbata, nihilominus tamen sunt censenda ${ }^{195}$ canonica quod miror non advertisse quotquot versati sunt in hoc argumento solvendo, quod sic palam facio. Si interpres non servasset nomen hebraeicum, v. g. Emmanuel, sed traduxisset nobiscum Deus, manifestum est quod illa verba tunc essent de canone quia fideliter tractatum esset nobiscum Deus. Sed interpres graecus non potuit ita transferre, nam illa verba non habent formam nominis proprii sicut Emmanuel, et ideo necesse ei fuit utrumque, et servare nomen hebraeicum et transferre

\footnotetext{
${ }^{192}$ Ms. Caietanum.

${ }^{193}$ Ms. golgota.

${ }^{194}$ Ms. effeta.

${ }^{195}$ Ms. censendae.
} 
nobiscum Deus. Et illud non potuit commode fieri nisi interiecta particula, quod est aut quod interpretatur. Quod totum censendum est de canone, nam particula quae adiicitur ad servandum congruitatem non vetat quin totum sit de canone.

[R.b.48] Fateor tamen quod in $7^{\circ}$. c. ad Hebraeos non potest dici quod illa interpretatio fuit adiecta ab interprete. Immo videtur esse ipsius auctoris vel interpretis saltem recepti ab apostolis. Hoc patet ex ipso contextu litterae. Habetur enim: Hic enim Melchisedech rex Salem sacerdos Dei Summi. Et sequitur primum quidem: qui interpretatur rex iustitiae. Deinde autem rex Salem, quod est rex pacis sine patre sine nomine. Sunt enim omnia verba sub eodem contextu, scilicet primum rex iustitiae etc., sine patre etc., et ideo ídem auctor qui posuit posterius sine patre praemiserat primum quidem. Et confirmatur hoc. Nam superius c. $5^{\circ}$. cum dixerat de Christo quod appellatus est a Deo pontifex iuxta ordinem Melchisedech subiungerat. De quo nobis grandis sermo et interpretabilis addicemus. Unde illud quod tunc dixerat interpretabile, interpretatur c. 7.

[R.b.49] Sed tunc [fol. 262v] quomodo respondebimus Caietano? Si Paulus scripsit hebraeice quomodo interpretatus est hebraeice Melchisedech, quod est rex iustitiae? Respondemus quod forsan illud nomen Melchisedech, licet significet rex iustitiae, forsan est aequivocum et habet alias significationes, et ideo expressit mysterium ${ }^{196}$ per alia nomina non aequivoca vel dicendum quod litterate melchi non est nominativus nec sedech genitivus. Et ideo expressit per genitivum et nominativum. Ita dicit Chrisostomus Melcha rex Salem iustitiae, sicut si quis latine interpretaretur signifer, id est signum ferens. Quod non fecit Paulus ad explicandum obscuritatem nominis quod clarum erat, sed ad exagregandum, ad exaggerandum, divinum mysterium quod per illud nomen significabatur: Christus. Vel ultimum dicendum, quod Paulus scripsit hebraeice epistolam quam Lucas tempore apostolorum transtulit graece. Unde ipsa translatio fuit accepta ab apostolis et ideo quicquid addidisset Lucas fuit canonicum.

[R.b.50] Alterum dictum Caietani peius est, scilicet quod illa non fuerit Pauli epistola, nam praeter auctores citatos Eusebius, Clemens, Alexandrus, Origenes qui dicunt manifestissime esse Pauli, et ita maiores ubique docuisse. Est Dionysius discipulus ipsius Pauli qui frequenter citat illam epistolam tamquam magistri sui. Nisi ut omnia negant, negaverint etiam illum fuisse Dionysium Areopagitam, sed ne plures auctores qui plurimi sunt commemorem. Primitus, ut refert s. Thomas, fuit recepta in concilio Nicaeno. Et ita refert in prologo eiusdem epistolae. Quod scilicet fuerit dubia ante illum

\footnotetext{
${ }^{196}$ Ms. misterium.
} 
concilium, tamen tunc fuit recepta. Et licet illud decretum non sit modo in actis concilii, tamen illud est verisimile. Nam statim in concilio carthaginensi $3^{\circ}$. Et Innocentius 1us. in epistola ad Exuperium c. 7. et Pelagius cum 70. Episcopis eam recipiunt. Et tandem in concilio florentino est recepta, nec valet si dicatur quod non est recepta tanquam de fide postquam eodem tenore ${ }^{197}$ recipitur quo alii libri sine nota aliqua distinctionis ${ }^{198}$. Et Chrisostomus in homilia super eandem epistolam indubie asserit illam fuisse scriptam Romae a Paulo. Et certe si istis placeret, abunde deberet probare universus usus ecclesiae, quae legit et praedicat eam tanquam Pauli.

[R.b.51] Accedit testimonio huius primo argumentum ipsius epistolae. Certe dignum Paulo. Contendit enim in tota epistola ostendere excellentiam Christi et sacerdotii illius ad sacerdotium veteris legis. Et quemadmodum lex iam cessaverat nec eam concurreret ${ }^{199}$ cum evangelio, quod fuit etiam argumentum epistolae ad Galatas adversus conversos ex iudaismo qui erant in illo errore, nec est verisimile quod Paulus qui anathema cupiebat esse pro fratribus, non aliquid ${ }^{200}$ scriberet ad Hebraeos de fide Christi ex apostolis, vel maxime Paulum ex iudaismo conversum illam scripsisse. Accedit $2^{\circ}$. tam varia veteris testamenti expositio quod ista epistola frequentissima est, unde colligitur vel ex apostolis vel maxime Paulum ex iudaismo conversum illam scripsisse. Accedit $3^{\circ}$, quod multa in eadem epistola recipiuntur germana eorum quae in aliis epistolis exparserat. Et $4^{\circ}$ zelus ${ }^{201}$ ferventissimus quo invehitur per totam epistolam, qui vel solus manifestissime Paulum refert, [fol. 263r] et tandem vel illud comprobat quod in calce epistolae conmendat apud eos Timotheum per quem epistolam mittit et iubet salvere omnes praepositos. Et quis poterat mittere epistolam per Timotheum nisi Paulus qui eum individuum comitem habebatur? Certe qui viderit expositionem Chrisostomi super illam epistolam et quaelibet verba ad spiritum Pauli commodet, non dubitabit certe illam epistolam ese Pauli.

[R.b.52] Sed quod $3^{\circ}$ et postremo adiecit Caietanus, videlicet ex epistolae huius auctoritate ${ }^{202}$ non posse determinari dubium quod in fide accideret multo peius est. Nam licet non constaret esse Pauli, non subinde sequitur ut colligit Caietanus quod non sit canonica. Nam multi sunt psalmi de quorum auctoribus

\footnotetext{
${ }^{197}$ Ms. thenore.

${ }^{198}$ Ms. distinctionibus.

${ }^{199}$ Ms. concurrere.

${ }^{200}$ Ms. aliquit.

${ }^{201}$ Ms. celus.

${ }^{202}$ Ms. auctoritatem.
} 
dubitamus et non dubitamus esse canonicos. Et historia Iob, Esther et Iudicum non habent certos auctores, tamen ecclesia certa est quod sunt scripturae divinae, ita possemus dicere de epistola ad Hebraeos. Nam ut ipsum locum Hieronymi citemus quem pro se Caietanus citat, licet dicat Hieronymus quod non ab omnibus creditur Pauli, tamen dicit omnes unanimiter consentire ese vel Barnabae vel Lucae vel Clementis. Et quicumque illorum scripsisset eam, verisimile est sciripsisse tempore apostolorum, a quibus proinde recepta est sicut evangelium Lucae et Acta apostolorum. Sed in hoc non amplius moror, quia non censeo dubitemus quin certo sit Pauli, ut probatum est.

[R.b.53] Primum argumentum istorum et Caietani est quod Hieronymum ortiti sumus regulam in descriptione librorum canonicorum, qui tamen saepe dubitat an illa fuerit epistola Pauli. Sed primum omnium. Quare non utuntur Hieronymo pro regula cum negant Matthaeum scripssisse hebraice et in aliis multis? Deinde negamus Hieronymum esse huiusmodi regulam, saltem quod non sint modo libri canonici nisi qui erant canonici tempore Hieronymi. Nam ut diximus in $2^{\mathrm{a}}$ conclusione fundamentali ecclesia succesive recipit libros canonicos. Et si illa regula valeret, tune illi 6. libri veteris testamenti essent nullo modo canonici, immo nec epistola ad Philemonem nec $2^{\mathrm{a}}$ Petri nec $2^{\mathrm{a}}$ $3^{\text {a }}$ Ioannis, nam de omnibus dicit Hieronymus fuisse valde dubitatum, et de epistola Iacobi dicit quod paulatim obtinuit auctoritatem. Quare non dicamus idem de epistola ad Hebraeos?

[R.b.54] $3^{\circ}$ dico quod nunquam insinuat Hieronymus se dubitasse illam fuisse canonicam. Hoc erit pervium legenti omnia loca quae citat Caietanus. Nam in epistola ad Paulinum dicit sic: Paulus scripsit ad 7. ecclesias, octava enim ad Hebraeos, a plerisque extra canonem ponitur. Certe illa verba non sint dubitantis, sed solum enarrantis veram historiam. Sicut si ego dicerem modo: Epistolam ad Hebraeos non ponitur in canone ab Erasmo vel Caietano vel non semper fuit certa tanquam de canone. Certe non propterea insinuo quod ego de hoc dubito. Et eodem modo de viris illustribus in verbo Paulus primo refert quidem veram historiam, scilicet epistola ad Hebraeos non eius credatur propter stilum ${ }^{203}$ sermonisque distinctionem, sed statim subiungit suam sententiam vel certe, inquit: Ecce certe particula est [fol. 263v] asserentis, non dubitantis, quia Paulus scribebat ad Hebraeos; propter invidiam sui apud eos nominis titulum salutationis amputaverat, scripserat ut hebraeus hebraeis hebraeice. Sed Caietanus solum primum citavit et $2 u m$. praetermisit.

[R.b.55] Sed in epistola ad Evagrium ubi disputat de Melchisedech, quia utitur testimoniis illius epistolae dicit quam omnes graeci et nonnulli latinorum

${ }^{203}$ Ms. stili. 
recipiunt. Certe nec illa verba sunt dubitantis, sed potius abstinentis ${ }^{204}$ suam opinionem, scilicet quod non inmerito citabat eam tanquam canonica. Et sic Hieronymus c. 6 . et 8 . quia utitur etiam testimoniis illius epistolae dicit quod cuiuscumque illa sit habet auctoritatem. Sed adducit aliud de viris illustribus inverbo, Gayo aut Bayo, ubi dicit quod apud romanos usque hodie quasi Paulinon habetur. Miror quod illa verba velit impingere Hieronymo, nam non sunt verba Hieronymi ut est manifestum, sed Gaii ${ }^{205}$ aut Baii ${ }^{206}$, cuius dicta refert Hieronymus. Sed magis miror quod cum tam sollicite Caietanus singula loca Hieronymi presentatu ${ }^{207}$ fuerit, non inciderit in epistolam ad Dardanum, quae incipit: Quaeris Dardane ubi haec verba sint, illud nunc dicendum est hanc epistolam quae inscribitur ad Hebraeos non solum ab ecclesiis orientis sed ab omnibus retro ecclesiasticis graeci sermonis scriptoribus quasi Pauli apostoli suscipi, licet plerique eam vel Barnabae, vel Clementis arbitrentur, et nihil interesse cuius sit cum ecclesiasticae viri sit et quotidie ecclesiarum lectione celebretur, quod si eam latinorum consuetudo non recipit inter scripturas canonicas, nec graecorum quidem ecclesiae Apocalypsim Ioannis eadem libertate suscipiuntur, et tamen nos utramque suscipimus, nequaquam huius temporis consuetudinem sed veterum scriptorum auctoritatem sequentes qui plerumque utriusque utuntur testimoniis, non ut de apocriphis sed quasi de canonicis et ecclesiasticis. Haec Hieronymus. Censete an dubitaverit Hieronymus.

[R.b.56] Et in expositione epistolae ad Titum c. 2. dicit: Relege ad Hebraeos epistolam Pauli sive cuiusqumque alterius eam esse putes, quia iam inter ecclesiasticas est recepta. Debuisset Caietanus Hieronymi studiosissimus ad haec respondisse. Obiicit deinde 2. loca eiusdem epistolae quae non videntur Paulo digna. Primum statim in $1^{\circ} \mathrm{c}$. ubi ad probandum superiorem angelis ese Christum, adducit illud 2. ${ }^{208}$ Reg. 7. Ego ero illi in patrem et ipse erit mihi in filium, quasi dictum de Christo. Cum tamen intelligatur ad litteram de Salomone et tamen non videtur quod Paulus in sensu allegorico adduxisset illud adversus iudaeos qui non recepissent illum excursum $^{209}$. Alterum est in c. 9. ubi ponit differentiam inter testamentum et pactum, ut statim annotabimus.

\footnotetext{
${ }^{204}$ Ms. astinentis.

${ }^{205}$ Ms. Gayi.

${ }^{206}$ Ms. Bayi.

${ }^{207}$ Ms. presentatus.

${ }^{208}$ Ms. 1.

${ }^{209}$ Ms. scusum.
} 
[R.b.57] Sed ad primum interim respondetur quod Paulus in tota illa epistola intendit potissimum declarare caerimonias veteris legis fuisse figuras sacerdotii Christi et non solum caerimonias, sed historias ipsas. Et ideo adduxit historiam de Salomone 2. Reg. 7. quae licet ad litteram intelligatur de Salomone, tamen intelligebatur de illo in quantum erat figura Christi. Et hoc etiam ipsi iudaei confitebantur nec illud negare poterant. Nam [fol. 264r] statim in eodem capitulo subiunguntur verba quae non possunt intelligi ${ }^{210}$ de Salomone nisi ut erat figura Christi, ut illud: et fidelis erit domus tua et regnum tuum usque in aeternum ante faciem meam, et thronus tuus erit firmus iugiter. Cum ergo iudaei non possent negare illud dici in figura de Messia, non absolute adduxit illud Paulus in sensu allegorico, nam eadem ratione contendit persuadere Galathis quod cessavit iam lex vetus per hoc quod Isaac filius liberae eiecit filium ancillae ubi per allegoriam significabatur legem veterem excludendam esse per novam.

[R.b.58] 2um. argumentum Caietani est quod in 9. capitulo contendit probare apostolus quod testamentum novum fundatum est per effusionem sanguinis Christi in cuius figura Exo. 24., postquam Moses legit verba legis populo respersit populum sanguine. Dicit Caietanus quod illic non tractabatur de testamento, sed de pacto inter Deum et populum, et ideo Paulus non adduxiisset illud in figuram, scilicet sciens differentiam esse inter pactum et testamentum. Sed certe hoc argumentum Caietani est minus dignum ipso Caietano, nam Paulus solum intendebat probare quod promissio Christi de haereditate caelesti habebat vim testamenti per effussionem sanguinis ipsius, nam testamentum est promissio haereditatis quam non licet addire nisi per mortem testatoris. Et dicit quod in figuram illius cum lex vetus promulgata fuit a Moyse, aspersit sanguinem populo ${ }^{211}$. Et peius esset si voluisset Caietanus illam fuisse figuram illius. Et vocat illud testamentum, sicut ecclesia vocat non quod haberet vim testamenti per illam sanguinem, sed quod in lege illa promittebatur haereditas quae erat habenda in morte Christi.

[R.b.59] Sed concludit tamen Caietanus quod non opus est illi coniecturae, nam apertum est illam epistolam non esse Pauli, nam auctor illius epistolae in $2^{\circ}$. capitulo connumerat se inter illos in quibus confirmata est fides ab illis qui audierant, et tamen Paulus non accepit fidem ab aliis horninibus sed a Deo inmediate. Nam, ut ipse ex professo probat ad Galatas quod non fuit electus ab hominibus sed a Deo in apostolum. Infinita argumenta multiplicat Caietanus. Primo confitetur quod illa verba potuerunt insinuare suspitionem quod essent Lucae, nam simile ipse dicit in prologo sui evangelii sicut tradiderunt nobis

\footnotetext{
${ }^{210}$ Ms. intellixi.

${ }^{211}$ Ms. populum.
} 
qui ab initio ipsi viderunt. Sed dicimus $2^{\circ}$ quod illa verba non sunt disona Paulo, nam voluit per illa insinuare quod non erat ille ex illis qui conversati sunt cum Christo, a quibus multa audierat testimonia de Christo. Nec obstat quod dicit Gala. $1^{\circ}$, quod non sit apostolus ab homine nec per hominem, nam solum intendit probare quod non sit vocatus ad christianismum per homines sed inmediate a Christo, nam usque ad articulum vocationis persequebatur ecclesiam. Item quia nec fuit destinatus in apostolum ab aliis apostolis sed a Deo, ut habetur Act. 13․ Segregate mihi Barnabam et Saulum [fol. 264v] in opus ad quod assumpsi eos, et quod ibi sequitur scilicet evangelium quod evangelizatum est a me, nec accepi ab homine nec a discipulis sed per revelationem Iesu Christi, illud scilicet intelligit quoad veritatem fidei quantum ad revelata.

[R.b.60] Cum quo tamen stat quod illa quae humano more poterant sciri didicit ab aliis ut illa quae Christus vivens gesserat coram illis. Quis dubitat quin ab Anania edoctus est multa Actuum $9^{\circ}$ et quod ille sit modus loquendi Pauli. Confirmatur. Nam Actuum $13^{\circ}$ connumerans mortem et resurrectionem Christi adducit in testes illos qui simul erant cum illo, qui usque tunc, inquit, sunt testes eius ad plebem, non se connumerat inter illos, scilicet testes vitae Christi. Et hoc est quod ibi dicit. Habetur quod fides Christi confirmata est in nos ab eis qui audierunt. Ecce ut suspicor plus satis diximus pro ista epistola ad Hebraeos.

[R.b.61] Duo tamen verba restant necessaria quae annotentur. Primum est an sint censendi haeretici qui negant istos libros esse canonicos. Et videtur quod sic postquam sint iam a pontifice et concilis recepti in canonem, quae Caietanus omnia vidit et Antoninus et Abulensis, nam Nicholaus de Lyra non vidit saltem concilium florentinum. Licet viderit alia decreta pontificum, et forte erat in illa opinione quod papa posset in istis errare. Respondemos ad hoc quod quantum ad illos 6. libros qui ante tempus Hieronyrni non fuerant in canone, Nicholaus, et etiam Antoninos et Abulensis videntes concilium florentinum potuerunt excusari quia opinati sunt non esse receptos tanquam canonicos, sed tanquam sanctorum ut dicit Antoninus. Male quidam intellexerunt concilium et decreta pontificum, sed viri tam egregii non sunt censendi haeretici. $2^{\mathrm{a}}$ dicimus quod quantum ad epistolam ad Hebraeos etiam isto modo possumus salvare Caietanum, sed tamen ut cum bona venia dixerim, non est tam excusabilis sicut alii. Primo, quia epistola ad Hebraeos semper a temporibus apostolorum fuit recepta ab omnibus ecclesiis orientalibus et graecis, ut dicit Hieronymus. Deinde, quia in hoc non est secutus aliquem doctorem gravem cum illa loca quae adducit ex Hieronymo non fuit argumentum Hieronymum fuisse illius opinionis, ut monstravimus, sed quia vela dedit vento aquiloni qui his temporibus tam adversus est ecclesiae, periclitatus est in hoc. 
[R.b.62] 2um. dubium est ultimum, an omnes libri canonici 44. Veteris testamenti et 27. novi sint eiusdem auctoritatis. Respondemus primo quod omnes sunt infallibilis veritatis, quia omnes sunt a Deo revelati. $2^{\circ}$ dico quod non sunt omnino ${ }^{212}$ eiusdem auctoritatis, quia licet omnes sint ab ecclesia recepti, non est de omnibus aequa certitudo quod sint tamquam canonici, nam ut modo diximus excusantur ab haeresi qui non credunt illos 6 . libros veteris testamenti receptos esse tanquam canonicos, et tamen non excusarentur qui hoc dicerent de evangeliis. Unde Augustinus in fronte [fol. 265r] statim libro $1^{\circ}$ de consensu evangeliorum inter omnes inquit divinas auctoritates quae sanctis libris continentur, evangelium merito excellit.

[R.b.63] Sed certe inter scripturas novi testamenti periculosissimum esset negare aliquam esse canonicam, etiamsi fuerit de illis vel de illa dubitatum, nam vel in hoc Lutherus censetur haereticus quod negat epistolam Iacobi licet de illa aliquando fuerit dubitatum. Et si solum germani negarent epistolam ad Hebraeos, nescio an de hoc etiam censeremus illos haereticos. Haec dicta sunt de catalogo librorum canonicorum. Tertium punctum propter quod potissimum istas disputationes submoveramus ${ }^{213}$ erat de sensibus sacrae scripturae. Sed video iam nullum superesse tempus ut possim illum attingere. Porte aliam relectionem expendet. Amen.

[R.b.64] Uni trinoque Domino sit sempiterna gloria. Amen.

\section{c) De sensibus sacrae scripturae (1538)}

[R.c.1] [fol. 242r] Relectio reverendi patris fratris Dominici de Soto magistri de sensibus sacrae scripturae habita Salmanticae anno Domini nostri Iesu Christi 1538. Locus relegendus: Vidi in dextera Dei sedentis super thronum librum scriptum intus et foris. Apocalyp. $5^{\circ}$. Prima conclusio. Partitio sensuum in litteralem et spiritualem sacrae scripturae propria est et fidei catholicae habet auctoritatem, atque adeo sensus spiritualis distributio in alegoricum, moralem et anagogicum, et sacra scriptura nititur et apud sanctos patres antiquissime legitur. $2^{\mathrm{a}}$ conclusio. Cum sensus ille omnis censeatur litteralis quemcumque voces vere significant, nullum est sacrum eloquium quod non in sensu aliquo litterali sit verum. Parabolae autem et similitudines sub sensu comprehenduntur litterali. $3^{\mathrm{a}}$ conclusio. Ut auctoritas una sacrae scripturae eodem loco plures habet sensus litterales, ita in diversis locis a diversis asserta aut citata sensum litteralem non mutat, sed citatur ab

\footnotetext{
${ }^{212}$ Ms. sigue: $d e$, que sobra.

${ }^{213}$ Ms. summoveramus.
} 
apostolis saepe in sensu spirituali, tametsi ex solo litterali efficax sumatur argumentum.

[R.c.2] Contendere etiam nunc persevero vestra abuti benevolentia qua me semper audire consuevistis quando de eadem re $3^{\circ}$ iam apud vos dicturus prodeo ut pene fuerim legum Flacci praetergressus qui comoediam scribit ut non sit $5^{\circ}$ productior actu. Nunquam tamen huiusmodo veniam, deprecer, si culpa modo hac carere possem, at vero cum punctum hoc fuerit quod statim ab initio statueram potissimum disputare atque adeo quod $^{214}$ duas alias relectiones intenderim rem absurdam mihi fecisse videbar, nisi instincto nostro, supremam iam manum demum adderem, eo maxime quod hoc genus argumenti, si modo pro dignitate tractetur, non est quod possit nunquam sacietatem facere, et nisi auribus nostris blandiri voluistis, vos hoc ex me et improbe quidem flagitastis, nam ita nos studia nostra conmendando animare soletis ut maiores Semper habeamus labores. At cum boni poetae ut ad Quintum fratrem commoverat Cicero in postremo actu fabulae, plurimi iam artis addere soleant quo diligentissimus atque ornatissimus videatur, nescio an id nobis in praesenti usu venerit.

[R.c.3] Est namque materia haec ut scitu dignissima, non tamen in ordinibus $^{215}$ quibus posita, ob idque non difficilia expectetis argumenta nec nodum illum veluti gordianum ab Alexandro solvendum a nobis existimetis, sed institutivum est illa quae tria sunt et consueta certis terminis pro virili nostra praescribere atque adeo in epilogum redigere. Ex tribus illis membris quae infimo temporis relectionis in disputatione protuleram, duo iam superioribus disputationibus [fol. 242v] utcumque expedita ${ }^{216}$ dedimus, primum de auctoritate sacrae scriptura, $2 \mathrm{um}$. de catalogo librorum canonicorum qui sunt in canone. Superest iam nunc extremum de sensu multiplici eiusdem scripturae disserere, ne abs re fuit praesenti anno materiam hanc relegere, nam lectura eramus si tempus suppeteret materiam de legibus ubi ea princeps est quaestio, an lex veteris legem gratiae spiritualiter sub signo praenuntiaverit, ubi campus iste large ${ }^{217}$ quam de sensibus sacrae scripturae, et quia relectio haec eodem tendit quo duae transactae, opere praetium duximus circa idem thema eam constituere, quod est illud Apoca. $5^{\circ}$ : Vidi in dextera sedentis.

[R.c.4] Et ut disputatio nostra apertius disponatur, in 6. Conclusiones statuimus eam statuere. Prima, quotnam sensus in sacra scriptura

\footnotetext{
${ }^{214}$ Ms. quo.

${ }^{215}$ Ms. ordinis.

${ }^{216}$ Ms. expedicta.

${ }^{217}$ Ms. larte.
} 
distinguantur ${ }^{218}$. $2^{\mathrm{a}}$, qua necessitate quave commoditate propriae sacrae scripturae pluribus sensibus abundet. Et $3^{\mathrm{a}}$, utrum hoc aliis etiam scientiis prophanis sit commune. $4^{\mathrm{a}}$, quae erit potissima, quisnam sensus sit censendus litteralis et utrum nullus sit locus in sacra scriptura qui non habeat verum sensum litteralem. $5^{\mathrm{a}}$, an eadem verba in scriptura plures habeant sensus litterales. $6^{\mathrm{a}}$ denum ac postrema, an ex omni et solo sensu litterali sumatur efficax argumentum in sacra scriptura.

[R.c.5] Quaestio ergo prima est de numero sensuum scripturae et de nominibus eorum. Et ut totam materiam disputationis in ipso statim vestíbulo ob oculos obiiciamus, 4or. sensus distinguunt in sacra scriptura doctores huius temporis, quod divus Thomas inter scholasticos primus et quidem graphice discribit 1. p. q. 1. ar. 10. et quodlibeto 7. q. 6. ar. 2., cuius perinde sententiae posteriores omnes suscribunt. Distinguunt ergo primo sensum scripturae in duos: litteralem et spiritualem. Mox spiritualem subdividunt in allegoricum, moralem et anagogicum. Litteralis ut exactius videbimus q. 4., est ille qui habetur ex significatione qua voces significant res sive proprie sive metaphorice. Proprie, ut Dominus Deus tuus ${ }^{219}$ unus est, Deut. 6.; methaphorice, ut Deus noster ignis consummens est. Ad Hebraeos 12. spiritualis sensus censetur secundum quod res significative per voces institutae sunt ad designandum alias res. Etsi sint res veteris legis significantes futurum aliquid in lege gratiae, faciunt sensum allegoricum, ut duo filii Abrahae quos apostolus ad Gala. 4. allegorice docet significare duo testamenta.

[R.c.6] Si autem res significant aliquid pertinens ad mores, reddunt sensum moralem seu tropologicum, ut praeceptum illud Deut. 25. Non alligabis os bovis $^{220}$ triturantis. Ad litteram significat id quod sonat, sed factum ipsum moraliter significabat quod praelati ob labores spirituales digni sunt stipendio temporali, ut idem apostolus exponit 1. Cor. $9^{221}$. Et factum illud Christi Matth. 21., quando proficiens de Hierico sedens super asinam et pullum intravit in Hierusalem praeeuntibus et subsequentibus cantantibus: Hosanna in excelsis, per analogiam designavit modum qua Christus conversos ex utroque populo introductus est in caelestem Hierusalem. Et praeter alias Hieronymus et Remigius $^{222}$ exponunt hos 4or. sensus. Declarant exemplo illius dictionis Hierusalem, quae literaliter significat urbem illam celeberrimam, sed civitas

\footnotetext{
${ }^{218}$ Ms. distingantur.

${ }^{219}$ Ms. finis.

${ }^{220}$ Ms. vovi.

${ }^{221}$ Ms. 6.

${ }^{222}$ Ms. triunfantem.
} 
ipsa moraliter significat animam nostram, allegorice vera militantem, et anagogice triumphantem. [fol. 243r] Unde versus littera gesta docet, quid credas allegoria. moralis quid agas, quo tendas anagogia. Haec sunt apud neothericos vulgata et certa circa quae versabimur in praesenti disputatione.

[R.c.7] Et primum omnium circa nomen sensus dubium parvum est per quae accipitur quando dicimus haec aut illa verba habere talem aut plures sensus, utrum accipiatur pro ipsa significatione vocis aut rerum, aut pro conceptu mentis quem voces generant. Ad quae sub brevibus respondemus. Nomen sensus ut manifestum est significat primo potentias corpóreas apprehensivas ut visum et auditum. Transfertur tamen ad significandum conceptum mentis vel iudicium quod vocant animi sententiam, unde Quintilianus libro 5. quod est de generalibus sententiarum. Illud, inquit, quod animo sentimus sententiam veteres vocaverunt; et subiungit, nec raro sic locuti sunt ut sententias sensata dicunt, nam sensus corporis videbantur, sed consuetudo iam tenuit ut mente concepta sensus vocaremus. Haec Quintilianus.Conceptus ergo mentis latine dicuntur et sensata et sensus, et ita sensus accipitur generaliter pro intelligentia, unde quando dicimus: Haec verba faciunt talem sensum aut talis sensus dicitur ex his verbis, illic sensus formaliter accipitur pro intelligentia seu conceptu mentis, et eodem modo potest accipi quando dicimus: Hic est sensus huius litterae, ut hic sensus sit causalis.

[R.c.8] $2^{\circ}$ dicimus quod sensus etiam accipitur pro ipsa significatione vocum, ut in hac ultima propositione. Nam sicut nomen potentiae derivatur ad actum ipsius potentiae quem assensum principiorum vocamus intellectum, ita e contrario nomen sensus quod dicitur de conceptu derivatur ad significationem vocum perquem generatur conceptus. Ethos quos iam vocamus sensus scripturae saepe doctores vocant intelligentias. Ita Hieronymus in prologo bibliae dicit in verbis singulis Apocalipsis multiplices litterae intelligentias, quod est apud alias etiam doctores frequentissimum et in sacra scriptura vocantur isti sensus, ut Sapientiae ${ }^{223}$ 7. Optavi et datus est mihi sensus. Et I. ad Cor. 2. Nos autem sensum Christi habemus, et alibi saepe. Circa divisionem illam vulgatam: 4or. sensus, animadvertendum est quod apud veteres non distinguebantur nisi duo sensus scripturae, scilicet spiritualis et litteralis, nec subsecabant spiritualem sub diversis nominibus in allegoricum et anagogicum, sed promiscue sensum reconditum sub litterali vocabant spiritualem et mysticum ${ }^{224}$ et allegoricum. Frequentissima sunt exempla sanctorum exponentium scripturam quam ut opus sit testimonium hic afferre.

${ }^{223}$ Ms. Sapientiae, al margen y para que se entienda bien claramente lo que está escrito en el cuerpo.

${ }^{224}$ Ms. misticum. 
[R.c.9] Sed dubium est an illa divisio inventa sit solum a patribus an sit etiam de fide quod sacra scriptura sub sensu litterali contineat alium spiritualem et vocamus spiritualem illum solum quem res ipsae gestae significant. Ad quod respondemus quod non solum est inventum doctorum sed est fides catholica sacram scripturam habere sensum spiritualem et oppositum est haeresis manifesta. Et hoc sit fundamentum huius nostrae disputationis patet. Apostolus ad Gala. $4^{\circ}$ exponit historiam duorum filiorum Abrahae spiritualiter per allegoriam de duobus testamentis. [fol. 243v] Et 1. ad Cor. 10. Nolo, inquit, vos ignorare fratres et patres nostri omnes in Moyse baptizati sunt in nube et in mari, et omnes autem escam spiritualem manducaverunt, et omnes eundem potum spiritualem biberunt. Et postquam singula conmemorat, tandem in summa colligit: Haec omnia in figura contingebant illis. Et Petrus 1. Per. $3^{\circ}$ arcam Noe late ${ }^{225}$ exponit tanquam figuram ecclesiae. Et loann 19. Occisionem agni paschalis docet fuisse figuram Christi citans illud Exod. 12. Os non conminuetis ex eo, quod impletum est in Christo. Nec apostoli solum sed Christus ipse liberator noster legem veterem in sensu spirituali. et ponit de se ipso. Sicut fuit, inquit, lonas in ventre ceti tribus diebus et tribus noctibus, sic erit Filius hominis in corde terrae Matth. 12. Et loan. 3., sicut Moyses exaltavit serpentem in deserto, ita exaltari oportet Filium hominis.

[R.c.10] Sed supervacaneum est in re non dubia uti textibus non necessariis. Divisio illa bimenbris sub illis nominibus sensus litteralis et spiritualis desumpta est de locis frequentibus apostoli. 2. ad Cor. 3. Sufficientia nostra ex Deo est, qui idoneos nos fecit ministros novi testamenti, non litterae sed spiritus, id est non secundum litteralem sensum, ut antiqui intelligebant secundum spiritualem quare subiungit. littera occidit spiritus aut vivificat. Quod Augustinus 3. de doctrina christiana cap. 5. exponens ait quod littera occidit eos quibus spiritualiter sit intelligenda vel figuraliter literaliter intelligunt. Et 1. ad Cor. 10. Omnes patres nostri eandem escam spiritualem manducaverunt et omnes eandem potum spiritualem bibunt. Et ad Roma. 7. Nunc soluti sumus a lege mortis ut serviamus in novitate spiritus.

[R.c.11] Quae omnia loca apostoli congerit Hieronymus ad Gala. 4. Ad comprobandum duplicem hunc sensum scripturae, litteralem et spiritualem. Ait enim legem fuisse spiritualem propter sensum allegoricum quem continebat sub litera, unde manna et subiti fontis eruptionem ${ }^{226}$ eo quod allegorice accipienda sunt spiritualem cibum et potum vocat apostolus. Et Origenes super Leviticum homilia 7. eodem modo exponit illud: littera occidit, spiritus autem vivificat, de sensu litterali et spirituali, et appellatur sensus spiritualis

\footnotetext{
${ }^{225}$ Ms. lacte.

${ }^{226}$ Ms. exuptionem.
} 
vel ab spiritu creato vel ab increato. A creato, quia cum spiritus idem sit quod aer vel anhelitus, consuetudo ecclesiae est invisibilia et ea quae sunt a sensibus remota vocare spiritualia; dicitur etiam spiritualis sensus ab spiritu increato quia ille sensus per Spiritum Sanctum in nova lege revelatus est, ut inquit Apostolus 2. ad Cor. 3.: Epistola estis Christi ministrata a vobis et scripta non atramento sed spiritu Dei vivi. Et 1. ad Cor. 2. Nobis autem revelavit Deus per spiritum suum. Ecce quomodo scriptura constat ex sensu litterali et spirituali sicut horno ex corpore et anima. Unde Cyrillus in prologo super Leviticum quod alii ascribunt Origeni. Sicut verbum Dei (inquit) [fol. 244r] cum vestitum processit in hunc mundum et illud quidem erat quod videbatur in eo, illud quod intelligebatur, ita etiam per prophetas verbum Dei profertur ad homines litterae velamine tectum, ut litera quidem aspiciatur tanquam caro, latens vero intrinsecus spiritualis sensus tanquam divinitas sentiatur.

[R.c.12] [ $2^{\mathrm{a}}$ quaestio.] Superest nunc videre quae fuit antiqua illa divisio sensus spiritualis in sensum anagogicum et moralem. Nam sunt quídam latissimi theologi qui dicunt nec Origenem nec Hieronymum cognovisse sensum anagogicum nec moralem. Miror tamen, cum sint alias diligentissimi, hoc non invenisse apud illos. Expresse enim Origenes libro $4^{\circ}$. periarchon cap. $2^{\circ}$ distinguit triplicem sensum scripturae, scilicet litteralem, moralem seu tropologicum et allegoricum, et citat illud Proverb. 22. Tamen, aut describit ${ }^{227}$ ea tripliciter in consilio et scientia, et adducit simile ab homine qui constat ex corpore et anima et spiritu. Anima enim dicitur a spiritu saltem ratione. Nam anima dicit actum corporis. Spiritus autem dicit animam in quantum elevatur supra corpus nec dependet a corpore. Ita corpus scripturae (inquit) est sensus litteralis et anima est sensus moralis, et spiritus sensus allegoricus. A quo desumpsit eandem divisionem Eucherius episcopus lugdunensis antiquissimus in praefatione sui libri de formulis spiritualibus. Et idem Origenes homilia 2. super Genesim cap. 7. arca Noe exponit tripliciter literaliter et postea allegorice de Christo, qui fabricavit arcam in cruce qua nos redemit, et moraliter de anima cuiuscumque paenitentiis, qui indundantibus vitiis convertit se ad cor et fabricat arcam in qua salvetur secundum longitudinem, latitudinem et profunditatem vel profunde, hoc est secundum fidem, spem et charitatem.

[R.c.13] Et Hieronymus super Ezechiel cap. 16. et idem eosdem tres sensus scripturae distinguit. Et idem repetit in epistola ad Edibiam q. 12., et citat eadem verba Proverb. 22., et fundat eundem triplicem sensum in apostolo, ut sensus litteralis sit ille 1. ad Cor. 10. Nec fornicemur sicut quidam eorum fornicati sunt; et secundum tropologiam, sensum moralem illud ad

${ }^{227}$ Ms. describe. 
Cor. 9. Non alligabis os bovis ${ }^{228}$ triturantis; et secundum allegoriam, illud ad Ephe. 5. dictum de Eva. Propter hanc relinquet homo patrem et matrem, et adhaerebit uxori suae; sacramentum hoc magnum est. Non ergo est tam nova ista disputatio trium sensuum ${ }^{229}$ quam isti putant, sed verum est quod apud Hieronymus non invenio distinctum sensum allegoricum ab anagogico, sed forte primus auctor illius fuit Augustinus primo super Genesim ad litteram ca. $1^{\circ}$. In libris omnibus autem sanctis intueri oportet quae ibi aeterna intimentur quantum ad sensum anagogicum quae facta nascentur ${ }^{230}$ quantum ad litteram, quae futura pronuntientur quantum allegoricum quae agenda praecipiantur vel moveantur quantum ad moralem. Inde divus Thomas et ceteri desumpserunt illum quadruplicem sensum scripturae de nominibus horum sensuum, quae fuit $2^{\mathrm{a}}$ pars huius quaestiunculae. Iam diximus quod omnes promiscue dicuntur spirituales.

[R.c.14] $2^{\circ}$. dicuntur mystici. Quod non tractatum est etiam et desumptum ex apostolo, tum alias tum maxime 1. ad Cor. 2. Sapientiam (inquit) loquimur inter perfectos, sapientiam vera non huius [fol. 244v] seculi sed loquimur Dei sapientiam in mysterio quae abscondita est. Dicitur ergo sensus mysticus quia absconditus, et tractus a gentilibus quibus solemne erat sacra quae in templis eorum fiebant non prophanare aut vulgare sed servare in secreto, et inde dicta sunt mystica ut aliqui volunt a quod est scelus, quasi scelus esset illa revelare. Sed quod ego credo non dicitur mysticum nec a quod est occulto, sed a quod est sermo; id est occulte et in secreto servatum. Nam littera $m$, quae maxime inter mutas pressis labiis profertur, fit quod est occulto et sacris mystico, quia sacra occulte fiebant. Et inde sensus mysticus; id est reconditus.

[R.c.15] Omnes etiam mystici sensus generaliter vocantur allegorici ut notat s. Thomas ad Gala. $4^{\circ}$, sed abusive, ut dicit Chrisostomus in eodem loco, nam allegoria solum est in significatione verborum. Dicitur enim non a goge quod est dictio; sed ab, quod est aliud dico quam sentio; et sic allegoria, id est alieniloquium, est figurata locutio, ut dicit Augustinus 3. De doctrina christiana cap. 11., ut illud Matth. 3. cuius ventilabrum in manu sua et permundavit aream suam; itaque allegoria proprie est translatio verborum sed abusive accipitur per signa quae res significant alias res. Unde Augustinus ut videbimus in conclusione $4^{\mathrm{a}}$, distinguit inter allegoriam dicti et allegoriam facti, sed tamen nomen generaliter allegorice accommodatum est iam ad speciem quam res gesta veteris legis significat aliquid futurum in ecclesia militante. Nam si significat aliquid pertinens ad mores dicitur tropologia

\footnotetext{
${ }^{228}$ Ms. bovi.

${ }^{229}$ Ms. sensum.

${ }^{230}$ Ms. nacentur.
} 
as, quod est mos et significat aliquid pertinens ad ecclesiam triumphantem. Dicitur, quod est sermo supernis.

[R.c.16] Ex his sequitur tandem intellectio verborum Augustini in imperfecto super Gen. cap. 2. et de utilitate credendi cap. 2. ubi dicit quod scriptura quadrifariam traditur, scilicet secundum historiam, secundum ethimologiam, secundum analogiam et secundum allegoriam. Non enim asignat illic 4or. sensus distinctos, sed dicit quod declaratur 4or. modis, scilicet secundum historiam quando docetur quid scriptum sit, secundum analogiam cum ostenditur qua de causa factum sit. Ubi aliqui codices male habent ethimologiam, ut legit s. Thomas et modemi; sed legendum est ethiologiams, quod est causa secundum analogiam. Cum demonstratur non sibi adversari duo loca scripturae, ubi aliqui male legunt anagogia pro analogía secundum allegoriam, cum docetur scripturam non ad litteram, sed figurative esse intelligendum. Tres ergo primi modi pertinent ad sensum litteralem et ultimus ad sensum spiritualem. Haec de prima quaestione.

[R.c.17] Altera quaestio est qua necessitate aut commoditate sacra scriptura utitur metaphorice in sensu literali et praeterea rebus ipsis utitur spiritualiter ad significandum alias res. Et in utroque sensu arguitur ad partem negativam. Primo, quod non debeat uti rebus ad significandum. Arguitur quod hoc non fuerit condecens sapientiae divinae. Voces, ut auctor est Aristoteles primo peri hermeneias ${ }^{231}$, suapte natura natae sunt significare res seu rerum conceptus, quorum vicem gerunt litterae. In hoc enim solum natura se, at voces ut usui nobis essent ad exponendum conceptus. Et ab eodem usu ab hominibus institutae sunt litterae tanquam signa permanentia transeuntium vocum, ut tradit Augustinus 2. de doctrina christiana cap. 4. Res autem non sunt a natura in hoc productae ut significant. Ergo, cum Deus [fol. 245r] naturae institutor, debuit vocibus et litteris uti ad significandum et non rebus. Praeterea Deus qui suaviter disponit omnia, perspicue et lucide loqui quo imbecilles homines facilius intelligeremus et maxime cum sapientia ipsa divina, Ecclesiastes 2., elucidantibus se pollicetur vitam aetemam.

[R.c.18] Res autem non sunt perspicua signa sed amphibologica et enigmatica, v. g. transitus ille Israel de Aegypto, quod mare et sub nube symbolum erat nostri baptismi ubi peccata veluti Aegypti sumerguntur. Potuit hoc tamen manifestis verbis propheticis praedici. Et hoc quidem argumento suadetur etiam quod in sensu litterali non debuit scriptura tradi sub verbis obscuris et metaphoricis quae potius sunt ad decipiendum quam ad docendum. Et postremo arguitur. Quaecumque scripta sunt, ait Paulus ad Roma. 15., ad nostram doctrinam scripta sunt, id est ad corroborandum fidem nostram. Sed

${ }^{231}$ Ms. periarmenias. 
ut auctor est Augustinus ad Vincentium donatistam epistola 48., et q. 6. Latius manifestabimus, ex sensu mystico non sumitur efficax argumentum quod facit fidem. Ergo sensus spiritualis supervacaneus est.

[R.c.19] Duplex est ista conclusio, ut diximus. Et quare non solum verbis sed rebus ipsis usus fuerit Deus tanquam signis aliarum rerum quod pertinet ad sensum mysticum et spiritualem, et quare in sensu litterali utatur verbis metaphoricis et improprie significantibus. Nam ex utriusque ignorantia fuerunt haereses in ecclesia. In exordio enim statim nascentis ecclesiae nonnulli conversi ex gentibus non intelligentes praecepta iudicialia et caerimonias veteris legis fuisse figuram novae legis negaverunt vetus testamentum fuisse revelatum a Deo sicut cerdoniani et severinni et postea Manichaeus. Nam si quis legem illam non intelligat spiritualiter, plurimum videtur ridicula et modus edendi agnum paschale, tanta sacrificatio animalium et aspersio sanguinis et lex de mundandis leprosis et alia id genus. Ob idque Augustinus contra Faustum negantem vetus testamentum esse a Deo, illo potissimo argumento utitur, quia non ad litteram est tota intelligenda sed et plurimum spiritualiter.

[R.c.20] Alii haeretici concedentes quod res illae erant figurae novae legis negabant tamen quod $^{232}$ verba in scriptura debeant accipi metaphorice, saltem quod quam maxime fieri posset deberent accipi secundum propriam significationem, unde donatistae ut refert Augustinus epistola 48. Ad Vincentium illud Cant. $1^{\circ}$. indica mihi ubi pascas ${ }^{233}$, ubi cubes in meridie, intelligebant ad litteram de se ipsis, quod cum essent in regione meridionali, dicebant se solos pertinere ad veram ecclesiam Christi. Et alii, quia legebant hominem esse factum ad imaginem Dei, tenebant Deum habere effigiem humanam, praesertim cum scriptura humana membra, ut oculos et manus, attribuat Deo. Qui dicti sunt anthropomorphitae ${ }^{234}$, id est Deum hominem fingentes. Immo fertur modo esse Christianos qui cum baptizarentur frontem incinunt candenti ferro cum de Christo dixerit Ioannes, Matth. 3., quod esset baptizatus Spiritu Sancto et igne.

[R.c.21] Et multi alii haeretici pulularunt in ecclesia eo quod sensum litteralem solum censebant secundum propriam significationem verum, non recipientes metaphoras. Nec solum haeretici, immo etiam catholici multi in hoc fuerunt decepti, ut refert Hieronymus et super Hieremiam c. 19. et super Ezechielem c. 36., ut Papias discipulus Ioannis illud Apocalypsis 21. Vidi sanctam [fol. 245v] civitatem Hierusalem novam descendentem de caelo a Deo paratam, iuxta propriam significationem sine metaphora intelligebat. Quare

\footnotetext{
${ }^{232}$ Ms. in; pero sobra. Se repite casa a continuación.

${ }^{233}$ Ms. paseas.

${ }^{234}$ Ms. athropomorphitae.
} 
asseruit Christus adhuc venturum ad regnandum mille annos cum christianis in Hierusalem in vita felicissima, quem postea secutus est Tertulianus in libro de spe fidelium, et Lactantius libro 7., et ex graecis Victorinus et Severus.

[R.c.22] Opere pretium ergo erit adnotare quare scriptura his metaphoris et sensibus utatur spiritualibus. Et quidem quantum ad metaphoras et similitudines quae pertinent ad sensum spiritualem facile est assignare rationem. Nam illud non est proprium et peculiare sacrae scripturae, sed est commune ómnibus scientiis et maxime oratoribus atque poetis. Est enim metaphora, ut docet Quintilianus cap. 6., ubi eleganter disserit de metaphoris. Est, inquit, metaphora cum ita ab ipsa natura nobis concessa ut indocti quoque ea frequenter utantur tum ea iocunda atque nitida, ut in oratione proprio lumine eluceat, et utimur illa triplici de causa, aut quia necesse est, aut quia significantius, aut quia decentius per metaphoram explanamos effectus. Non enim potuit Petrus tam significanter ferocitatem et aviditatem daemonis exprimere si vocasset ferocem quam vocando eum leonem qui rugiens circuit quaerens quem devoret. Tamen si illa non est metaphora sed similitudo, nec Ioannes potuit exprimere multis verbis venenum pharisaeorum tam perspicue quam per illam metaphoram vocando illos progenies viperarum. Nec Christus, si propriis verbis dixisset omnem virtutem hominum in ecclesia derivari ab illo, tam perspicue rem exprimeret quam per metaphoram: Ego sum vitis vera et vos palmites. Quam allegoriam prosequitur Paulus ad Roma. 11. vocando gentes oleastrum quae loco iudaeorum infert, sunt arbori cum iudaei tanquam rami fuerint de trunco abscisi.

[R.c.23] Et eadem est ratio similitudinum quibus regnum caelorum comparatur thesauro abscondito in agro et margaritae inventae a negotiatore et his similibus. Et eadem est locutionum per parabolas. Nam ut ceteras omittamus, non posset Christus illis propriis verbis significantius exprimere quam benigne et clementer suscipiat peccatorem conversum ad paenitentiam quam per parabolam de filio prodigo. Etenim, ut ait lyricus: Segninus, irritant animas demissa per aurem quam quae sunt oculis subiecta fidelibus. Nam, cum cognitio incipiat a sensu, et ut auctor est Aristoteles primo metaphysicae, visus fuit praestantissimus sensuum, illi enim quae nobis velut in pictura quaedam ob occulos obiiciuntur et magis nos delectant et movent vehementius. Et haec est potissima ratio quare Deus per metaphoras et similitudines rerum corporalium nobis loquitur in scriptura de rebus spiritualibus. Et hanc rationem insinuat Augustinus ad Januarium de moribus Ecclesiae epistola 19. Allegoriarum scripturae, quia plus, inquit, movent et accedunt amorem allegoriae quasi nuda et sine illis sacramentorum similitudinibus ponerentur.

[R.c.24] Adde quod cum homo sit naturae rationalis, ipsa ratiocinatione et discursu a corporalibus ad spiritualia vegetatur et recreatur, ut illic insinuat 
etiam Augustinus et $2^{\mathrm{a}}$ de doctrina christiana c. 6. Dicit quod provissum est divinitus ut sub caligine et obscuritate fuerit tradita sacra scriptura ad edomandam labore superbiam, quia facile [fol. 246r] investigata plerumque vilescunt, sed quae cum aliqua difficultate quaesita sunt, multo magis gravius inveniantur et vehementius movent. Et adducit exemplum, ut si quis verbis simplicibus predicaret quemadmodum boni fideles deponentes onera et curas seculares ad sanctum baptisrni lavacrum veniunt et postea ascendentes de baptismo dant fructum genuinae charitatis Dei et proximi, non tantum delectabit et movebit aninum quam si per allegoriam quam scribitur Canti. $4^{\circ}$. Illud enunciaverit ubi ecclesiae fidelibus ait sponsus: Dentes tui sicut grex tonsarum ascendens de lavacro, quae ornnes genuinos creant et non sterilis in eis. Illa enim similitudo omnium innocentium tonsurarum sine velleribus baptizatos innocentes velut in pictura quadam representant. Haec sunt rationes allegoricorum verborum quae pertinent ad sensum litteralem.

[R.c.25] Sed maius dubium est quare Deus in scriptura non solum verba sed res ipsas instituerit ad significandum in sensu spirituali. Et circa hoc est $3^{\mathrm{a}}$ quaestio nostra, utrum hoc sit proprium sacrae scripturae. Nam ceteris scientiis commune est uti metaphoris et allegoriis. Sed uti rebus ad significandum dicunt omnes theologi, hoc est proprium sacrae scripturae solius. Nam in aliis scientiis non distinguitur sensus litteralis et spritualis, et rationem assignat $\mathrm{s}$. Thomas 1.p. q. 1. ar. 10. et quodlibeto 7. q. 6. quaestiuncula prima. Deus qui est proprius auctor sacrae scripturae est etiam conditor rerum naturalium et composuit ${ }^{235}$ non solum verba sed etiam res ipsas instituere ad significandum. Arguitur autem quod hoc non sit proprium sacrae scripturae sed conveniat etiam aliis scientiis prophanis.

[R.c.26] Hoc fuit solemne apud priscos aegyptios ut mysteria sapientiae non litteris communibus vulgarent sed quibusdam rerum similitudinibus et figuris animalium sub mysterio designabant quo essent in maiori extimatione et praeter alios Macrobius libro $1^{\circ}$. satur. refert. Nam anni circulum exprimerent effingebant serpentem, ita circumvolutum ut caudam ori teneret insertam. Ita enim annus vicibus temporum in se reciprocantibus currit. Et graeci sententiam illam, quod est festina lente exprimunt delphino circumvoluto circa ancoram $^{236}$. Nam ancora quae navim moratur significat naturae consulendum antequam opus agredieris; delphinum vero praenitissimum animal significat post deliberationem citissime operandum. Et circulus significat hoc esse observandum semper. Et Augustinus li. 3. De doctrina christiana c. 7. dicit gentiles usos esse hoc modo philosophandi ut per res significarent alias res ut

\footnotetext{
${ }^{235}$ Ms. compotuit.

${ }^{236}$ Ms. anchoram.
} 
referunt ${ }^{237}$ Claudiani carmina de Neptuno qui ita depingebatur ut proligitate comae, barbae et eorum caniciae occeani fluctus et fluminum referet: $\mathrm{Tu}$, Neptune pater, cui tempora cana crepanti cincta salo resonant, magnus cui perpete mento profluit Occeanus, et flumina crinibus errant.

[R.c.27] Et in poetarum comoediis per res quae illic geruntur notantur mores hominum, ut in Davo subnotatur versutia et astutia servorum. In Taide $^{238}$ referuntur meretricium illecebrae quibus deludere solent homines. Et Menedemus nimium amorem partum designat. Unde Plutarcus in illo opere cui Tertulianus quomodo oporteat audire poemata, multas allegorias poetarum exponit moraliter. lmmo sunt quod omnes metamorphoses Ovidii per allegoriam rerum exponantur. $\mathrm{Nec}$ ab re protrahi ${ }^{239}$ fabula ad inconstantes aptari vel accommodari potest et phaethontis ${ }^{240}$ ad temerarios. Et postremo arguitur. Daemones res etiam instituunt ad significandum quibus hornines deludant, ut est videre cum [fol.246v] apud alios tum apud Ciceronem in libro de divinitate et de fato $^{241}$. Nam in exteris animalium gentiles coniectabantur futura. Et apud Livium vultures duodecim decreverunt imperium Romulo atque alia augura innumera et portenta sunt inventa, et ab aliis et a Numa Pompilio. Ex quibus constat daemones rebus ipsis futura praedicere.

[R.c.28] Quid ergo volunt dicere theologi quando asserunt hoc ese proprium sacrae scripturae ut res aliae sint aliarum figurae? Ad haec respondetur cum s. Thoma quodlibeto 6. q. 7. ar. ultimo quod hoc est proprium sacrae scripturae quod res cursum suum naturalem peragentes; id est quando primo productae sunt in rerum natura vel quando historia serio gesta est propter necessitatem humanam vel alium verum finem, tunc productae et gestae sunt intentione significandi alias res. In aliis vera scientiis res naturales quae non sunt factae ad significandum imponuntur ad significandum vel confinguntur aliquae res quae non vere contingerunt ${ }^{242}$ ad significandum, v. g. manna descendens de caelo et aqua fluens de petra et tota historia exitus Israel de Aegypto; in sua prima conditione facta sunt ad significandum, sed homines imponunt serpentem vel alia animalia ad significandum, quae in sua naturali conditione non sunt facta ad hoc et fingunt comedias quae non sunt historiae et daemones fingunt signa quae plurimum falsa sunt, et ideo res illae confictae ad significandum sicut

\footnotetext{
${ }^{237}$ Ms. refert.

${ }^{238} \mathrm{Ms}$. Thayde.

${ }^{239}$ Ms. prothrait.

${ }^{240}$ Ms. fhaetontis.

${ }^{241}$ Ms. fhaetontis.

${ }^{242}$ Ms. facto.
} 
repraesentationes comediarum vicem gerunt vocis vel scripturae. Et ideo illa significatio est censenda litteralis. Et tunc convenit ratio quia Deus est rerum creator potest ipsam in sua primaeva conditione instituere ad significandum, sed qua id necessitate aut qua mediante ${ }^{243} 150$ factum est?

[R.c.29] Aliis alia forte videatur congruentior, nos autem hanc censemus potissimam rationem huius sensus spiritualis rebus significati. Credo Deo id placuisse ut fides venturi Messiae maxime commendaretur et orbi persuaderetur. Praeterea, non solum verbis voluit praedicare sed rebus et praefigurare. Nam si solis verbis significabatur et maxime solemnitatibus, sacrificiis et caerimoniis in quibus totus populus quotidie versabatur, non poterant hanc fidem ignorare et hac de causa promissi sunt hebraei in Aegypto tam gravia et dura pati ut beneficium ${ }^{244}$ liberationis quod erat figura Christi esset illis in memoriam sempitemam, unde Exod. 12, erit verbum istud; id est miraculum exitus de Aegypto erit (inquit) legitimum tibi et filiis tuis neque in aetemum, et cum dixerint vobis filii vestri, quae est ista religio? Dicetis eis: Victima transitus Domini est quando transivit per domos Israel in Aegypto percutiens aegyptios.

[R.c.30] Quorsum tanta commendatio beneficii nisi ut altius descenderet in corda eorum figura illa venturi Messiae? Et quanquam populus ille nondum intellexit mysteria, nobis tamen sunt maxima argumenta ad corroborandum fidem quae tantis operibus est praefigurata. Et hac ratione apostoli et ipse redemptor noster adducebant opera et caerimonias legis tanquam figuram evangelii. Altera ratio est ut mysteria fidei non essent omnibus vulgata, nam si nudis verbis essent tradita potuissent irrisioni esse vulgari plebi et incredulae. Ob id enim Deus non revelavit fidem venturi Messiae statim universo orbi, sed aggregavit fidelissimum Abraham cui proprie velut in secreto commisit et confidit illam fidem quam proinde in mysterio fidelibus suis voluit revelare quousque hominibus fide assumctis ${ }^{245}$ palam per Christum revelaretur. Et eodem modo instituit Christus postea apostolos Matth. 7. Nolite sanctam dare canibus nec mittatis [fol. 247r] margaritas vestras porcis, vel ante porcos, ne forte conculcent eas pedibus suis. Et Matth. 13., quaerentibus discipulis quare in parabolis loqueretur populo, respondit quia vobis datum est nosse mysterium Dei; id est regni, ceteris autem in parabolis ut videntes non videant.

[R.c.31] Ecce quomodo proprium est sacrae scripturae uti sensibus spiritualibus et quare placuit Deo. Et omnia quae dicta sunt adnotantur in verbis

\footnotetext{
${ }^{243}$ Ms. mediate.

${ }^{244}$ Ms. veneficium.

${ }^{245}$ Ms. assuctis.
} 
assumpti prothematis, ut tandem illud attingamus. Vidi (inquit Ioannes) ${ }^{246}$ in dextera Dei sedentis. Dextera Dei attribuit Filio cui attribuit ut sit principium et ars qui omnia facit, et illic est liber scripturae sacrae quia illi attribuitur etiam ut sit sapientia Patris. Et est scriptus intus et foris. Foris quantum ad sensum litteralem, intus quantum ad spiritualem. Nam quamquam aliae sunt expositiones etiam horum verborum, ut puta quod sapientia Dei eliciatur foris scripta propter scientiam praedictam qua se extra communicat in rerum ratione, et intus in quantum ad speculativam, quae non est a dextra operativa. Et alii aliter exponunt. Tamen verus sensus est de sacra scriptura quantum ad sensum litteralem et spiritualem. Ita exponunt Hieronymus, Gregorius, et Ezehielis 2., ubi sunt fere eadem verba. Ecce manus misit ad me in qua erat involutus liber intus et foris. Et ita Augustinus homilia 4a super Apocalypsim. Liber iste est sacra scriptura duo continens testamentum, quorum novum est intra, vetus quod omnium mysteriorum plenitudinem obscuratum est, et usque ad passionem et resurrectionem Christi mansit signatum et illi resignatum est quemadmodum testamenta mortuorum non resignantur neque ad mortem testatorum. Et ideo Apocalypsis 3. dixit Ioannes angelo Philadelphiae qua designatur ecclesia data est clavis David quae aperit et nemo claudit, claudit et nemo aperit.

[R.c.32] Clavis David dicitur spiritus ad intelligendum prophetas. Nam nomine David per anthonomasiam omnes intelliguntur prophetae; et claudit et nemo aperit, quia nisi Deo revelante non potest haberi ille sensus; et aperit et nemo claudit, quia quod ipse revelaverit nemo potest negare. Et ita apostolus 1. ad Cor. 2., quod oculus non vidit nec auris audivit, etc., nobis autem revelavit Deus per spiritum suum; spiritus enim omnia scrutatur etiam profunda Dei. Et subiungit. Nos autem non spiritum huius mundi accepimus sed spiritum quod est ex Deo ut sciamus quae a Deo donata sunt nobis, quae et loquimur non in doctis humanae sapientiae verbis sed doctrina spiritus spiritualia spiritualibus comparantes. Animalis autem homo non percipit ea quae sunt spiritus Dei. Stultitia enim est illi et non potest intelligere quia spiritualiter examinatur. Spiritualis autem iudicat omnia et ipse a nemine iudicatur, sicut scriptum est. Quis enim cognovit sensum Domini aut quis instruxit eum? Nos autem sensum Christi habemus. In cuius figuram quando Moyses tradebat legem populo, velabat faciem ut habetur Exod. 34., quasi lex sub velamine texeret mysteria. Et illud velamen optabat David auferri dicens: Revela oculos meos et considerabo mirabilia de lege tua. Et illud velum scisum est in morte Christi, ubi patefactus est sensus spiritualis scripturae quando adimpletae sunt scripturae; id est omnes figurae. Et ita exponit idem apostolus 2. ad Cor. 3. Et haec de tertia quaestione.

${ }^{246}$ Falta en el manuscrito el cierre del paréntesis. 
[R.c.33] Quarta quaestio et praecipua est quisnam sit censendus sensus litteralis. Et quidem s. Thomas qui inter scholasticos exactissime ${ }^{247}$ locutus est de hoc paucissimis verbis dicit [fol. 247v] quod sensus litteralis est ille qui habetur per significationem qua voces significant res. Et certe apud antiquos infallibiliter habebatur pro diffinitione, sed modemi sine causa non sunt contenti hac definitione, unde Burgensis addicitione $1^{\text {a }}$ super prologum Bibliae dicit diffinitionem illam esse diminutam. Nam sunt multa loca scripturae quae secundum significationem vocum accepta rederent sensu falsum, ut patet in parabolis et metaphoris, ubi dicitur brachium Dei, digitus Dei; et ideo putat addendum esse ut sensus quispiam sit litteralis qui sit intentus ab auctore principali sacrae scripturae, qui est Deus, an vero alii.

[R.c.34] Adhuc iuniores et modeni, nec illa diffinitionem Burgensis approbant. Primum, quia Deus unico simplici actu simul intendit omnes sensus tam litterales quam spirituales, et tamen litterales non sunt spirituales. Confirmatur hoc quia Deus in figuris veteris legis principalius intendebat mysteria Christi quam sensum litteralem, tamen illi sensus mysterii non erant illic Iitterales, et ideo dicunt tandem quod sensus litteralis est quem intendit auctor scripturae, non Deus; scilicet minister homo, nempe propheta vel apostolus. Ex quo inferunt unum mirabile corollarium quod eadem auctoritas prolata a diversis auctoribus diversis locis habet diversos sensus litterales, propterea solum quod a diversis proferatur, ut illius scripturae prolatae a Moyse Exod. 12. Os non comminuetis ex eo, sensus litteralis est de agno paschali et eiusdem prolatae a Ioanne c. 19. sensus litteralis est de Christo, immo si ecclesia eandem scripturam legat in diversis celebritatibus ex hoc solum facit diversos sensus litterales, ut illud Luc. 10. Intravit Iesus in quoddam castellum, cum legitur dominica $4^{\text {a }}$ post pentecostem, habet sensum litteralem illa historia ${ }^{248}$ quae vere contingit. Et cum legitur in festo assumptionis beatae Mariae habet sensum litteralem de merito et praemio beatae Virginis. Sed quidquid sit de istis additionibus sensus litteralis, sententia mea est: sensus verus quod habetur ex verborum significatione, et re vera nihil aliud opus est addere. Has diffinitiones non aliter comprobamus quam debent diffinitiones stabiliri, scilicet ex universali modo loquendi et ex nominibus ipsis a quibus non est temere discedendum ${ }^{249}$. Nisi ratio nos compellat et certe omnes sancti aliter, diffinimus sensum litteralem nisi sensum quod habetur per litteram et hoc sonat nomen ipsum. Et sensus spiritualis est qui mystice significatur per res gestas.

\footnotetext{
${ }^{247}$ Ms. exatissime.

${ }^{248} \mathrm{Ms}$. illam historiam.

${ }^{249}$ Ms. discendendum.
} 
[R.c.35] Item arguitur quia pro eodem censetur apud doctores pervestigare sensum verum litterae et sensum litteralem, et idem est disputare quisnam sit sensus verus significatus per litteram et quisnam sit litteralis. Et confirmatur hoc quia cum diffinitio, ut dicit Aristoteles, debet esse omnino quam brevissima, satis est ad corroborandum diffinitiones istas respondere aliis. Et ideo ad dominum Burgensem et alios modernos respondemus quod cum $\mathrm{s}$. Thomas et omnes antiqui dicunt sensum literalem esse illum quae pertinet ad significationem vocuum, subintelligunt genus diffiniti, puta quod sit vox ${ }^{250}$, alias non erit literalis nec spiritualis. Solus enim sensus verus dividitur in illa duo membra, et intelligunt per significationem propriam vel metaphoricam. Nam utraque pertinet ad sensum litteralem, et in his duobus decepti sunt isti modemi. Et tunc negamus domino Burgensi quod aliquis sensus litteralis sit falsus si illa diffinitio esset tenenda. Nam quando membra secundum propriam significationem faciunt sensum falsum [fol. 148r], non est ille sensus litteralis sed metaphoricus. Tunc erit litteralis, ut illorum verborum: Ego sum vitis et vos palmites. Sensus litteralis est metaphoricus. Et sensus litteralis thematis nostri. Vidi in dextera sedendis etc., non est ille qui accipitur secundum propriam significationem sed secundum metaphoram. Fatemur eodem redire si quis dicat: sensus verus est sensus intentus a Spiritu Sancto. Nam ita est quod sensus omnis litteralis intenditur a Spiritu Sancto, sicut omnis spiritualis, sed non opus est illud addere in diffinitione.

[R.c.36] Sed quid attinet ad alios iuniores et modernos? Primo, male imponunt s. Thomae illam diffinitionem sensus litteralis quod sit ille qui intenditur a Spiritu Sancto, nam quamquam ipse dicat quod sensus litteralis intenditur a Spiritu Sancto, non intelligit quod illa sit diffinitio sensus litteralis, sed quod est communis conditio etiam sensus spiritualis. Immo expresse distinguit inter spiritualem et litteralem, quod iste signicatur per voces, ille vero per res, ob idque nulla sunt eorum argumenta. Mox arguitur contra eorum diffinitionem quod diffiniunt sensum litteralem esse quem intendit auctor secundarius, ut dicunt. Nam vel subintelligunt absolute et pro eodem modo dicerent alii subintelligere quod sensus litteralis est sensus intentus a Deo, scilicet per litteram inmediate, et sic frustra arguunt contra illos de sensu spirituali si vero intelligant absolute differentiam. Nihil valet. Nam pariter auctor secundarius propheta vel apostolus intendit sensus spirituales saltem frequenter. Quis enim dubitet quin Moyses multa mysteria futuri Messiae intellexerit quem Deus excellentissimum prophetam elegit, qui vidit ipsum facie ad faciem et evidens revelavit in secreto legem quam scripsit, et David qui dicit linguam suam tanquam calamum velociter scribentis; id est Spritus

${ }^{250}$ Ms. vocus. 
Sancti ut exponit Ambrosius. Prophetae dicebant propterea procul videntes, ut docet Augustinus 12. super Genesim ad litteram et s. Thomae 2. 2. q. 17. , et maxime de apostolis, non est dubitandum quominus intenderent sensus mysticos sicut et litterales.

[R.c.37] $2^{\circ}$ arguitur. Nihil vetat esse aliquem sensum intentum a Spiritu Sancto per litteram qui non sit intentus a propheta, et maxime in propositionibus aequivocis, ut late probat Augustinus 12. confessionum et nos videbimus in quaestione 5. de illa propositione: In principio creavit Deus caelum et terram. Nam quamquam propheta debeat intelligere quae dicit, non tamen necessarium ut penetret omnes sensus, immo 4. Reg. 20. et Esaiae 38. propheta Esaias annunciavit Ezechiae quod esset moriturus et lonas nunciavit ninivitis quod essent subvertendi, et tamen non cognoverunt quod illa esset comminatoria prophetia et quod non esset ita futurum. Tunc si est sensus intentus a Spiritu Sancto per litteram, erit talis licet non sit intentus ab auctore secundario sensu mystico. Et $3^{\circ}$ arguitur. Diffinitio debet constitui per ea quae per se conveniunt diffinito. Per se autem conveniunt scripturae sacrae ut sit a Deo revelata et intenta. Per accidens autem quod sit ab homine. Nam potuit se solo $^{251}$ sine humano ministro illam creare sicut creavit mundum. Tunc arguitur sic. Si Deus se solo illam creasset, esset a Deo intentus per litteram et alius per res. Ergo eodem modo nunc debet assignari distinctio et non respectu auctoris secundarii. Est ergo diffinitio sensus literalis. Sensus vero seu intentus a Spiritu Sancto, quod eodem recidit quod [fol. 248v] habetur per significatonem vocum.

[R.c.38] Dubium restat hic quando est propositio aequivoca quae habet plures sensus veros, an omnes sint litterales. Sed hoc examinabimus quaestione sequenti postquam quis dubitaret ${ }^{252}$ circa hanc diffinitionem, quia sunt multae propositiones falsae sensu litterali in sacra scriptura, ut illa Gene. $3^{253}$. Eritis sicut dii scientes bonum et malum, et illud Cain: Maior est iniquitas mea quam etc. et illud evangelii: In Beelzebub ${ }^{254}$ principe daemoniorum, etc. et alia id genus. Dubium hoc apud omnes recitatas opiniones erit. Dicendum ergo quod non omnis propositio quae est in bibliis est sacra scriptura, sed illa quae affirmatur ab auctore scripturae. Nam idem est propositio sacrae scripturae et propositio revelata, modo illud quod affirmat propheta vel apostolus scribens pertineat ad sensum litteralem. Moyses autem non asseruit: Eritis sicut dii,

\footnotetext{
${ }^{251}$ Ms. se soli.

${ }^{252}$ Ms. dubitare.

${ }^{253}$ Ms. 2.

${ }^{254}$ Ms. Belzebuth.
} 
sed quod serpens ${ }^{255}$ illud dixisset et ille est sensus litteralis. Et eodem modo evangelium non asseruit quod Christus in Beelzebub exiret daemonia, sed quod iudaei hoc dicebant. Quare nihil vetat propositiones illas naturaliter sumptas esse falsas, ex quo sequitur quod male modemi duplicem aut triplicem auctoritatem secundarunt ${ }^{256}$ sacrae scripturare, quod accipitur, scilicet vel pro assertore alicuius dicit sacrae scripturae vel pro actore vel compilatore. Nam assertor alicuius dicti non dicitur auctor nec secundarius. Daemonii et iudaei qui multa mendacia dicebant non sunt auctores secundarii, quia non loquebantur instinctu Spiritus Sancti, immo illius quod dicitur 4. Reg. 20. Quod Esaias dixerit Ezechiae: Morieris et non vives, auctor non est Esaias sed qui scripsit libros Regum, qui asserit hoc dixisse Esaiam. Sed hoc est potissime notandum in hac quaestione ut exemplis quisque intelligat differentiam inter sensum literalem et spiritualem. Diximus quod sensus litteralis est qui habetur per significationem litterae sive propriam sive metaphoram, et spiritualis qui habetur per significationem rerum.

[R.c.39] Ex hoc oritur dubium. Nam videtur tunc quod in multis locis non possimus distinguere inter sensum Iitteralem et spiritualem. Arguitur sic. Significatio metaphorica est quando transfertur verbum a propria significatione ad impropriam propter sirnilitudinem rerum significatarum, ut non solum leo propter sirnilitudinem fortitudinis transferatur ad significandum Christum et propter similitudinem ferocitatis ad significandum hominem vel daemonem. Metaphora enim idem est quod translatio. Arguitur sic. Quando dicitur Apocal. 5. quod vicit leo de tribu luda, dubium est in quo sensu leo significet Christum. Nam animal ipsum significat Christum, et sic videtur sensus spiritualis; et nomen etiam metaphorice significat ipsum, et sic videtur sensus literalis. Eodem modo quando dicit Christus loan, 15. Ego sum vitis vera et vos palmites, dubium est an sit sensus spiritualis propter significationem qua res significant res, an literalis propter metaphoricam significationem norninum.

[R.c.40] Hic est notandum duplicem esse allegoriam, ut auctor est Augustinus in libro de vera religione cap. 50. Primum, allegoria sermonis et allegoria facti, vel sub aliis nominibus allegoria historiae et allegoria sacramenti. Allegoria sermonis est seu vocis propter allegoria qua utuntur aliquae scientiae quae est alieniloquium vel significatio verbi per translationem. Allegoria facti est quam vocant theologi sensum allegoricum et, ut supra citavimus Chrisostomum, abusive dicitur allegoria. Nam proprie graece dicitur typus, latine figura, qua una res est figura alterius. Tunc est notanda haec regula ad cognos- [fol. 249r] cendum quando est sensus spiritualis vel quando litteralis

\footnotetext{
${ }^{255}$ Ms serpentes.

${ }^{256}$ Ms. secundarum.
} 
metaphoricus. Si verba significent res aliquas gestas quae quidem gestae sunt ad significandum alias res, sensus literalis est quo voces illas res significant. Et spiritualis quo res significant alias res.

[R.c.41] Si autem verba non accipiuntur pro rebus quas proprie significant nec significant illic aliquam rem gestam, sed verba accipiuntur pro rebus quas metaphorice significant, tunc sensus est litteralis. Et metaphoricus et nullius est illic sensus spiritualis, v. g. conceptum virginis et partum pronuntiavit Esaias c. $7{ }^{257}$ dicens: Ecce virgo concipiet et pariet filium, etc. Ille sensus est litteralis et secundum propriam significationem vocum. Quare illic nec sensus est aliquis spiritualis nec litteralis metaphoricus. Sed tamen Esaias undecimo eundem conceptum pronunciat dicens: Egredietur virga de radice Iesse et flos de radice eius ascendet. Illic non significatur aliqua res gesta. Sed verba illa virga et flos non accipiuntur principiis significantiis sed metaphoricis, puta de virgine Maria et benedicto Filio suo. Illic ergo nullus est sensus spiritualis sed est sensus talis metaphoricus.

[R.c.42] At vero Numeri 27. figuratur idem conceptus per virgam illam Aaron quae germinavit inter alias quas posuit Moyses coram Domino in tabemaculo testimonii. Illa verba accipiuntur propriis significantiis, sed res gestae significant partum virginis. Nulla est ibi ergo metaphora sed sensus est litteralis et spiritualis. Eodem modo Genesis 19. illa verba quod uxor Loth convertens se ad Sodomam versa est in statuam salis, habent sensum litteralem quo significant rem gestam, et tropologicum quo significat res gesta peccatorem recidivantem quod efficitur inutilis tamquam sal postquam evanuit, ut habetur Matth. 5. Sed verba illa Luc. 9., nemo mittens manum suam ad aratrum et respiciens retro est aptus regno caelorum, nullum habent sensum spiritualem, sed litteralem metaphoricum. Nam aratrum et respiciens retro non accipiuntur pro significatis propriis sed aratrum accipitur metaphoris pro professione evangelica qua mollitur et collitur cor eversis huiusmodi desideriis. Et respicere retro est respicere ad desideria secularia. Et per haec exempla poterit quisque de aliis iudicare. Et historia transfigurationis Domini in monte in sensu anagógico significat gloriam caelestem ubi erint in illa claritate homines veteris et novi legis. Sed quando Christus dixit ut edadis et bibatis super mensam meam in regno meo, nullus est sensus anagogicus sed metaphoricus litteralis.

[R.c.43] Sed dubium est quando verba significant res non vere gestas sed solum imaginarias, quae quidem res significant alias res, utrum erit illic distinguere sensum litteralem et spiritualem, v. g. Danielis 8. Vidit Daniel arietes illos cornua excelsa contra aquilonem et meridiem quibus bestiae non 
poterant resistere, et hircum caprarum venientem ab occidente super faciem totius terrae. Quibus animalibus significatur bellum graecorum et medorum; et postea per bella medorum et graecorum significatur bellum antichristi et eius membrorum adversus catholicos. Dubium ergo est utrum illic distinguatur sensus litteralis et spiritualis. Nihilominus enim in illo loco dicit quod illic est duplex sensus litteralis. Alter minus principalis de bello graecorum, alter principalis de bello antichristi cum ecclesia. Et tamen videtur quod sit illic unus sensus litteralis et duo spirituales. Litteralis quo nomina proprie accipiuntur pro arietibus [fol. 249v] et hirco quae in rei veritate illic visa sunt a Daniele, et unus spiritualis quo aninalia illa significabant medos et graecos, et alius quo gentes illae significabant catholicos et antechristum.

[R.c.44] Sed tamen dicimus quod illic non sunt duo sensus litterales, ut vult Nicholaus, nec duo spirituales, sed solum unus spiritualis et unus litteralis. Nam animalia illa visa in imaginatione a Daniele non fuit res gesta ad significandum bella futura sed solum fuit congesta et imaginata, et ideo totum illud pertinet ad sensum litteralem, ut dicit s. Thomas quodlibeto 7. q. 6. ar. 2. ad 1um. argumentum ita quod nomen arietis et hirci accipitur illic proprie pro suo significato, sed animalia pro ipsa visa gerunt vicem vocuum ad significandum graecos et medos, sicut diximus de repraesentatione comoediae, unde tota illa significatio est litteralis; sed gentes illae in sensu allegorico per bella quae gesserunt significabant antechristum et catholicos. Idem est dicendum de illo somnio pharaonis Gene. 4., qui vidit septem boves pulchros et 7. Spicas significantes 7. septem annos fertiles.

[R.c.45] Totum illud pertinet ad sensum litteralem quia illa non fuit historia sed est metaphora rerum. Itaque propter duo ille non est sensus spiritualis. Primo, quia illa non sunt res vere gestae significantes alias res sed imaginariae. Et $2^{\circ}$, quia non sufficit aut facit sensum spiritualem quod significent quascumque sed significent res pertinentes ad Christum vel membra eius quantum ad ecclesiam militantem vel triunphantem. Defectu ${ }^{258}$ primi illud Danielis $2^{\circ}$, quod lapis excisus de monte confregit statuam quadriformem quam viderat Nabuchodonosor in somnis licet lapis significaret Christum qui destructurus erat illas 4or. partes regnorum orbis, non tamen hoc pertinet ad sensum spiritualem. Illic enim lapis visus gerit vicem vocis sive litterae quia non est res omnino gesta sed imaginata, et ideo pertinet ad sensum litteralem. Defectu $^{259} 2 \mathrm{i}$. vestis pontificis veteris legis quae late describitur Exod. 28. Quae per lapides illos et tintinnabula aliaque preciosa ornamenta designabat 4or. elementa corporaque caelestia et sidera ad motum zodiaci ut commemorat

\footnotetext{
${ }^{258} \mathrm{Ms}$. de factu.

${ }^{259} \mathrm{Ms}$. de factu.
} 
Hieronymus ad Fabiolam, non pertinent ad sensum litteralem scripturae ut putant aliqui modemi. Nam spiritualis sensus debet sumi in ordine ad vitam spiritualem. Ab illa enim denominatur spiritualis. Nam illum sensum etiam vulgares homines intelligebant.

[R.c.46] Illarum enim significationum vestis pontificis meminit late Iosephus libro 3. antiquitatum c. 11. et postea c. 12. dicit: Splendor lapidum pontificis praefigurabat victoriam quam Deus erat consessurus pugnaturis. Lllud certe non pertinet ad sensum allegoricum. Et eodem modo notandum est circa sensum tropologicum seu moralem quod non pertinet ad illum sensum quaecumque historia quae per modum exempli alliciat nos ad operandum, ut historia pacientiae Iob non facit sensum moralem quia non est sensus spiritualis. Sensus enim spiritualis non est. Non est nisi quando res per modum signi et similitudinis ostendit illud quod contigit in moralibus sicut conversio uxoris Loth ad Sodomam significat recidivium hominis ad peccatum. Et non obstruere os bovis triturantis ut commendat, significat quomodo praelati debeant vivere stipendio sui laboris. Sed officium illud heroicum Christi qui lavit pedes discipulorum non facit sensum spiritualem sed est exemplum humilitatis ut ipse dicit, itaque exemplum differt a sensu spirituali morali quia sensus sumitur ex similitudine rerum gestarum quae significant aliquem modum morum, sive moveat ad opus [fol. 250r] sive non. Exemplum autem e converso movet ad operandum licet non sint res gestae ad significandum.

[R.c.47] Aliud dubium est de similitudinibus ad quem sensum pertinent, ut quando dicitur: Simile est regnum caelorum thesauro abscondito in agro, etc. Dicimus quod hoc pertinet ad sensum litteralem, immo illic nulla est metaphora, sed thesaurus accipitur proprie pro thesauro et sic comparatio inter ipsum et regnum caelorum. Sed quando dicit thesauricate, accipitur proprie pro cumulare merita. Similiter quando dicit Petrus adversarius, videtur diabolus tanquam lego rugiens, etc., nulla est metaphora, sed accipitur illic leo pro leone, qui comparatur ad diabolum. Sed cum dicit: Vicit leo de tribu luda, illic est metaphora. Nam leo accipitur pro Christo. Itaque similitudines non solum pertinent ad sensum litteralem, sed differunt a metaphoricis. Nam illic proprie accipiuntur nomina et cum dicitur debeatis, Sapientiae $3^{\circ}$, quod tanquam scintilae in harundineto ${ }^{260}$ discurrent, illa non est metaphora verbi, sed similitudo.

[R.c.48] Maius dubium est de parabolis, ad quem sensum pertineant. In hoc enim est maxima contentio doctorum. S. Thomas 1. p. q. 1. ar. 10. ad 2 um. Dicit quod sensus parabolicus dicitur litteralis propterea quod cum res illic non sint vere gestae, primus sensus est de rebus significatis per parabolam, et

\footnotetext{
${ }^{260}$ Ms. arundineto.
} 
quia est primus dicitur litteralis. Et modemi de hoc in casu cruciant se. Certe parum refert an dicatur spiritualis vel literalis. Debemus videre per regulam superiorem an in parabola verba accipiantur proprie pro rebus quas proprie significant. Quae quidem res significant alias res, et tunc erit sensus litteralis et spiritualis distinctus. Si autem accipiantur metaphorice pro rebus improprie significatis, erit solum sensus literalis metaphoricus. Et certe re oculatius inspecta in parabolis nullus est sensus spiritualis sed solum litteralis.

[R.c.49] Nam duo aut tria sunt genera parabolarum. Aliud est quando parabola exprirnit similitudinem, ut Matth. 20. Simile est regnum caelorum de patrefarnilias qui conduxit operarios. Illic certe nullus est sensus spiritualis quia mille sunt res gestae factae ad significandum. Sed est sensus litteralis quod consideratur secundum propriam significationem vocum. Nam accipiuntur illic verba propriis suis significatis, sed historia significata comparatur ad historiam regni caelorum, sicut in similitudine unius rei ut cum dicit Petro quod adversarius est tanquam leo rugiens, nulla est metaphora aut sensus spiritualis. Ita quando comparatur una historia ad aliam historiam, nullus est sensus spiritualis. Et de hoc dicit Augustinus quod similitudo parabolica accipienda est non ut sit sed ut esse possit. ldem enim est comparare historiam veram ad historiam sicut possibile ad possibile. Itaque aliud est res in sua propia significatione factas esse ad significandum, sicut transitus mari rubri. Aliud quod cum non sint ad hoc factae, comparatur unum ad aliud. Primum enim pertinet ad sensum spiritualem, non autem $2 u m$.

[R.c.50] Potest etiam accipi sensus parabolae ut res illae fuerint confictae ad significandum sicut comoedia, ut illud forsan Matth. 21. de ficulnea cui maledixit Christus quia non ferebat fructum. Nam ut exponunt doctores cum tune non esset tempus ut ficulnea haberet fructus, illa res fuit solum conficta ad significandum synagogam ${ }^{261}$ quae non ferebat fructum spectatum. Quare nec illud pertinebat ad sensum spiritualem licet per arborem ipsam significaretur synagoga quia non erat ficulnea creata ad significandum hoc, sed assumpta solum ad signifcandum. Et ideo ipsa res gerit locum scripturae sicut res in comoediis, et serpens circumvolutus quem supra diximus significare annum apud Aegyptios.

[R.c.51] 3um. genus est quando non exprimitur similitudo rerum sed verba accipiuntur metaphorice, ut Matth. 13.: [fol. 250v] Exiit qui seminat seminare semem suum. Non dicitur simile esse seminanti, sed ipsum seminare semen accipitur metaphorice pro praedicare verbum et ita exponit Christus quod secus viam seminatus est verbum quod auditum venit malus et rapit illud. Ecce semen metaphorice accipitur pro verbo et sic illic non est nisi sensus

${ }^{261}$ Ms. sinagogam. 
litteralis metaphoricus. Et ita in parabola zizaniorum agri dicit Christus: Qui seminat bonum semen hic est filius hominis. Ager, ait, est mundus. Quamquam in illa $2^{\mathrm{a}}$ exprimitur similitudo et per haec quae dicta sunt potest quis facile iudicare quando in similibus aut methaphoris sit sensus spiritualis, et quando literalis, v. g. cantica illa Canticorum quod doctores vocant mystica certe puto non faciunt sensum spiritualem, sed litteralem. Illic enim non narratur aliqua res gesta instituta ad significandum aliam, sed accipiuntur verba omnia metaphorice, ut illud osculetur me osculo oris sui, et meliora sunt ubera tua vino fragrantia unguentibus ${ }^{262}$ optimis, non accipiuntur propriis significatis sed osculum metaphorae accipitur pro unione verbi ad humanitatem si sequamur expositionem Bernardi, nam osculans est verbum et osculatum caro, vel osculans accipitur pro Spiritu Sancto et osculatum pro anima, et osculum pro dulcedine gratiae eodem modo in condemnando peccata.

[R.c.52] Eodem modo Apocalypsis non est scripta in sensu spirituali sed ${ }^{263}$ in sensu litterali metaphorico, nam visiones illae non significant aliquam rem gestam quae sit figura aliarum rerum sed verba accipiuntur metaphorice, ut v.g. verba prothematis nostri. Vidi in sensu litterali per metaphoram significat ${ }^{264}$ quod viderit in intellectu divino scripturam sacram duplici sensu conscriptam. Unde quando dicunt doctores quod Cantica canticorum omnia sunt mystica et Dioynsius 3. cap. ecclesiaticae hierarchiae vocat Apocalypsim mysticam revelationem, et Hieronymus dicit quod habent in ea multae intelligentiae, in his omnibus et similibus dictis sanctorum mysticus sensus non accipitur pro spirituali significato per res. Sed mysticus sensus idem est quod reconditus sub similitudinibus rerum corporalium. Sicut enim allegoricus sensus accipitur ut diximus pro allegoria sermonis et pro allegoria facti, ita et mysticus sensus accipitur pro sensu spirituali recondito in rebus vere institutis ad significandum alias res et pro literali recondido vel in metaphoris verborum vel in similitudinibus rerum corporalium.

[R.c.53] Ex omnibus his colligitur quod illa divisio 4or. sensuum scripturae non debet fieri priusquam dividatur sensus in litteralem et spiritualem, et postea spiritualis in alios tres, quia non est sensus tropologicus nec allegoricus nec anagogicus nisi prius fuerit sensus spiritualis, ut patet in exemplis superioribus. Et hoc quod dicit Augustinus 3. de doctrina christiana c. 10. et in sequentibus ut illud: Diliges Dominum Deum tuum, licet pertineat ad mores, non facit sensus moralem nec illud: Nemo mittens manum suam ad aratrum, nec illud: Egredietur virga de radice Iesse, facit sensum allegoricum

\footnotetext{
${ }^{262}$ Ms. ungentis.

${ }^{263}$ Ms. set.

${ }^{264}$ Ms. significant.
} 
sicut nec illud: Ecce virgo concipiet, nec illud: Ut edatis et bibatis ${ }^{265}$ super mensam, faciat sensum anagogicum. Alias sensus littteralis coincideret cum spirituali.

[R.c.54] Ultimum dubium principale circa quaestionem est, an omnia verba sacrae scripturae sint vera in aliquo sensu litterali, ita ut nullus sit locus qui non habeat aliquem sensum litteralem verum. Nam frequenter apud doctores antiquissimos ecclesiae legimus quod ubi deficit litera in sacra scriptura et sensus litteralis, recurrendum est ad mysticum. Et haec inter alios est frequentissima doctrina Origenis homilia $4^{\mathrm{a}}$ super Genesim Nam semper [fol. 251r] inquit in scripturis divinis historialis consequentia stare potest ut illic: Spinae nascentur in manus ebriosi. Et cum dicitur vox mallei et securis non est audita in domo Dei 3. Reg. $6 .{ }^{266}$ libro 4. periarchon c. $2^{\circ}$ probat quod in multis locis sacrae scripturae deficit sensus litteralis. Et dicit hoc factum ese providentia divina ne videntes perpetuam significationem litterae habere veritatem, putaremus non esse conscripta nisi propter litteralem sensum nec continere alia mysteria.

[R.c.55] Cum enim videmus, inquit, sensum literalem saepe deficere intelligimus sensum spiritualem principaliter esse intentum a Spiritu Sancto. Et Gregorius saepissime apud Iob 1. superdicit quod ubi deficit littera recurrendum est ad mysteria, ut libro 4. c. 3. et alibi saepe. Et frequenter hoc legimus apud doctores, et citant illud ps. 78. Comederunt Iacob et locum eius desolaverunt, quod non videtur posse habere sensum litteralem verum. Ad hanc quaestionem facile respondemus. Nullus est locus in sacra scriptura qui non habeat sensum litteralem verum vel falsum secundum propriam significationem vel secundum metaphoram. Ista ergo est manifesta, nam cum sacra scriptura vel sit historialis vel praeceptiva vel doctrinalis, necesse est quod secundum litteram contineat veritatem, alias esset fabulosa.

[R.c.56] Et confirmatur quia verba sacrae scripturae vel significant aliquam rem gestam quae instituta est ad significandum aliam sub figura, et tunc sensus litteralis est quo verba significant illam rem, aut non significant rem quae sit figura alterius, et tunc sensus litteralis est quo significant immediate in mente aliquid proprie et metaphorice, et non est dare medium si verba teneantur significative, immo est de fide quod omnia verba habeant sensum litteralem verum. Alias vel essent fabulosa et falsa, vel non acciperentur significarive. Et ideo quando dicunt doctores quod sensus litteralis est verus, intelligunt litteralem metaphoricum ut comederunt Iacob, secundum propriam significationem facit sensum falsum sed metaphorice, ut comedere accipiatur

${ }^{265}$ Ms. vibatis.

${ }^{266}$ Ms. sigue en el manuscrito un espacio en blanco. 
pro destruere et in nihilum redigere, facit sensum litteralem verum. Et hoc etiam vult dicere Origenes.

[R.c.57] Peccat tamen Origenes in hoc quod multa verba quae sunt proprie accipienda accipit metaphorice ut totam plantationem arborum paradisi negat fuisse veram historiam, sed sensum litteralem dicit fuisse metaphoricum in quo merito reprehenditur a Hieronymo in epistola ad Panachium quod per arbores intelligeret angelos et per flumina virtutes Sed in hoc etiam Ambrosius subnotatur. Nam illud quod Petrus ex frigore acceserit ad prunas ${ }^{267}$ in atrio sacerdotis exponit ad litteram per methaphoram non de frigore materiali sed de spirituali quod aliis non placet. Itaque nullus unquam fuit nisi manifeste haereticus qui negaverit totam sacram scripturam esse veram in sensu litterali. Sed tamen aliqui credunt sensum litteralem esse methaforicum ubi est verus secundum propriam significationem, ut aliqui modemi quod Eva fuit facta ex costa Adae non negant quando habeat sensum litteralem verum, dicunt tantum esse metaphoricum et quidem male et contra regulam Augustini 3. de doctrina christiana admonentis quam maxime fieri possit debere nos servare sensum litteralem in significatione propria nisi rationes nos compellant ${ }^{268}$ recurrere ad metaphoram vel ad figuram.

[R.c.58] Et tamen ut illis admonet Augustinus observandum quod figura non tollit veritatem litterae ut illud: Hoc nunc, os ex osibus meis, dictum de Eva [fol. 251v] Gene. $2^{\circ}$ et illud Gene. 3. Pulvis et in pulverem ibis. Licet videatur falsum quod Eva non erat os nec homo pulvis, est tamen in verum per synecdochem ${ }^{269}$ per quantum nomen metaphorice accipitur pro re facta ex tali materia, et illud Gene. 3. Ecce Adam quasi unus ex nobis factus est, est verum in sensu litterali per ironiam. Et illud pariter 3. Reg.18. ${ }^{270}$ quod Esaias ridens prophetas dicebat: Deus vester aut in diversorio est aut in itinere aut dormit. Sunt enim in sacra scriptura omnes figurae quae sunt in aliis scientiis. Ex quacumque ignorantia saepe exponentes allucinantur, ut illud Matth. 19. Facilius est camelum per foramen acus intrare quam divitem intrare in regnum caelorum, quod multos expositores exanciat. Certe per figuram est verum hyperbolem quod est locutio per excessum ${ }^{271}$ ad exagerandum diffinitionem rei.

[R.c.59] Etenim, quia iuvenis ille etsi a iuventute praecepta servaverat et tantam opinionem de Christo conceperat, tamen admonitus ut bona sua

\footnotetext{
${ }^{267}$ Ms. pruinas.

${ }^{268}$ Ms. compellat.

${ }^{269}$ Ms. sinedochem.

${ }^{270}$ Ms. 16.

${ }^{271}$ Ms. excosum.
} 
venderet, non potuit acquiescere, merito prorumpit Christus in hyperbolem. Nam verba Christi plus significant quam historia ipsa iuvenis: Manifestat quam difficile sit divitibus iacturam bonorum facere propter Deum. Itaque verba illa non faciunt sensum ut sit impossibile, sed ut sit difficile. Et simile est illud Luc. 10. Neminem per viam salutaveritis. Non enim prohibentur apostoli salutare obvios, sed ad exagerandum quod nihil eos demoraretur ab officio praedicationis. Per hyperbolem dictum est neminem. Et eodem modo exponit Augustinus illud Matth. 5. Non iurare omnino. Non prohibet iuramentum in omni casu ut putant aliqui haeretici. Sicut Eva quod Deus praeceperat ne comederet, ipsa per hyperbolem explicuit dicens: praecepit nobis ut ne tangeremus. Haec de $4^{\mathrm{a}}$ quaestione.

[R.c.60] Quinta quaestio fuit proposita an eadem scriptura possit habere piures sensus litterales. Et certe non erat tam difficilis quam illam. Iam faciunt nonnuli modemi. Statuunt enim in praesenti duas inter alias quaestiones. Una est nullum dictum sacrae scripturae unum numero in eodem loco ascriptum $\mathrm{ab}$ eodem auctore potest habere duos aut plures sensus litterales. Altera quaestio ${ }^{272}$. Unum dictum in spem in diversis locis sacrae scripturae eo quod est assertum ad diversis auctoribus habet diversos sensus litterales, ut illud os non comninuetis ex eo, Exod. 12., facit sensum litteralem de agno paschali, et Ioann. 19. facit sensum literalem de Christo, et ita statuunt regulam generalem quod omnia dicta veteris legis citata in novo testamento $a b$ evangelistis vel apostolis faciunt sensum literalem in novo testamento. Immo si ecclesia canit unum evangelium in una celebritate et idem in alia habet diversos sensus litterales. Atvero vel ego fallor vel sine causa asserunt dictas conclusiones, immo non ego sed omnes profecto antiqui oppositas conclusiones asserunt.

[R.c.61] Sit ergo prima conclusio propter illos contra primam. Idem dictum sacrae scripturae in eodem loco habet piures sensus litterales. Ista conclusio est Augustini 1. de doctrina c. 27. et 12. confessionum c. 20. et in sequentibus usque ad finem, ubi ipsi putant Augustinum tenere oppositam sententiam. Principaliter enim tractat illam primam conclusionem in c. primo Gene. In principio creavit Deus caelum et terram. Dicit enim quod potest habere triplicem sensum, ut prius dixerat 1. super Genesim ad litteram c. 1., secundum quod nomen principii accipitur vel principio temporis vel principio ordinis; id est ante omnes creaturas [fol. 252r] vel principio increato. Et omnes illi sunt sensus litterales, ut demonstrat s. Thomas 1. p. q. 46. et quod illa sit sententia Augustini patet. Nam tractat illic illam conclusionem, utrum quidquid vere significant illa verba intellixerit et intenderit Moyses. Et dicit cap. 23 . quod alia quaestio est de veritate verborum et alia quid Moyses

\footnotetext{
${ }^{272}$ Ms. conclusio.
} 
senserit in illis diversis verbis. Et subiungit c. 24. quod non est tam certum Moysem intellexisse omnes illos sensus quam est certum omnes re veros. Et c. 25. dicit quod stultum est in tanta copia verissimarum sententiarum quae de illis verbis erui possunt, affirmare quam earum Moyses senserit et addit quod forte Moyses omnes intellixerit et tandem ${ }^{273}$ concludit quod licet Moyses non omnes intenderit, Deus tamen omnes intendit nobis revelare.

[R.c.62] Tunc arguitur. Si Deus omnes intendit revelare per voces immediate, ergo omnes sunt litterales, sed negant isti consequenciam quia non sunt intenti a Moyse. Sed iam nos superius commostravimus quod intentio auctoris 2 . est ${ }^{274}$ de per accidens in sacra scriptura. Nam sicut prophetis ${ }^{275} 182$ non revelantur omnia mysteria, ut patet de Isaia qui non intellexit mortem Ezechiae et de Iona pronunciante subversionem ${ }^{276}$ Ninivae, et Daniele qui petebat $\mathrm{ab}$ angelo maiorem intelligentiam quam ipse habebat et non obtinuit, ita non requiritur quod auctor scripturae intendat omnes sensus quos intendit Spiritus Sanctus. Item, quia ut illic dicit Augustinus verissime est quod Moyses omnes intendit, sed in hoc isti decipiuntur quod illic dicit Augustinus c. ultimo quod si Moyses solum unum intendit, illa erit excellentior ceteris ex quo isti inferunt quod sola illa est litteralis, tamen licet dicat illam esse excellentiorem, non subinde negat alias esse litterales. Item arguitur sic. Si Deus se solo scripsisset scripturam sicut creavit mundum, omnes sensus veri inmediate significati per litteram essent litterales. Ergo.

[R.c.63] 2a. conclusio est contra 2am. istorum. Quod omne dictum sacrae scripturae quem solum litteralem habet in uno loco eundem habet in alio, saltem non mutatur per hoc quod asserat de alio auctore. Haec certe est magis manifesta conclusio quam quae indiget probatione. Accipiamus illud: Os non minuetis ex eo, vel et illud Exod. 12. Erat propheticum in sensu litterali vel in sensu spirituali? Non primum, quia erat praeceptum legale, ergo in sensu spirituali erat proheticum quo res significabant alias res, sed loannes citavit illud in sensu quo erat propheticum, alias ad quid citasset illud. Et ita dicit: Ut adimpleretur scriptura. Ergo citat illud in sensu spirituali. Et confirmatur hoc quia si sensus litteralis esset de Christo loan. 19., tunc illa verba essent aequivoca postquam diversa significant proprie in sensu literali, nisi quis dicat quod Ioannes accepit metaphorice, quod est falsissimum. Nam tunc

\footnotetext{
${ }^{273}$ Ms. tandet.

${ }^{274}$ Ms. et.

${ }^{275}$ Ms. profetis.

${ }^{276}$ Ms. subersionem.
} 
non essent ${ }^{277}$ eadem scriptura et loannes dicit: Ut adimpleatur scriptura. Sed arguitur manifeste. Nam loannes non asserit illa verba sed acccepit materialiter tanquam veteris testamenti. Ergo retinent eundem sensum.

[R.c.64] Sed quid opus est argumentis, quia Paulus expresse ad Gala. $4^{\circ}$ citat scripturam in sensu allegorico dicens: Quae sunt per allegoriam dicta. Sed illud miror quomodo isti asserant quod propterea quod ecclesia canat unum evangelium in diversis festivitatibus faciat diversos sensus litterales. Nam quod hoc evangelium cantetur nunc vel aliud, potest fieri solum auctoritae episcoporum aut praelatorum excludentium concilium et sententiae papae, qui tamen non possunt facere sensum litteralem [fol. 252v] et possunt errare in declarando quod ille sit sensus litteralis. Et est manifestum quod evangelium: Intravit Iesus in quoddam castellum, non cantatur de virgine in sensu litterali. Sed unus est error universalis et alios doctores qui maioris censentur auctoritatis decipit in hac parte. Putant enim quod ex eo quod apostoli vel evangelistae citant aliquod testimonium veteris legis, quod sensus ille in quo citant est litteralis, unde inferunt quod illud 2. Reg. 7., ego ero illi in patrem et ipse erit mihi in filium, habet duos sensus litterales. Unum de Salomone, de quo videtur illic littera loqui, et alium de Christo, quia apostolus ad Hebraeos 1. citat illud de Christo, et eodem modo illud Ps. $8^{278}$., omnia subiecisti pedibus eius, habet unum sensum literalem de homini communi et aliud de Christo. De quo citat illud apostolus ad Hebr. 2. et ad Ephe. 1.

[R.c.65] Et ratio istorum est quia si in regula Augustini ad Vincentium ex solo sensu litterali sumitur argumentum efficax, et ideo Caietanus quia non vidit quomodo illa auctoritas ad litteram intelligatur de Christo, negat quod epistola ad Hebraeos sit Pauli, quia Paulus non citasset sensum qui non est litteralis. Sed miror quanto errore isti teneantur. Nam quidquid sit de istis auctoribus, certe collectio nulla est. Paulus citat illud, ergo citavit in sensu litterali. Nam ad Gala. expresse ait et citat in sensu allegorico. Et Ioan. ut modo diximus. Immo univoce psallitur quae in antiquitate in sensu litterali significabant; id est figurabant Christum, in eodem sensu citata sunt ab evangelistis. Nam apostoli et evangelistae non citabant solum ad convincendos iudaeos sed primo ad suadendum. Nam sensus spiritualis licet non convinceret vehementer suadebat maxime apud illos qui sciebant historias suas esse figuram Messiae. Et $2^{\mathrm{a}}$ citabant propter nos credentes agnosceremus quomodo vetus lex erat figura novae.

[R.c.66] Et arguitur contra istos. Nam iudaei qui non reciperent sensum citatum ab apostolis esse spiritualem, minus reciperent esse litteralem, et

\footnotetext{
${ }^{277}$ Ms. esset.

${ }^{278}$ Ms. 9 .
} 
ideo minus. Sed ad videndum utrum illa auctoritas: Ego ero illi in patrem, habeat duplicem sensum litteralem, videndum est utrum secundum propriam significationem verborum intelligatur de Salomone et per metaphoram de Christo. Nam per regulam Lyconii eadem littera aliquando loquitur de figura, aliquando de figurato, et multa dicit illic 2. Reg. 7. quod non potuit intelligi nisi de Christo. Eodem modo illud Ps. 8. ${ }^{279}$ Quid est homo quod memor est eius, forsan ad literam intelligitur de Christo sicut totus psalmus. Nam in hoc sensu videtur illud citare Paulus. Et hoc de quinta quaestione.

[R.c.67] 6. quaestio et ultima posita fuit utrum ex solo sensu litterali sumatur efficax argumentum. Et videtur quod non. Nam sensus spiritualis est verus et intentus a Spiritu Sancto sicut litteralis. Immo in veteri lege principalius intendebat Spiritus Sanctus mysteria Christi quantum sensum litteralem. Item quia alias supervacaneus esset, sicut supra argumentabamur. Nam quaecumque scripta sunt ad nostram doctrinam scripta sunt. ad Roma. 15. Si ergo inde non sumimus argumentum ad quid valet? In contrarium est. Primo, Dionysius in epistola ad Titum. Symbolica (inquit) ${ }^{280}$ theologia; id est quae ex similitudinibus procedit, non est argumentativa. Et Hieronymus 2. libro super Matth. super illud de fermento abscondito [fol. 253r] in farinae satis tribus dicit quod sensus spiritualis est quidem prius. Sed namque parabolae et dubia enigmatum intelligentia potest ad auctoritatem dogmatum proficere. Et eadem est sententia vulgata Augustini in epistola 45. ad Vincentium.

[R.c.68] Hanc quaestionem iam non superest nobis tempus late disputandi. Ad quam perinde breviter respondemus quod ex solo sensu litterali sumitur efficax argumentum nec ex spirituali exposito in sacra scriptura, sicut est ille de filis Abrahae expositus a Paulo et os non minuetis ex eo. Et ratio quare ex spirituali non sumitur argumentum efficax, non est quia non sit verus et intentus a Spiritu Sancto, sed quia est valde enigmaticus et ambifologicus. Sumit tamen argumentum ad suadendum sicut apostoli sumebant. Et praedicatores possunt sumere dummodo sit sensus fundatus in littera, quod est accuratius notandum quam solet inter praedicatores observari.

[R.c.69] Amen. Uni trino que Domino sit sempiterna gloria. Amen. Amen.

\footnotetext{
${ }^{279}$ Ms. 5.

${ }^{280}$ En el ms. no se cierra el paréntesis tras inquit.
} 


\section{Praelectiones}

a) Ott. lat. 782

[L. a.1] [fol. 66r/295r] [...] Postquam habemus quod articuli possunt crescere successione temporis ad dirimendas novas haereses, quaeritur ad quem pertineat condere novos articulos, utrum ad summum pontificem pertineat. Et respondet s. Thornas affirmative. Et probat primo argumento sed contra: quia editio symboli facta est in concilio generali, ut patet in concilio nicaeno; sed conciliumn congregatur auctoritate papae, ut habetur per totam distinctionem 17am. Ergo.

[L.a.2] $2^{\circ}$, quia articulus fidei non est nisi quaedam determinatio quae proponitur credenda adversus aliquam haeresim; sed ad summurn pontificem spectat $^{281}$ determinatio dubiorum fidei, ut habetur 24. q. 1. c. quaeritur. Est enim mendum in litera $\mathrm{s}$. Thomae, nam in d. 42. non est tale verbum. Idem habetur et maiores de baptismo et eius effectu.

[L.a.3] Haec quaestio est gravissirna et habet difficultatem adversus haereticos et inter nonnullos catholicos. Latius nos illa tractavimus in relectione mea de auctoritate sacrae scripturae. Repetam nonnulla quae illic diximus et adiiciam alia. Primurn omnium, Wiclef sermone 45., ut refert Waldensis 1. tom. li. 2. cap. ${ }^{282}$ dicebat quod nec papa nec tota ecclesia habet auctoritatem condendi articulos fidei, nec determinandi aliquid tanquam de fide eliciendo illud ex sacra scriptura. Hoc patet, nam in concilio nicaeno determinata sunt multa de fide quae antea non erant expressae de fide tanquam articulus, sicut quod Christus est Deus consubstantialis Patri, quod beata Virgo est vere mater Dei, etc.

[L.a.4] Sed confirmatur auctoritate sacrae scripturae. Nam Mattha. 28. Ecce ego vobiscum sum usque ad consummationem saeculi. Et Ioha.14. Ego rogabo Patrem et alium Paraclyturn dabit vobis ut maneat vobiscum in aeternum. Et tamen non erat necessariurn quod Christus et Spiritus Sanctus manerent Semper in ecclesia nisi ad gubernandum ecclesiam, et potissimum ad exponendum scripturam, quam ipse Spiritus revelaverat.

[L.a.5] Et ratione probatur. Nam Christus nisi mutasset conditiones hominum tam clare et perspicue quin alii homines alios elicerent sensus ex eisdem verbis. Nam haec est conditio humana ut quot capita tot sensus, sicut

\footnotetext{
${ }^{281}$ Ms. expectat.

${ }^{282}$ En el ms. no hay número.
} 
Arius $^{283}$ ex illo verbo: Pater maior me est, elicuit Christum non esse Deum. Et Sabellius ${ }^{284}$ ex illo verbo: Ego et Pater unum sumus, elicuit Filium esse eadem persona cum Patre. Ergo necessarium fuit quod Christus relinqueret in ecclesia auctoritatem explicandi sacram scripturam, ita ut illa expositio esset de fide.

[L.a.6] Sed respondent haeretici illud non esse necessarium. Sed quando esset dubium, spectanda est revelatio a Deo inmedite. Sed arguitur quod hoc est intollerabile. Nam si emergente dubio est spectanda revelatio, vel alia revelatio debet fieri singulis personis dubitantibus vel deberet fieri uni qui enuntiaret aliis. Primum esset absurdum et fatuum dicere; puta, quod singuli qui dubitarent spectare revelationes speciales.

[L.a.7] Et si dicitur secundum, tunc est argumentum, quia vel esset certissimum et de fide quod ille cui fieret revelatio posset nos decipere vel non. Si non esset certissimum, tunc adhuc semper maneremus dubii an ille diceret nobis verum, et tunc essent schismata $^{285}$ inter homines contra praeceptum Pauli 1ae. Corinth. 1. Si autem esset de fide quod ille non potest nos decipere, certe non potest ille esse alius nisi vel papa vel concilium. Et sic non est dubitandum quin ecclesia possit determinare aliquid tamquam de fide.

[L.a.8] Sed tunc est 2 um. dubium. Quae est ista potestas ecclesiae ad condendum articulum fidei? Utrum condere articulum fidei sit recipere novam revelationem sicut apostoli vel prophetae receperunt novas revelationes scripturae canonicae? Breviter sine argumentis respondetur quod non. Nam apostoli et prophetae inmediate illuminabantur a Deo. Itaque recipiebant cognitionem interiorem inmediate a Deo. Ecclesia vero non, nec totum concilium, nec papa. Sed isto modo illuminantur quod si ecclesia consulat sacram scripturam diligenter et conferat unum locum cum alio, et utatur etiam rationibus naturalibus ad determinandum aliquid sive pertinens ad mores, sive ad fidem, non permittetur errare. Sed tamen si velit ecclesia spectare revelationem inmeditate a Deo, ut dicit Wiclef, tunc certe erraret.

[L.a.9] Sed tunc est dubium quomodo sumus certi quod non errat; puta, quod non erraverunt patres concilii nicaeni in determinationibus fidei. Forsan non egerunt totum quod in se erat, nec diligenter perscrutati [fol. 66v/295v] sunt scripturas. Respondetur quod sumus certi quod non permittet ecclesiam determinare aliquid nisi fererit quantum in se est, sufficientem diligentiam.

[L.a.10] Sed tunc est dubium quia tunc videtur quod nullam dignitatem attribuimus in hoc ecclesiae, nam nulli singulari personae facienti quod est

\footnotetext{
${ }^{283}$ Ms. Arrius.

${ }^{284}$ Ms. Sabelius.

${ }^{285}$ Ms. scismata.
} 
in se diligenter permittet errare. Respondetur hoc ese falsum; imo stat quod vetula, imo doctor theologus, faciat quantum potest et nihilominus erret licet ignorantia erit tunc invincibilis. Sed ecclesia non potest errare nec per ignorantiam invincibilem in his quae sunt fidei.

[L.a.11] Habemus ergo primum. Quod ecclesia instituere articulum non est recipere novam revelationem. Ex quo sequitur $2^{\circ}$. quod determinationes ecclesiae non sunt sacra scriptura. Hoc vero connotat sacra scriptura, quod sit inmediate revelata a Deo. Revelatio tamen ecclesiae non est inmediate a Deo, sed per sacram scripturam. Et ideo revelatio apostolorum, puta sacra scritura se habet sicut principium respectu revelationis ecclesiae.

[L.a.12] [Lectio 12 ${ }^{\mathrm{a}}$ ] Aliud dubium principale sequitur hic. Utrum sit tanta auctoritas ecclesiae sicut sacrae scripturae. Auctoritas enim sacrae scripturae, ut diximus, modo est auctoritas apostolorum qui loquebantur ex revelatione Dei inmediata. Auctoritas ecclesiae est fundata etiam in revelatione Dei sed mediante scriptura. De hoc etiam diximus in eadem relectione. Sunt circa hoc 3. opiniones. Prima est Abulensis in sua introductione super Matthaeum q. 13., ubi dicit quod ecclesia est maioris auctoritatis quam evangelistae et quam mille evangelistae. Et probat quia propter quod unumquodque tale et illud magis. Sed evangelistis non credimus nisi propter ecclesiam, quia praecepit ut credamus illis. Ergo maioris auctoritatis est ecclesia. Et confirmatur auctoritate Augustini contra epistolam fundamenti Manichaei cap. 5. Evangelio non crederem nisi ecclesiae auctoritas me compelleret.

[L.a.13] Alia est opinio in alio extremo, quae est Caietani de auctoritate papae et concilii cap. 4. Dicit enim quod maior est auctoritas Ioannis evangelistae quam papae et totius ecclesiae. $3^{\text {a }}$ opinio est media Ioannis Driedo libro 4. de ecclesiaticis cap. 4. distinguens de ecclesia. Dicit enim quod si ecclesia accipiatur pro tota ecclesia a tempore apostolorum includendo ipsos apostolos, tunc ecclesia et scripturae eiusdem auctoritatis sunt in his quae sunt fidei, nam eadem est veracitas. Hoc patet manifeste quia soli apostoli habent tantam auctoritatem sicut scriptura; imo, est eadem omnino auctoritas, nam scriptura est assertio apostolorum.

[L.a.14] Alio modo accipitur ecclesia pro tota ecclesia excludendo apostolos. Et sic non est tantae auctoritatis sicut scriptura, nec sicut ecclesia primo modo. Hoc patet quia ecclesia isto modo non potest condere scripturam sacram sicut apostoli, quia non recipit inmediatam revelationem sicut ipsi; imo, non potest aliquid determinare tanquam de fide nisi quatenus elicitur ex dictis apostolorum.

[L.a.15] Et eadem est sententia Durandi 3. d. 24. q. 1. Dicit enim quod ecclesia quae modo est non est tantae auctoritatis sicut antiqua ecclesia. Et ita Durandus et Driedo intelligunt illud Augustini: evangelio non crederem, 
etc., de ecclesia quae modo est, sed de ecclesia apostolorum. Itaque insinuant quod ecclesia quae modo est non sufficeret determinare aliquam esse sacram scripturam.

[L.a.16] Et idem videtur praetendere dominus Waldensis tomo 1. li. 2. cap. 22; imo dicit quod sunt aequalis auctoritatis; imo, dicit unum mirabile. Quod ecclesia quae modo est non posset augere nec explicare plures articulos fidei, quia iam omnes sunt expliciti, sicut homo qui pervenit ad perfectam aetatem non posset amplius crescere. Nihilominus, quia quaestio haec est valde necessaria et pro isto articulo et pro quaestione 6 . ubi dicturi sumus de causa fidei, respondeo hic per aliquas propositiones.

[L.a.17] Prima. Comparando apostolos ad sacram scripturam quantum ad auctoritatem, ut comparat Driedo, nulla est comparatio; id est, nihil est dicere quod sint aequalis auctoritatis. Nam eadem est omnino auctoritas apostolorum et sacrae scripturae, sicut eadem est auctoritas alicuius hominis et assertionis suae. Nam scriptura est assertio apostolorum, nec scriptura habet auctoritatem nisi quam habent apostoli in quantum apostoli. Poterat enim apostolus errare, quia poterat peccare venialiter, ut forsan peccavit Petrus in observatione legalium.

[L.a.18] Sed in quantum conditores scripturae non poterant errare. Et ideo quando comparamus ecclesiam ad sacram scripturam non habemus in ecclesia includere apostolos. Imo idem est comparare ecclesiam ad sacram scripturam et comparare ad apostolos. Sed debet accipi ecclesia seclusis apostolis pro ecclesia quae non potest condere scripturam. Diximus quod soli apostoli per inmediatam revelationem possunt condere scripturam. Sed ecclesia seclusis apostolis, quia non recipit inmediate revelationem, non potest condere scripturam, sed potest determinare articulos quatenus sequuntur ex sacra scriptura. Et de auctoritate huius ecclesiae loquimur.

[L.a.19] $2^{\mathrm{a}}$ conclusio. Accipiendo ecclesiam isto modo seclusis apostolis, non potest sustineri opinio [fol. 67r/296r] Abulensis; vilelicet, quod ecclesia sit maioris auctoritatis quam evangelista. Videtur enim quod Abulensis accipiat ecclesiam ut distinguatur contra apostolos postquam comparat illam ad evangelistas. Nam auctoritas apostolorum est auctoritas divina. Et scriptura sacra quae est assertio apostolorum, est asssertio ipsisus Dei. Quare illa est summa auctoritas. Imo, nec Deus est maioiris auctoritatis quam ipsa scriptura.

[L.a.20] Et hoc significat redemptor noster Matth. 24. Caelum et terra transibunt, verba autem mea non transibunt. Comparavit auctoritatem scripturae rebus firmissimis quae sunt in universo. 1. Tess. 2. Accepistis non verbum hominis, sed ut vere est. Et Gal. 1. Si nos aut angelus de caelo evangelizet vobis praeterquam quod evangelizaverimus vobis, anathema sit. Quasi dicat: si nos ipsi apostoli et omnes angeli de caelo et a fortiori 
totus mundus dixerit oppositum illius quod nos praedicamus, non debemus credere.

[L.a.21] Unde ad argumentum Abulensis respondemus quod evangelistae non habent auctoritatem ab ecclesia sed a Deo. Nec credimus illis quia ecclesia praecipit, sed quia Deus praecipit. Et ad argumentum: si ecclesia non diceret hoc esse evangelium Iohannis vel Matthaei, ego non crederem dictis evangelistae; ergo auctoritas evangelistarum est ab ecclesia, concesso antecedenti negamus consequentiam. Volo dicere quod ecclesia solum est causa quia ego credam haec esse dicta evangelistae. Sed postquam credo quod iste est evangelista, non credo dictis eius quia praecipit ecclesia, sed ex habitu inclinor ad assentiendum dictis eius tamquam dictis Dei.

[L.a.22] Itaque si postquam credo quod iste est evangelista, non credo dictis eius quia praecipit ecclesia, sed ex habitu fidei inclinor ad assentiendum dictis eius tamquam dictis Dei; itaque si postquam ego credidi quod haec sunt verba Iohannis, praeciperet ecclesia per impossibile quod Verbum non ${ }^{286}$ caro factum est, nullo modo obedirem ecclesiae, sed crederem Iohanni. Exemplum, sicut si esset papa coram me quem ego non cognosco, et quidam homo plebeius diceret mihi: Hic est papa Paulus, postea non crederem dictis papae propter illum plebeium hominem, sed propter auctoritatem papae licet crederem hunc ese papam propter illum hominem. Et hic est sensus auctoritatis Augustini:evangelio non crederem, etc.; id est, non crederem evangelio nisi ecclesia diceret hoc esse evangelium. Sed inde non sequitur quod auctoritas evangelistae vel scripturae sit ab ecclesia.

[L.a.23] Sed dubium est e converso, utrum scriptura vel apostoli sint maioris auctoritatis quam ecclesia seclusis apostolis, ut vult dominus Caietanus. Sit $3^{\mathrm{a}}$ propositio quod auctoritas utraque est divina licet auctoritas scripturae et apostolorum sit inmediatior quam auctoritas ecclesiae, nam ecclesia in determinationibus fidei inititur sacra scriptura et auctoritate apostolorum.

[L.a.24] $4^{\mathrm{a}}$ conclusio. Eadem species haeresi esset negare auctoritatem ecclesiae quae nunc est et concilii legitime congregati et negare propositionem evangelii. Probatur quia etiam illud quod concilium determinaret esset revelatio divina licet mediata. Idem enim est quod Deus per apostolos inmediate revelet scripturam et per scripturam revelet concilio explicationem alicuius articuli licet gravius peccatum esset in eadem specie negare propositionem evangelii aut Pauli.

[L.a.25] $5^{\text {a287 }}$ connlusio. Aliquo modo posset dici maior auctoritas scripturae quam ecclesiae; id est, inmediatior. Sic dicit Aristoteles 1. post. Quod credimus magis principiis quam conclusioni; id est, inmediatius.

\footnotetext{
${ }^{286}$ Non. Falta en el manuscrito.

${ }^{287}$ Ms. $4^{\mathrm{a}}$.
} 
[L.a.26] Nihilominus est ultima conclusio. Quod simpliciter et absolute non potest dici maior postquam utraque est a Deo. Nam quod sit mediatior vel inmediatior parum facit postquam est tam de fide quod ecclesia non potest errare sicut evangelium, licet haeretici negent.

[L.a.27] Et sic habemus quod ecclesia potest condere articulum fidei et obligare nos ad credendum sicut sacrae scripturae. Et non solum ecclesia antiqua apostolorum sed ecclesia quae modo est. Nam in concilio nicaeno iam non erat apostolus, et tantam auctoritatem modo sicut concilium nicaenum.

[L.a.28] Et ad illud verbum Waldensis; scilicet, quod ecclesia iam modo non potest iam condere novos articulos, respondendum est quod intelligitur quia iam non expedit nisi erit necessitas, quia in tanto tempore verisimile est quod omnes sunt iam expliciti, sed non negaret quin si occurrerit necessitas, posset etiam nunc explicare novum articulum.

[L.a.29] [Lectio 13.] Aliud dubium est postquam ecclesia habet auctoritatem condendi articulum fidei, utrum etiam papa solus habeat eandem auctoritatem. Haec quaestio iam est inter retores, nam concedentes quod ecclesia non potest errare, dicunt quod papa potest errare, et licet ecclesia posset explicare tamquam de fide sacram scripturam, non tamen papa. Quidam modernus, Castro, hoc late disputat in suo libro de haeresibus verbo concilium.

[L.a.30] Ratio est quia papa potest esse haereticus, et totum concilium non potest incurrere haeresim. 1tem quia reperiuntur in decretis pontificum aliqua quae non tenentur tamquam de fide sicut alia die citavimus de Innocentio in capitulo gaudemus de divortiis, ubi videtur sentire quod Iacob mentitus est, et quod filii Israel furati sunt sed Deus dispensavit eum illis. Et s. Thomas; imo, Agustinus, tenet oppositum. Imo, aliquando est contradictio inter diversos pontifices, nam Caelestinus papa determinavit quod si alter coniugum incidat in haeresim, quod licet alteri transire ad secunda vota, ut habetur c. quanto de divortiis. Et Innocentius tertius determinavit oppositum, et ita tenetur. Ergo alter illorum erravit.

[L.a.31] Haec quaestio indiget longiore disputatione. Sed pro nunc dicimus primo quod s.Thomas non est sollicitus in praesentiarum facere distinctionem inter papam et concilium, sed satis est quod ecclesia potest determinare articulum fidei. Dicimus secundo quod papa habet eandem auctoritatem condendi articulum sicut concilium, et hoc etiam praetendit s. Thomas ut hic etiam declarat dominus [fol. 67v/296v] Caietanus, etiamsi concilium esset supra papam.

[L.a.32] Primo. Est expressum hoc in illo cap. quoties. 24. q. 1., quod quotiescumque dubium aliquod in fide emerserit, recurrendum est ad Petrum. Et illud quod hic citat s. Thomas: Ego rogaba pro te et tu aliquando conversus confirma fratres tuos. Et certe confirmare fratres est securas facere de dubiis 
fidei. Et illud Ioha. 21. ${ }^{288}$ Pasce oves meas. Et potissimum officium pastoris est instruere in fide. Item quia potestas papae est inmediate a Deo et non ab ecclesia, mirabile est quod dicas: daret illis supremam potestatem in ecclesia et non daret auctoritatem interpretandi scripturam. Et ultimo arguitur, quia papa potest perfecte condere leges in quibus certi sumus quod regitur Spiritu Sancto, nec potest errare. Ergo eadem est ratio de articulis fidei.

[L.a.33] Unde ad primum argumentum in contrario, quod papa potest ese haereticus, concedimus tanquam particularis persona sed non tanquam papa. Volo dicere quod potest habere aliquam haeresis. Tamen non permitteretur determinare illam tanquam de fide credendam populo.

[L.a.34] Et ad 2um. eodem modo respondetur. Quod quando est dissensio inter decreta pontificum, non est dicendum quod aliquid eorum sit determinatum tanquam de fide, quia pontifices aliquando loquuntur tanquam doctores. Et ita Caelestinus non determinavit tanquam de fide quod altero coniugi haeretico liceat alteri transire ad secunda vota, sed dixit tanquam doctor opinionem suam, sicut saepe fecit Innocentius, qui fuit egregius doctor. Caietanus 2. p. apologiae de potestate papae c. 13. egregie et copiosissime tractat hoc argumentum.

[L.a.35] Est tamen hic dubium. Si papa potest facere articulum, quare nunquam fecit ipse solus? Videtur quod nunquam opus esset congregare concilium, et tamen de facto nunquam fecit sine concilio. Respondetur quod papa potest determinare articulum fidei consulendo sacram scripturam et faciendo quod est in se more humano. Aliter errasset sicut concilium ipsum. Et singularis persona in rebus humanis non facit quod in se est nisi consulat viros probos in rebus gravissimis. Et ad consulendo illos expedit facere concilium. Aliter populus scandalizaretur si videret quod papa per se res gravissimas determinaret. Et hoc est quod praetendit hic sanctus Thomas, ut patet in ratione sed contra.

[L.a.36] [Lectio 14.] Ultimum tamen dubium est quid requiratur ad hoc quod aliquid habeatur pro articulo fidei, utrum satis est quod determinetur ab ecclesia vel utrum sufficit quod ecclesia receperit quomodocumque.

Respondetur per propositiones.

[L.a.37] Prima. Non sufficit quod aliquid suscipiatur et approbetur communiter ab ecclesia ut habeatur pro fide. Patet in primis de legendis sanctorum quae publice leguntur, et tamen non habentur pro fide. Imo multae sunt quae utinam essent verae. Item in capite sancta romana approbantur opera Augustini et opera Hieronymi et multa alia, et tamen non sunt de fide. Imo decretum est approbatum ab ecclesia non tanquam de fide ut putant domini

${ }^{288}$ Ms. 20. 
canonistae. Nec habent maiorem auctoritatem opera Augustini quae sunt in decreto quam opera Hieronymi quae non sunt in decreto.

[L.a.38] 2a . Non sufficit quod aliquid sit dubitatum et disputatum in concilio et determinatum ad unam partem ad hoc quod habeatur tanquam de fide. Patet. In cap. maiores de baptismo et eius effectu fuit disputatum et determinatum quod in baptismo infunduntur virtutes; imo videtur determinatum in favorem illorum qui dicunt quod sunt qualitates distinctae. Et tamen non est determinatum tanquam de fide, sed approbatum tanquam verior opinio illorum doctorum.

[L.a.39] $3^{\circ}$. Non sufficit adhuc ad hoc quod sit articulus fidei quod sit determinatum in concilio tanquam de fide, nam in conciliio Carthagi determinatum est quod Christus habuit duas voluntates, et tamen non est articulus fidei. Probatur, quia articulos fidei quilibet tenetur expresse scire, et tamen non est peccatum quod rusticus ignoret quod Christus habuit duas voluntates.

[L.a.40] Sed requiritur ad hoc quod aliquid sit articulus fidei quod sit determinatum et propositum omnibus ad credendum, itaque omnes teneantur scire, sicut sunt articuli qui ponuntur in symbolo apostolorum. Imo proprie loquendo non omnia quae sunt expressa in symbolo nicaeno sunt articuli fidei quamquam sint de fide, sicut est illud quod Spiritus Sanctus procedit a Patre et Filio. Nam rustici hoc ignorantes non peccant.

[L.a.41] Itaque aliud est esse de fide, quod est revelatum pertinens ad religionem et quod si proponeretur alicui ab ecclesia, tenetur credere, sicut est tota sacra scriptura et determinationes conciliorum. Sed ad hoc quod sit articulus requiritur quod sit iam propositum omnibus ad credendum ut omnes teneantur scire.

[L.a.42] Ultima propositio. Non omnia gesta ecclesiae necessarium est ut habeatur tanquam de fide, sicut canonizatio sanctorum. Non est simpliciter de fide quod sanctus qui canonizatur sit sanctus, sed tamen credendum est tanquam certum quia esset maximus error quod ecclesia haberet pro sancto et funderet praeces ad illum qui non est vere sanctus. Et ita esset temerarium et grave peccatum contradicere in hoc ecclesiae. Sed tamen non est de fide, quia illud consistit in quodam ${ }^{289}$ facto.

[L.a.43] Videte quomodo symbolum Athanasii non proprie habet formam symboli sed cuiusdam doctrinae catholicae, et ideo receptum est tamquam regula fidei.

\footnotetext{
${ }^{289}$ Ms. quoddam.
} 
b) Ms. 940

[L.b.1] [fol. 16r] An ad summum pontificem pertineat articulum condere. Respondetur affirmative. Quia editio symboli est determinatio articulorum. Sed facere convenit concilio et congregare concilium pertinet ad Papam. Ergo primum. Item, facere articulum fidei est determinare tanquam de fide aliquam propositionem quae elicitur ex scriptura sacra. Sed ad papam pertinet determinare rem dubiam fidei. Ergo et facere articulos fidei. Vide literam. Et vide lectionem nostram primam de sensibus sacrae scripturae.

[L.b.2] Primo videmus an ad ecclesiam pertineat determinare articulum fidei. Quae quaestio est contra haereticos et catholicos. $1^{\circ}$, Wiclef ${ }^{290}$ (ut recitat Waldensis ${ }^{291}$ to. $1^{\circ}$. lib. 2. cap 19.) dicit quod tota ecclesia non habet auctoritatem determinandi aliquid tanquam de fide nisi expressum sit in sacra scriptura. Sed nos ponimus conclusionem quod conclusio s. Thomae est de fide. Quod ecclesia potest determinare aliquid tamquam de fide. Probatur $1^{\circ}$, quia in concilio nicaeno multa determinata sunt quae antea non tenebantur expresse credere, sicut quod Christus est consubstantialis Patri, etc.

[L.b.3] Item Matth. 28. promisit Christus apostolis clicens: Ego vobiscum sum usque ad consummationem saeculi. Et Ioann. 14: Ego rogaba Patrem et alium paraclytum dabit vobis. Ex quo sumimus argumentum: Christus promisit Spiritum Sanctum, qui permaneret in ecclesia; non videtur ad quid, nisi ut ecclesia non errasset in exponendo sacram scripturam. Ergo.

[L.b.4] Item ratione probatur hoc. Christus nisi mutaret conditionem hominum, non posset ita clare exponere sacram scripturam seu revelare quin manerent multa dubia in diversis hominibus cum conditio humana sit: quot capita, tot sententiae, ut patet quia multi haeretici ex verbis claris eliciunt falsum sensum. Ergo oportet quod maneret in ecclesia auctoritas declarandi dubia et declarandi illa quae sunt fidei determinandi.

[L.b.5] Sed respondent haeretici quod hoc non erat necesarium quia quando erunt dubia, melius esset expectare revelationem a Deo. Sed hoc est intollerabile. Probatur. Nam si esset expectanda revelatio in dubio emergenti, hoc deberet esse quod omnes specialiter haberent revelationem, quod est fatuum et ridiculum. Tamen potest dici ut isti dicunt quod scilicet fieret revelatio [fol. 16v] uni, et ille deberet nuntiare ${ }^{292}$ aliis. Quia vel est de fide quod ille non potest nos decipere vel non, sequitur quod non defficienter provisum est nobis de fide nostra. Si primum dicatis, hoc nos dicimus, quod

\footnotetext{
${ }^{290}$ Ms. Ubicleph.

${ }^{291}$ Ms. Ubaldensis.

${ }^{292}$ Ms. nunciare.
} 
Deus sic ordinavit quod ille esset papa, vel concilium, qui determinaret illa quae sunt fidei.

[L.b.6] 2 um dubium. Quae potestas est ista condendi articulum fidei. Scilicet, an condere articulum sit recipere novam revelationem a Deo inmediate. Respondeo quod non recipit revelationem ecclesia quando condit articulum fidei, sed solum mediate, scilicet habet potestatem eliciendi ex scriptura aliquam propositionem. In hoc consistit auctoritas ecclesiae, quod si scrutetur scripturas ad determinationem articuli non possit errare. Tamen si ecclesia velit ${ }^{293}$ aliquid determinare sine scrutatione scripturae, erraret.

[L.b.7] Sed dicetis. Unde habemus certitudinem quod ecclesia non erravit in determinatione articulorum. Respondetur quod certi sumus ex illo quod Deus promisit quod non deficiet fides ecclesiae. Sed dicetis: ergo nulla est ecclesiae auctoritas, quia quilibet qui fecerit quod in se est et scrutaretur scripturas non permitteretur errare.

[L.b.8] Respondetur quod falsum est; imo, si sancti ita fecissent diligentiam possibilem, si non essent in concilio possent errare, quod non est admittendum de ecclesia cum de fide sit quod ecclesia non potest errare. Habemus ergo quod determinare articulum fidei non est recipere inmediate revelationem a Deo. Sed auctoritas ecclesiae solum est mediate revelatio; id est, per revelationem apostolorum. Ex his sequitur $1^{\circ}$, quod condere articulum fidei non est condere sacram scritpuram. Et sic tota ecclesia non possit condere sacram scripturam cum ad hoc requiratur inmediate revelatio.

[L.b.9] Sed tunc est dubium gravissimum an tanta sic auctoritas ecclesiae sicut sacrae scriplurae et apostolorum . Et videtur quod non, cum scriptura sit per inmediatam revelationem. Respondetur per propositiones. $1^{\mathrm{a}}$ est Abulensis in introductione super [fol. 17r] Matthaeum q. 13. Est ergo conclusio Abulensis quod ecclesia est maioris auctoritatis quam evangelista et quam mille evangelistae. Et probat, quia evangelium non habet auctoritatem a se, quia est Matthaeus, etc., sed habet auctoritatem ab ecclesia; scilicet, quia ecclesia praecipit ut credamus. Ergo si evangelista habet auctoritatem ab ecclesia, ergo maiorem auctoritatem habet ecclesia quam evangelista. Item, ex illo Augustini: evangelio non crederem nisi auctoritas, etc.

[L.b.10] Alia est opinio Caielani in tractatu de auctoritate papae et concilii cap. 4., ubi dicit quod evangelista in his quae sunt fidei est maioris auctoritatis quam ecclesia.

[L.b.11] $3^{\text {a }}$ opinio est Driedonis lib. de ecclesiasticis scripturis, cap. 4. Dicit quod ecclesia capitur dupliciter. Uno modo pro tota ecclesia ${ }^{294}$ a tempore

\footnotetext{
${ }^{293}$ Ms. vellit.

${ }^{294}$ Palabra tachada: et.
} 
apostolorum usque ad nos includendo apostolos. Et isto modo dicit: tanta est auctoritas ecclesiae quanta scripturae. Quod patet, quia scriptura est verba apostolorum et testimonia illorum. Ergo. Item quia dato nulla ${ }^{295}$ fuisset scriptura sacra tantae auctoritatis esset in dictis apostolorum sicut in scriptura sacra.

[L.b.12] $2^{\circ}$ modo accipitur ecclesia pro collectione fidelium post tempus apostolorum seclusis apostolis. Tunc est conclusio. Ecclesia non est tantae auctoritatis sicut sacra scriptura. Quod probatur quia isto modo ecclesia non potest condere scripturam. Ergo non est tantae auctoritatis sicut sacra scriptura, neque sicut apostoli. Ergo. Pono 5. conclusiones de ista materia.

[L.b.13] $1^{\text {a }}$ conclusio. Comparare ecclesiam ad scripturam concludendo apostolos in ecclesia est comparare idem ad ipsum. Et nulla est comparatio, quia comparatio debeat esse inter duo. Et probatur quia comparare scripturam ad apostolos est comparare apostolos ad suam assertionem, quae solum habet auctoritatem ipsius asserentis. Quando ergo fit comparatio ecclesiae ad scripturam debet accipi ecclesia seclusis apostolis.

[L.b.14] Et confirmatur hoc quia comparare ecclesiam ad scripturas est comparare ecclesiam ad apostolos. Item quia differentia inter apostolos et ecclesiam est quia ecclesia non potest facere scripturam. Bene tamen apostoli. Ergo quando comparamus scripturam et ecclesiam, comparamus ecclesiam quae non potest condere scripturam.

[L.b.15] [fol. 17v] $2^{\mathrm{a}}$ conclusio. Accipiendo ecclesiam seclusis apostolis non est substentabilis opinio Abulensis. Nec sat est dicere quod Abulensis non cepit isto modo ecclesiam, quia ipse se exponit cum compararet ecclesiam ad apostolos. Et sic pono conclusionem, quod nullo modo ecclesia isto modo est maioris auctoritatis quam scriptura, neque angelus nec ipse Deus.

[L.b.16] Probatur. Quia scriptura est testimonium Dei et assertio Dei. Ergo scriptura est tantae auctoritatis asssertio Dei sicut ipse Deus. Hoc expresse voluit significare Christus Matth. 24, caelum et terra transibunt, verba autem mea non transibunt. Idem apostolus ad Gal. $1^{\circ}$. Si nos vel angelus de caelo aliud vobis evangelizaverit quam quod nos evangelizavimus, anathema. Ergo. Etiam si apostoli dicerent modo quod Christus non est Deus, non deberemos credere illis, etiamsi modo Deus illud diceret.

[L.b.17] Et ad argumentum Abulensis: evangelistae habent auctoritatem ab ecclesia, ergo, respondetur negando antecedens quia ego non credo evangelistae quia ecclesia dicit, sed quia Deus dicit. Et si arguas: ego non crederem evangelio Ioannis nisi quia ecclesia dicit evangelium esse Ioannis, concedo. Ergo Ioannes habet auctoritatem ab ecclesia, nego consequentiam,

295 Tachado: esset scriptura. 
quia solum facit quod ego credam hoc esse evangelium Ioannis. Sed postquam hoc credo, etiamsi ecclesia diceret quod illud quod dicit Ioannes est falsum, non crederem.

[L.b.18] Est exemplum clarum. Si esset papa coram me quem ego non cognosco et aliquis plebeius homo dicat quod hic est papa, postquam ego credo illi quod est papa, si papa aliquid mihi dicit, non credo illi propter auctoritatem alterius, sed propter ipsum papam credo. Eodem modo dico de evangelio et ecclesia. Et hic est sensus illiud dicti Augustini; scilicet, evangelio non crederem nisi ecclesia me compelleret credere esse evangelium. Sed sit argumentum de $\mathrm{e}^{296}$ epistolae Iudae, ubi citatur librum Enoch, qui liber non recipitur ab ecclesia tanquam canonicus. Ergo magis credimus ${ }^{297}$ ecclesiae dicenti quod non canonicus ille liber [fol. 18r] quam apostolo oppositum dicenti. Respondetur, quod ex hoc quod apostolus citet illum librum non sequitur quod ille habeatur tanquam canonicus apud apostolum, sed illum dictum erit iam canonicum.

[L.b.19] Sed est dubium e contra an sacra scriptura et apostoli sint maioris auctoritatis quam ecclesia accipiendo ecclesiam seclusis apostolis, ut vult Caietanus. Sit de hoc $3^{\text {a }}$ conclusio. Utraque auctoritas est divina, scilicet ecclesiae et scripturae dato quod auctoritas scripturae sit inmediatior quam ecclesiae. Quia ecclesia nititur in sacra scriptura in suis determinationbus, sequitur ex hac conclusione quod eadem species haeresis est negare auctoritatem ecclesiae et scripturae. Probatur, quia utraque est auctoritas divina quamquam gravius peccatum esset in eadem specie negare propositionem evangelii quam auctoritatem seu determinationem ecclesiae.

[L.b.20] $4^{\text {a }}$ conclusio. Auctoritas scripturae et apostolorum potest aliquo modo dici maior quam auctorilas ecclesiae; id est, inmediatior, sicut dicit Aristoteles; propter unumquodque tale, etc.

[L.b.21] Ultima conclusio. Quod simpliciter loquendo et absolute non dicitur maior auctoritas scripturae quam ecclesiae. Sed sunt aequalis auctoritatis, quia ambae auctoritates sunt a Deo. Ex quo sequitur quod tantae auctoritatis est ecclesia quae modo est sicut ecclesia antiqua in qua fuerunt apostoli; id est, tam digna fidei sicut alia. Quod corollarium est contra Driedonem. Et etiam contra Durandum in 3. d. 24. q. 1., qui dicit quod ista ecclesia non est tantae auctoritatis sicut ecclesia antiqua.

[L.b.22] Probatur, quia in concilio nicaeno nullus erat apostolus et tamen habentur tanquam de fide illa quae ibi determinata sunt. Et ecclesia quae nunc est tantae auctoritatis est sicut ecclesia quae tunc erat. Ergo. Hoc corollarium

\footnotetext{
${ }^{296}$ Letra tachada.

${ }^{297}$ Palabra tachada.
} 
est contra Driedonem et contra Durandum in 3. d. 24. q. 1. tenentes quod ecclesia antiqua fuit maioris auctoritatis quam ecclesia quae nunc est, unde verbum illud Augustini: evangelio non crederem nisi ecclesiae auctoritas me compelleret, intelligitur de ecclesia quae erat tempore Augustini, non tempore apostolorum, ut Durandus dicit. Et sic potest intelligi de ecclesia quae nunc ${ }^{298}$ [fol. 18v] est.

[L.b.23] Probatur hoc, quia si ecclesia quae nunc est non fuisset tantae auctoritatis sicut ecclesia antiqua, non sufficienter esset provisum ecclesiae. Dato enim in ecclesia apostolorum esset determinatum hoc ex evangelio Ioannis et reliquissent signatum suis nominibus, non possemus esse certi hoc esse evangelium Ioannis magis quam de scripto Titolivii, nisi ecclesia praesens hanc haberet auctoritatem determinandi hoc esse evangelium Ioannis.

[L.b.24] Sed contra hoc est auctoritas Waldensis tamo 1. lib. 2. cap. 22., ubi dicit quod ecclesia potest determinare aliquid tanquam de fide, ut patet in concilio nicaeno. Et loquitur de ecclesia seclusis apostolis. Sed addit: Iam modo ecclesia non potest determinare, quia iam venit ad perfectum numerum articulorum. Sicut homo, usque ad 30. annos potest crescere, non tamen ultra postquam pervenit ad plenitudinem entis. Respondetur quod Waldensis intelligit quod non est necessarium amplius determinare articulos fidei, non quod ecclesia sit minoris auctoritatis quam antigua. Si enim opus esset determinare articulum fidei, haec ecclesia quae una est posset.

[L.b.25] Notandum tamen quod non dicimus quod haec ecclesia est tantae auctoritatis et potestatis sicut ecclesia antiqua cum apostolis. Quia illa poterat condere sacram scripturam, quod ista non potest. Sed dico quod est tantae auctoritatis; id est, tam digna ut ei adhibeatur fides sicut antiquae ecclesiae. Sed iam est quaestio an solus papa possit condere articulum fidei sine concilio. Et S. Thomas videtur hic dicere quod sic. Et haec quaestio est iam inter catholicos et sine disputatione dicam aliqua de hoc. Videte fratrem Alphonsum de Castro in verbo concilium lib. de haeresibus.

[L.b.26] Et omnes quotquot sunt tenentes quod concilium est supra papam tenent quod papa solus non potest determinare articulum fidei, sed solum concilium potest. Probant duabus rationibus. $1^{\text {a }}$. Quia papa potest errare in his quae sunt fidei, et concilium, non. Ergo papa non potest determinare articulum fidei. [fol. 19r] Antecedens probatur quia papa potest esse haereticus.

[L.b.27] $2^{\mathrm{a}}$ ratio est quia determinationes pontificum non habentur tanquam de fide, ut patet in cap. gaudemus de divortiis, ubi dicit Innocentius quod Iacob mentitus est. Et oppositum tenet Augustinus. Est opinio multorum. Et in

${ }^{298}$ Palabra tachada. 
cap. quando de divortiis Innocentius cognoscit ${ }^{299}$ determinationem Caelestini, quod scilicet quando alter coniugum incidit in haeresim, alter potest transire ad secundas nuptias. Sed Innocentius reprobat illud et dicit quod non licet.

[L.b.28] Nos ponimus conclusiones de hoc. $1^{\text {a }}$ conclusio. S. Thomas non intendit hic disputare an papa sit upra concilium quia tempore suo quaestio haec non erat celebris sicut nunc.

[L.b.29] $2^{\text {a }}$ conclusio. S. Thomas intelligit quod papa solus potest determinare articulum fidei. Et probatur $1^{\circ}$ auctoritate ex illo cap. quotiens. 24. q. 1. Item probatur ex illo dicto Dornini: Tu aliquando conversus confirma fratres tuos. Et non videtur quomodo debuit confirmare nisi declarando et determinando illa quae sunt fidei. Item ex illo: Pasce oves meas. Non enim posset pascere nisi haberetur auctoritas determinandi illa quae sunt fidei et deberent credi. Item de fide est quod papa non potest errare in his quae pertinent ad mores. Ita, nec in his quae pertinent ad fidem. Quia Christus dixit Petro: Ego rogavi pro te ut, etc. Item quia auctoritas papae non est a concilio, sed inmediate a Deo. Ergo potest facere articulum fidei.

[L.b.30] Ad argumenta in contrarium respondetur. Ad 1um. Distinguimos quod papa potest errare in his quae sunt fidei; scilicet tanquam particularis persona, et sic concedo, vel tanquam papa, et sic negamus. Quod est dicere quod potest habere aliquam haeresim. Tamen nunquam permittet Deus ut illam proponat tanquam de fide. Probatur haec solutio. Quia ipsi admittunt quod papa in his quae pertinent ad mores et ad gubemationem ecclesiae non potest errare in condendis legibus licet possit esse peccator [fol. 19v] in particulari.

[L.b.31] Ad 2um. dicimus quod in illis capitibus non determinat tanquam pontifex, sed tanquam doctor. Et ad illud quod sunt dissensiones inter ${ }^{300}$ determinationes pontificum optime respondet Caietanus in 2. p. apologiae papae cap. 14., ubi dicit quod ubi sunt tales dissensiones nunquam determinatur tanquam a pontifice.

[L.b .32] Sed posset esse argumentum contra nos, quia si papa hoc posset, aliquando fecisset. Sed nunquam fecit. Ergo. Respondetur quod papa nisi faceret quod in se est scrutando scripturas, posset errare sicut et ipsum concilium nisi hoc etiam fecisset. Et ideo oportet consulere sapientes viros et legis peritos. Et ideo male faceret nisi congregaret ad determinandum aliquid tamquam de fide licet per se facere posset.

[L.b.33] Quaeritur quid requiratur ad hoc quod aliquid habeatur tanquam de fide vel tanquam articulus fidei. Respondetur per propositiones. $1^{a}$. Ad hoc quod aliquid sit articulus fidei non sufficit quod recipiatur ab ecclesia, ut patet

\footnotetext{
${ }^{299}$ Cognoscit. Falta en el manuscrito. Si se coloca es en orden a que la frase haga sentido.

${ }^{300}$ Letra tachada.
} 
in legendis sanctorum; imo, in catholica et romana ecclesia recipiuntur opera Hieronymi, Augustini. Tamen non recipiuntur tanquam de fide. Nec etiam illa quae continentur in decreto et dictis istorum doctorum. Quod ponimus contra canonistas hoc dicentes.

[L.b.34] $2^{\mathrm{a}}$ propositio. Adhuc non sufficit quod aliquid sit disputatum in concilio et sit determinatum in unam partem ad hoc quod sit articulus fidei, ut in cap. maiores de baptismo et eius effectu, ubi determinatur quod infunduntur virtutes in baptismo licet non sint tanquam de fide ponendae.

[L.b.35] $3^{\text {a }}$ propositio. Non sufficit ut sit articulus fidei aliqua propositio quod determinetur tanquam de fide. Pro quo notate quod est differentia inter propositionem de fide et articulum de fide. Quia propositio de fide est propositio revelata pertinens ad religionem quam negare esset haereticum, [fol. 20r] sicut omnis propositio quae est in sacra scriptura. Eodem modo determinationes conciliorum.

[L.b.36] Sed est dubium, quia determinatio concilii non est revelata. Respondetur quod dicitur revelata quia illa est revelata quae infertur ex sacra scriptura. Sed articulus fidei est propositio determinata tanquam de fide quam omnes tenentur credere et proponitur ab ecclesia tanquam de fide ut $a b$ omnibus credatur; imo, addo quod, etiamsi contineatur in concilio nicaeno, non sufficit ut sit articulus fidei nisi proponatur.

[L.b.37] $4^{\mathrm{a}}$ conclusio. Gesta et acta ecclesiae non est necesse quodhabeantur omnia tanquam de fide sicut canonizare sanctos, quia hoc consistit inquodam facto. Sed nihilominus illud tenendum est tanquam certissimum licetnon tamquam de fide. Et ratio quare tenendum est certissima est, quia essetgravis error si ecclesia haberet aliquem pro sancto qui non est. 